九州大学学術情報リポジトリ

Kyushu University Institutional Repository

\title{
On the bionomics of Itoplectis narangae (Ashmead) : (Ichneumonidae, Hymenoptera)
}

Shin, Yoo-Hang

Kyunghee University

Yasumatsu, Keizo

Entomological Laboratory, Department of Agriculture, Kyushu University

https://doi.org/10.5109/22798

出版情報 : 九州大学大学院農学研究院紀要. 16 (1)，pp.1-75, 1970-01. Kyushu University バージョン：

権利関係 : 
Journal of the Faculty of Agriculture, Kyushu University, Vol. 16, No. 1 January 20, 1970

\section{On the bionomics of Itoplectis narangae (Ashmead) (Ichneumonidae, Hymenoptera)*}

\section{Yoo-Hang SHIN and Keizo YASUMATSU}

\begin{tabular}{|c|c|}
\hline I & 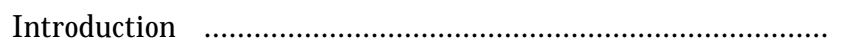 \\
\hline II & Historical review \\
\hline III & 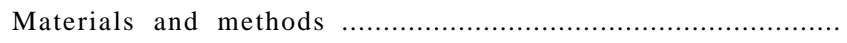 \\
\hline IV & Field observation \\
\hline $\mathrm{V}$ & 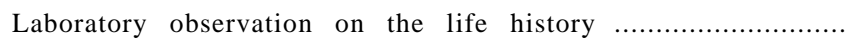 \\
\hline VI & 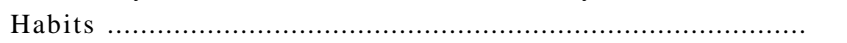 \\
\hline VII & Reproductive capacity \\
\hline VIII & $\begin{array}{l}\text { Effect of the period of lacking hosts on the number of eggs } \\
\text { deposited }\end{array}$ \\
\hline IX & Longevity of adult \\
\hline $\mathrm{X}$ & Factors affecting the size of this species \\
\hline XI & $\begin{array}{l}\text { Morphological comparison between the specimens of Itoplec- } \\
\text { tis narangae collected in the paddy field and those obtained } \\
\text { from the materials emerged from Galleria mellonella pupa } \\
\text { in the laboratory }\end{array}$ \\
\hline XII & $\begin{array}{l}\text { Effect of some insecticides on the adult and immature stages } \\
\text { of Itoplectis narangae }\end{array}$ \\
\hline XIII & Approach to the mass production \\
\hline XIV & 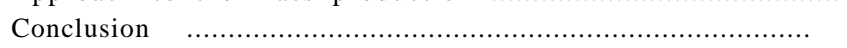 \\
\hline $\mathrm{x} v$ & Summary \\
\hline XVI & Acknowledgement \\
\hline KVII & References ….......................... \\
\hline
\end{tabular}

\section{Introduction}

An ichneumon fly, Itoplectis narangae (Ashme:d) is widely distributed all over Japan, Korea, Taiwan, the Philippines the Kuriles, Hawaii, Okinawa, Mexico, the Ryukyus, Sakhalin and Ch'na proper in the Paci-

* Contribution Ser. 2, No. 312, Entomological Laboratory, Kyushu University. Special Project Research supported by the Ministry of Education "Studies on the Dynamic Status of Biosphere." This study was carried out as part of JIBP. 
fic area. This species has long been known to be a parasite of the larvae and pupae of major insect pests which usually attack rice plants. However, no one has so far studied the bionomics of this species. Aside from the description of a new taxon, most of the accounts in the literature concerning this species deal with host-parasite relations.

The present paper is the outcome of the author's two years study on the bionomics and the mass production of this species for the future use as a controlling agent against the major rice pests.

\section{Historical review}

Itoplectis narangae was first described by Ashmead (1906) as a new species under a new genus, Nesopimpla naranyae, based on the adult emerged from the larva of Naranga aenescens Moore by Matsumura. Thereafter, Nesopimpla was synonymized under the genus Itoplectis by Townes (1940). Watanabe (1966) claimed that the species name narangae should be used instead of naranyae due to an careless error of the original spelling with a view that it was first described as a parasite of the host Naranga aenescens.

Ashmead (1906), Cushman (1922), Kuwayama (1928), Ozaki (1938), Yasumatsu and Fukushima (1945) reported that the species is parasitic on the larva of Naranga aenescens. U. Nawa (1912), Y. Nawa (1913), Cushman (1922) and Chéng (1935) also reported that it is a parasite of the pupa of Naranga aenescens. In addition, U. Nawa (1912), Y. Nawa (1913), Sonan (1930) and Minamikawa (1953) discovered that it is parasitic on the larva and pupa of Sesamia inferens Walker. Kuwayama (1932) reported that it parasitizes the larva and pupa of Oulema oryzae (Kuwayama). This is the first record of this species from the Coleopterous larva and pupa besides the Lepidopterous larva and pupa.

Sakai et al. (1941) observed that this species is parasitic on the larva and pupa of Cnaphalocrocis medinalis Guénée and Kamiya (1941) reared this species from the pupa of Adoxophyes orana Fisher von Röslerstamm. Sonan (1930) confirmed the emergence of this species from the larvae of Homona coffearia Nietner and Borbocinnara Wallace in Taiwan.

Y. Nawa (1913) reported that this species is a parasite of the pupa of Chilo suppressalis Walker. Although Zwaluwenberg (1929) and Watanabe (1966) also wrote that it is a parasite of Chilo suppressalis, they did not indicate the parasitized stage of the host. Hidaka (1965) observed that this parasite is parasitic on the larva of Chilo suppressalis. Yasumatsu (1967) recorded it as a parasite of pupa of Chilo suppressalis and the occurrence of the species in the Philippines. 
In his paper on the ecological observation of Naranga aenescens, Ozaki (1938) reported that the percentage parasitism of this species was 9.1. This is the first record of the species on its field activity.

Iwata (1960) dealt with this species in his study on the comparative anatomy of the ovary of Hymenoptera. In his study carried out in the truck crop field at Hakozaki, Fukuoka city, Hirose (1966) put on record this species in the list of carrot flower visiting parasitic Hymenoptera. $\mathrm{Wu}$ (1967) recorded it as a secondary parasite of Diadromus sp.

\section{Materials and methods}

Field studies were carried out mainly in the paddy field of Hakozaki, Fukuoka city and its vicinity from September 1967 through the end of 1968.

Laboratory experiments were conducted mainly in a $25^{\circ} \mathrm{C}$ insectary together with the phytotron and incubator if necessary. The parasites used for the experiments were those collected from the paddy field and reared continuously with the pupae of Galleria mellonella (Linné) as an alternate host in the insectary. Two petri dishes were used as an oviposition unit of the parasites with an improved sandwich method (B. R. Subba Rao, 1955) as illustrated in Fig. 1. The open sides of the petri dishes were covered with gauze and tied up with rubber bands. The para-

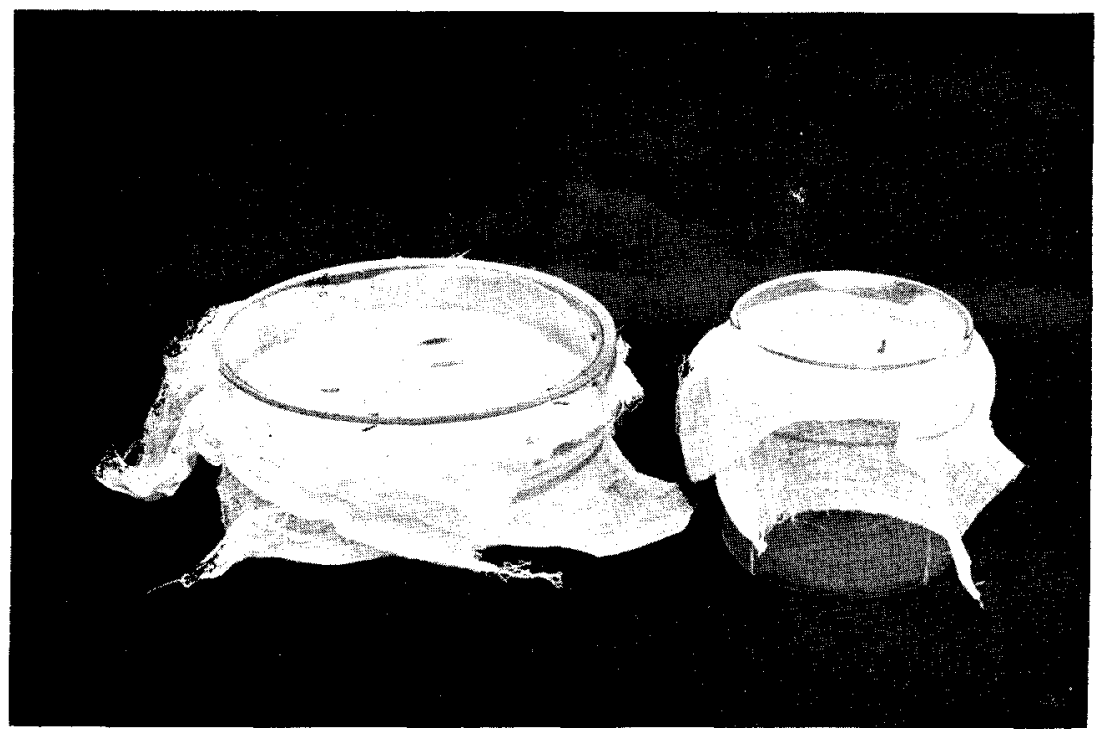

Fig. 3. Containers. Right: Container A, Left : Container B. 
sites were kept on the upper dish and fed with undiluted honey and water which was absorbed in cotton, and a small amount of water was kept in the lower dish so as to maintain a constant humidity in the dishes. The author used two kinds of such containers (petri dishes) for the present experiments; in the case of the first containers the upper one was $9.5 \mathrm{~cm}$ in diameter and $2.0 \mathrm{~cm}$ in height, the lower one was 8.7 $\mathrm{cm}$ in diameter and $9.0 \mathrm{~cm}$ in height (hereafter this is referred as Container A) ; in the second ones, the upper one was $16.2 \mathrm{~cm}$ in diameter and $3.2 \mathrm{~cm}$ in height, the lower one was $15.4 \mathrm{~cm}$ in diameter and 3.5 $\mathrm{cm}$ in height (hereafter this is referred as Container B). The size of adult parasites used was controlled properly in accordance with the size of host pupae.

The methods applied in the present experiments are given in detail in each section of this paper.

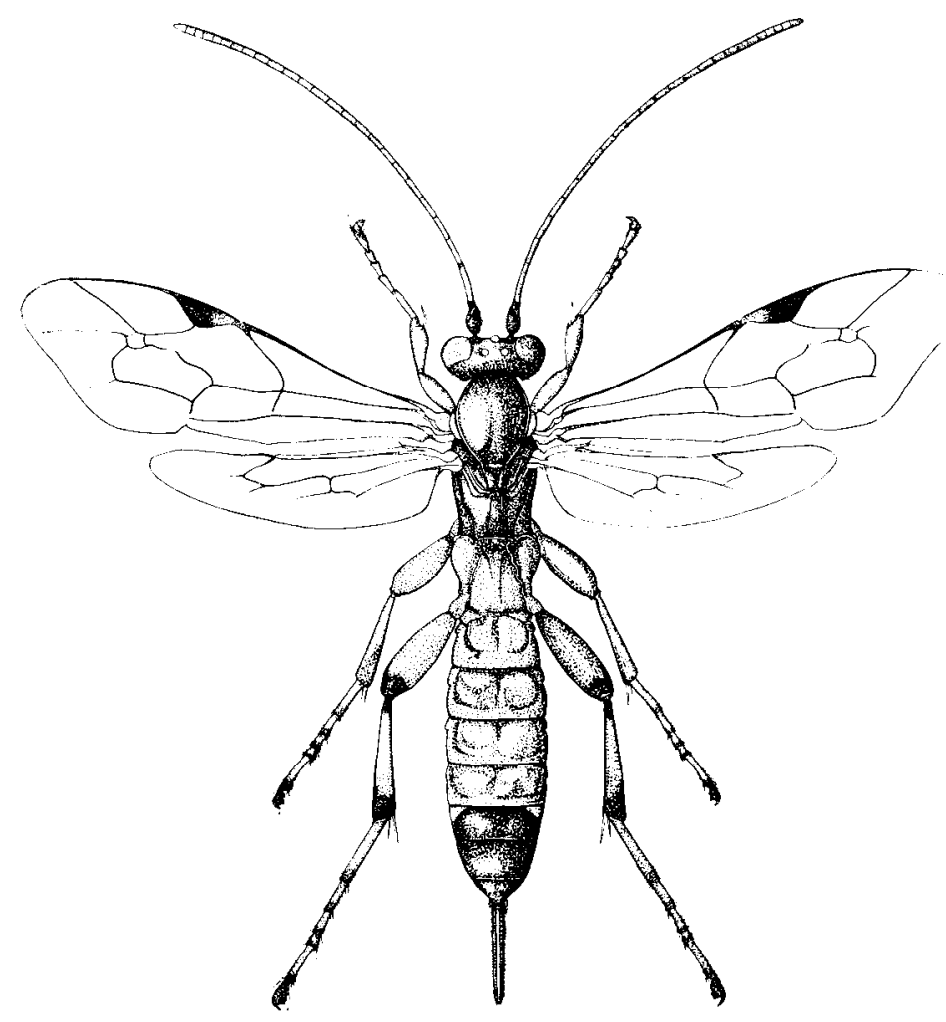

Fig. 2. Itoplectis narangae (Ashmead)( 우). (Drawn by Miss M. Honda) 


\section{Field observation}

Investigation on the field activity of this species was carried out in the paddy field of Fukuoka and its vicinity for the period from September, 1967 to the end of 1968.

\section{Seasonal fluctuation.}

This species was collected for approximately an hour at certain paddy field by a regular sweeping method in order to investigate the seasonal fluctuation during the period from the middle of May to the first part of December, and the results are given in Fig. 3. As seen superficially from Fig. 3, the appearance of the adults was observed three times a year.

The first appearance occurred between the middle of May and the early part of July, and the middle of June was the peak of its emergence. The middle and later parts of May when the first appearance began coincided with the blooming period of milk vetch, Astragalus sinicus Linné in the paddy field. The emerged parasites were seen commonly on the stack, ridge and around the weeds of the ditch side surrounding the paddy field. The transplanting of rice plants was not done until the middle of June. Therefore, during this period the parasite might be searching for the host pupae of the other insect pests infesting the plants other than rice. The second appearance began from the later part of July and continued until the middle of August. Almost no field activity of this species was observed during the period from the later

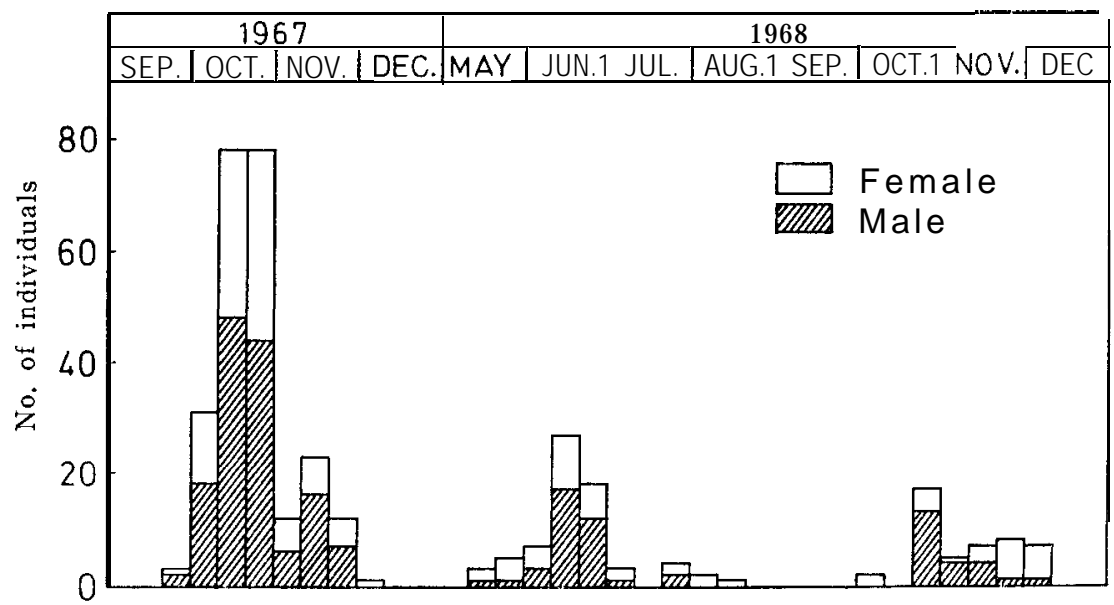

Fig. 3. The seasonal fluctuation of the number of both sexes of Itoplectis narangae collected in the field. 
part of August to the middle of September. However, it is not clear whether this may be attributable to 1) the difficulty of collection due to small number of individuals, 2) the host relations or 3) the insecticidal application or other artificial factors. The third occurrence was observed from the middle of September until early December with a peak in the middle and later part of October. It is felt, however, that two or three generations might have passed during this period. It is thought that some of the offspring emerged in the later part of October, probably some in the middle of November, but some went to hibernation in the larval stage. The harvest of the paddy field began from early November and ended in the middle of the same month.

This species was observed searching for the hosts until early December on and between the stack in the sun, stubble and straw spreading over the field after the harvest. During this period the author observed that this species was caught in the web of a spider, Neoscona doenitzi (Boesenberg et Strand) around the stack.

\section{Hibernation.}

This species in its natural environment passes through the winter in the final instar larval stage within the body of its host pupa. It is presumed, therefore, that the place of hibernation is the stubble and stack of rice plant or the paddy field as in case of the host.

Fourty-two pupae of Cnaphalocrocis medinalis hibernating on the stubble and field surface were collected in the paddy field of Hakozaki, Fukuoka on January 11, 1968. Three final inrtar larvae of this species were found among these pupae.

3. Relationship between the height above the ground of the pupation site of the host and parasitism.

The outbreak of Cnaphalocrocis medinalis was observed throughout the western part of Japan in 1967 and the damage was severe in the rice plant. Of course the paddy field of Hakozaki where the field investigation has been made was not exceptional and relatively large numbers of this species were observed by the author.

According to Sakai et al. (1941) the pupation site of C. medinalis is seen commonly at $9-12 \mathrm{~cm}$ above the ground in the case of rice plant. During the field investigation the pupae were found between the leaf sheath and culm or within the rolled leaf located both above and below the level of $12 \mathrm{~cm}$ above the ground.

In order to elucidate the relationship between the pupa of $\mathrm{C}$. medinalis and the parasite activity at each different height of the place of pupation, investigation was conducted on 388 hills of rice plant (about 75 
$\mathrm{cm}$ in height) for four days from November 1 through 4, 1967 in the paddy field where there was a high possibility of collecting as many parasites as possible by the sweeping method.

The pupae and casted pupae of C. medinalis which were attached to the stems were collected from different height above the ground for the purpose of obtaining the percentage of parasitism by Itoplectis narangae at the corresponding height.

The result of this investigation is shown as in Tables 1 and 2 and Fig. 4.

Ichneumon fly, Coccygomimus nipponicus (Uchida) was rarely reared from the pupae of $\mathrm{C}$. medinalis in the paddy field, but the percentage of parasitism by this parasite was very low or almost negligible. Actually, only two adults of this parasite were reared from the field collected material from September through December, 1967. Therefore, the presence of Coccygomimus nipponicus does not give any actual influence on the percentage parasitism of $\mathrm{C}$. medinalis by Itoplectis narangae.

As seen clearly from Table 1 , the pupation site of C. medinalis occupies $69 \%$ of the total number of pupae collected at less than $15 \mathrm{~cm}$ above the ground. However, the casted pupae located in such height have never been parasitized by this Ichneumon fly. Only the casted pupae located higher than $16 \mathrm{~cm}$ above the ground were observed to be parasitized, the highest value of parasitization having been 75 \% in the

Table 3. Relation between heights of the pupation site of Cnaphalocrocis medinalis above the ground and number of casted pupa, the contents of which were devoured by the larva of Itoplectis nurangae (1967).

\begin{tabular}{cccc}
\hline $\begin{array}{c}\text { Height above } \\
\text { the ground } \\
\text { (in cm) }\end{array}$ & $\begin{array}{c}\text { No. of casted } \\
\text { pupae } \\
\text { collected }\end{array}$ & $\begin{array}{c}\text { No. oîcasted pupae } \\
\text { showing the trace } \\
\text { of parasitization }\end{array}$ & $\begin{array}{c}\text { Percentage } \\
\text { parasitism }\end{array}$ \\
\hline $1-10$ & 139 & & \\
$11-15$ & 70 & & 7.7 \\
$16-20$ & 26 & 2 & 71.3 \\
$21-25$ & 21 & 15 & 72.7 \\
$26-30$ & 11 & 8 & 87.5 \\
$31-35$ & 8 & 7 & 100.0 \\
$36-40$ & 7 & 7 & 57.1 \\
$41-45$ & 7 & 1 & \\
$46-50$ & 2 & & \\
$51-55$ & 2 & & \\
$56-60$ & 1 & 44 & \\
\hline
\end{tabular}


Table 2. Relation between heights of the pupation site of Cnaphalocrocis medinalis above the ground and number of pupae parasitized by Itoplectis narangae (1967).

\begin{tabular}{rrrr}
\hline $\begin{array}{l}\text { Height above the } \\
\text { ground (in cm) }\end{array}$ & $\begin{array}{c}\text { No. of pupae } \\
\text { collected }\end{array}$ & $\begin{array}{c}\text { No. of pupae } \\
\text { parasitized }\end{array}$ & $\begin{array}{c}\text { Percentage } \\
\text { parasitism }\end{array}$ \\
\hline $1-10$ & 86 & & \\
$11-15$ & 44 & & \\
$16-20$ & 20 & 1 & 50.0 \\
$21-25$ & 1 & 2 & 50.0 \\
$26-30$ & 2 & & 50.0 \\
$31-35$ & 4 & 1 & \\
$36-40$ & 2 & & \\
$41-45$ & 2 & & \\
$4-50$ & 2 & & \\
$51-55$ & 2 & 4 & \\
$56-60$ & 2 & & \\
\hline Total & 167 & & \\
\hline
\end{tabular}

pupae located between $21 \mathrm{~cm}$ and $50 \mathrm{~cm}$ in height above the ground. This may indicate that the searching activity or zone of this parasite is limited to the height of more than $16 \mathrm{~cm}$ above the ground and below this height the host pupae are quite free from the attack of the parasite. In the laboratory, this parasite attacks the pupae of Cirphis unipuncta Haworth readily, but entirely not in the field. The reason is the same as the case of C. medinalis and the pupae of Cirphis unipuncta are always found at the sites below $15 \mathrm{~cm}$ above the ground. The oviposition of this species on the pupae of C. medinalis on stubble could be observed from the middle of November after the harvest season. This phenomenon is sufficient enough to suggest the characteristic of searching behavior of this species.

Flanders (1947) points out that for parasite females the power to occupy host-inhabited areas is an attribute which constitutes the elements of the power of host discovery and that it depends on the responses of the female parasite to such factors as plant surfaces, odors, air movement, light, temperature and humidity. As Flanders pointed out, the microclimate of paddy field and the reaction of positive phototaxis of this species along with the growth of rice plant are considered to be the primary factors of its failure to search its hosts which are locating as deep as the lower part of rice plant. It is felt necessary to carry out further field studies and laboratory experiments on such problems in the future.

The ovipositional behavior of this species as described above is also 


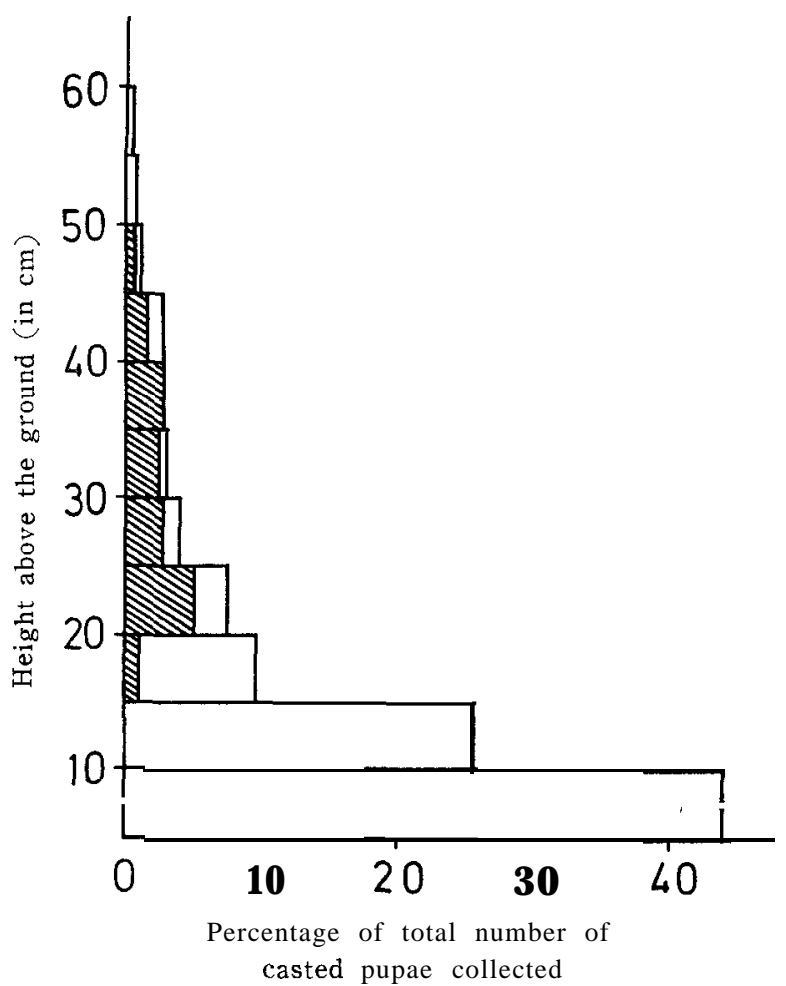

Fig. 4. Parasitization by Itoplectis narangae of the pupae of Cnaphalocrocis medinalis at different heights above the ground. The data based on the collection of Nov. 1-4. Slantly hatched area represents the percentage parasitism.

considered to be one of the major factors that lower the percentage parasitism, as a whole, of $C$. medinalis on the growing rice plant.

\section{Laboratory observation on the life history}

\section{Descriptions of the immature stages and developmental period.}

The developmental period of a parasite is one of the most important factors in evaluating its effectiveness in biological control. The author investigated the developmental period of this species and observed its immature stages.

Method: The pupa of Galleria mellonella was exposed for an hour to this species in a $25^{\circ} \mathrm{C}$ insectary for oviposition. Several host pupae 
which were oviposited by the parasite were dissected in water every day, and the shape of egg and the larvae were investigated. Spiracle was also investigated in a manner similar to that used by Finlayson (1960) ; the cast larval skins were removed from the host pupa and softened by soaking in 10 percent potassium hydroxide at room temperature for several hours. Then the skin was washed in water, immersed for 30 seconds in a weak solution of carbolfuchsin stain, washed again in water, sealed with Faure's solution and mounted on a microscope slide.

The terminology used in the description of the larval instars is that of Short (1959).

\section{1) Descriptions of immature stages.}

The eggs laid in the host pupa and full-grown larva in each instar were measured, and the results of which are given in Table 3.

It may be seen from Table 3 that the size of larvae after the fifth instar is strongly influenced by the size of the pupae of Galleria mellonella provided. Each instar larva except for the cephalic structure is readily discriminated by the width of head capsule.

Table 3. The measurement in millimeters of eggs, larvae and pupae of Itoplectis narangae reared on Galleria mellonella.

\begin{tabular}{lcccc}
\hline $\begin{array}{l}\text { Stages or } \\
\text { instar }\end{array}$ & $\begin{array}{c}\text { No. of } \\
\text { individuals } \\
\text { measured }\end{array}$ & $\begin{array}{c}\text { Average length } \\
\text { and S. E. }\end{array}$ & $\begin{array}{c}\text { Average width and S. E. } \\
\text { Widest point Head capsule }\end{array}$ \\
\hline Egg & 20 & $1.34 \pm 0.02$ & $0.23 \pm 0.02$ & \\
First instar & 20 & $2.05 \pm 0.17$ & $0.51 \pm 0.03$ & $0.23 \pm 0.02$ \\
Second instar & 20 & $2.85 \pm 0.29$ & $0.78 \pm 0.09$ & $0.34 \pm 0.02$ \\
Third instar & 20 & $3.89 \pm 0.49$ & $1.23 \pm 0.25$ & $0.19 \pm 0.03$ \\
Fourth instar & 20 & $6.41 \pm 0.36$ & $2.08 \pm 0.24$ & $0.69 \pm 0.0 \pm$ \\
Fifth instar & 20 & $9.72 \pm 1.23$ & $3.04 \pm 0.42$ & $0.95 \pm 0.05$ \\
Prepupa & 20 & $9.08 \pm 1.29$ & $2.64 \pm 0.62$ & \\
Pupa & 20 & $10.43 \pm 0.69$ & $2.57 \pm 0.36$ & \\
& 20 & $10.19 \pm 1.19$ & $2.48 \pm 0.67$ & \\
\hline
\end{tabular}

Egg (Fig. 5, A) : smooth, shinning, pearly-white in color and elongateoval in shape. Anterior end more bluntly rounded than posterior end.

First instar larva (Fig. 5, B, C and D) : spindle-shaped with 13 body segments. Head well defined and somewhat quadrate in outline. Each segment on both sides of dorsal line from the third metathorax to the eighth abdominal segment is protruded like tubercle, remarkable immediately after hatching but becomes blunt slightly at the end of the insta1. Mandible (Fig. 5, D) long and sharp, distinctly curved posteriorly. 


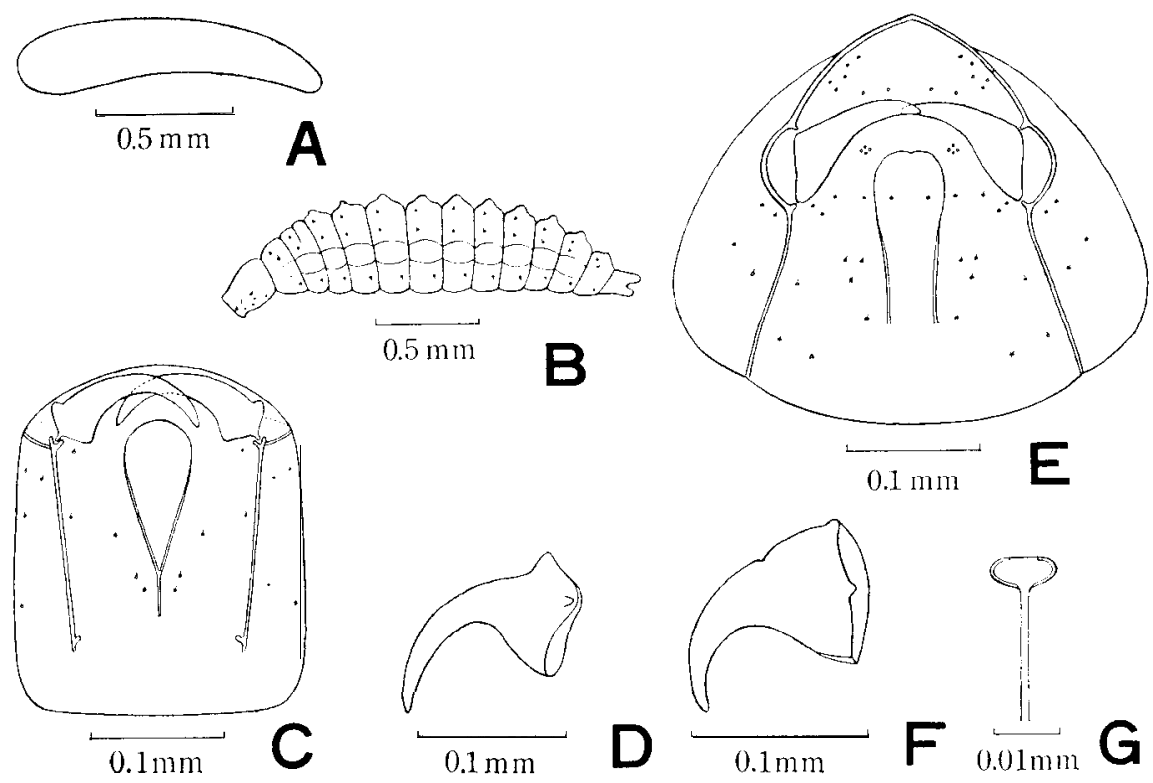

Fig. 5. Itoplectis narangae. A: Egg, B: Lateral view of first instar larva, C: Ventral view of head of first instar larva, D: Mandible of first instar larva, E: Ventral view of head of second instar larva, F: Mandible of second instar larva, G: Spiracle of second instar larva.

Setae present on the body surface as shown in Fig. 5,B. No open spiracles present on the exuviae.

Second instar larva (Fig. 5, E, F and G) ; similar in shape, but larger and more robust than the first instar. Nine pairs of open spiracles present (Fig. 5, G), one pair on prothorax and one on each of the first to eighth abdominal segments. Spiracles of uniform size, diameters of atria of 20 spiracles averaged $0.01 \mathrm{~mm}$. Head (Fig. 5, E) shorter in proportion to its width than that of the first instar. Epistoma complete.

Third instar larva (Fig. 6, A, B and C) : larger and more robust than those of the previous instars. Spiracles (Fig. 6, A) similar to those of second instar except for size; average diameter of atria of 20 spiracles $0.021 \mathrm{~mm}$. Head (Fig. 6, B) wider in proportion to its length than in the previous instars.

Fourth instar larva (Fig. 6, D) : similar to the fifthinstar in general shape except for size. Spiracle similar to those of the third instar in shape except for size. Average diameter of atria of 20 spiracles 0.03 mm. Maxillary and labial paipi readily discriminated.

Fifth instar larva (Fig. 7, A, B, C and D) : widest at the second abdominal 


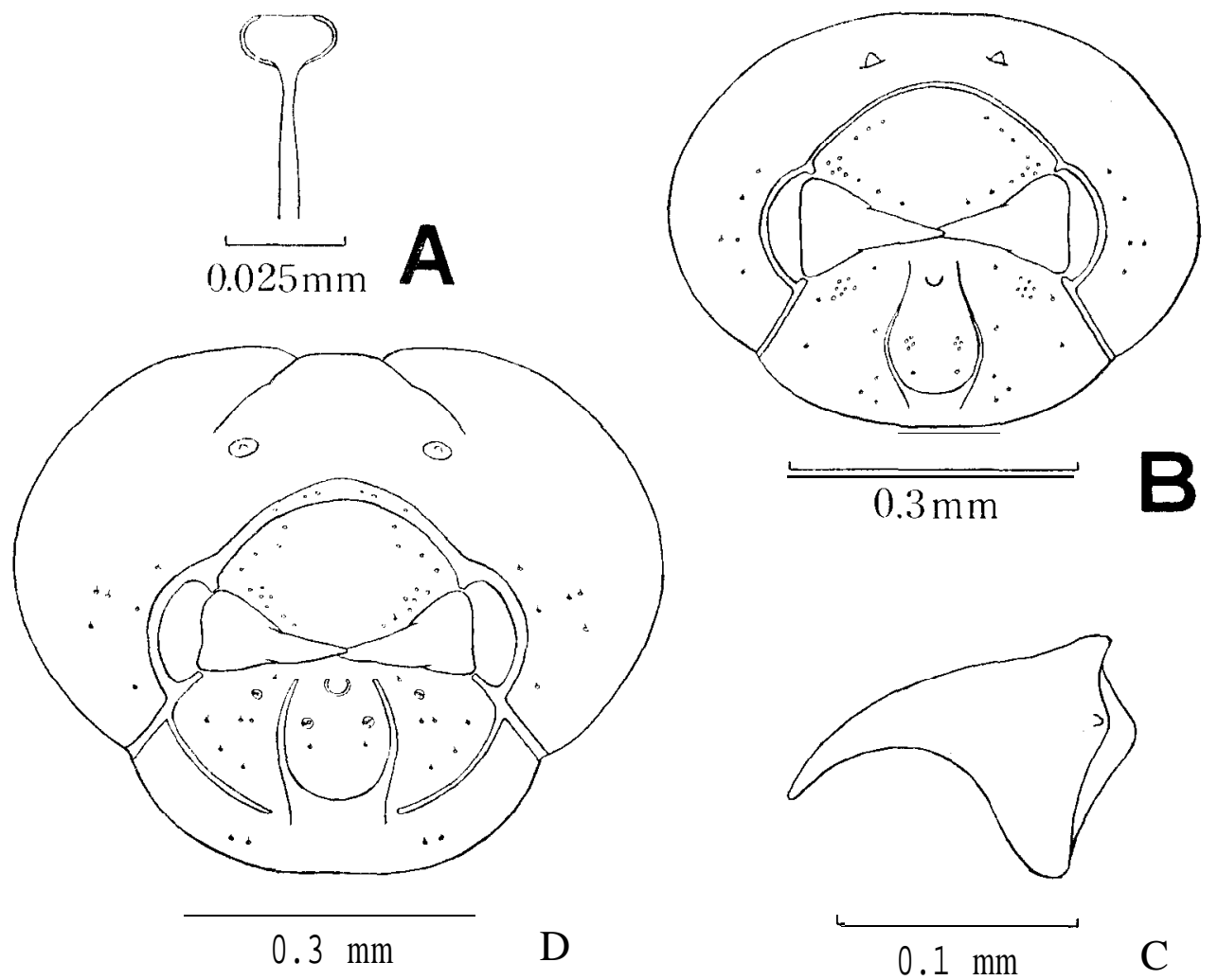

Fig. 6. Itoplectis narangae. A. Spiracle of third instar larva, B: Ventral view of head of third instar larva, C : Mandible of third instar larva, D: Ventral view of fourth instar larva.

segment and tapering towards both ends. Fat balls in the body are seen through the skin as small milky-white points along the sides from dorsum. Distribution of setae on all body segments as illustrated in the figure. Tracheal system well developed and open spiracles on prothorax and first to eighth abdominal segments clearly observed. Shape and size of spiracle remarkably different from those of the previous instar. Atrium of spiracle (Fig. 7, C) oval in shape, about two times as wide as deep, with many protuberances on the walls. Average diameter of atria of 20 spiracles $0.05 \mathrm{~mm}$.

Cephalic structure of this instar (Fig. 7, D) heavily sclerotized. Epistoma complete, joining pleurostoma and hypostomal spurs to form a ring which is broken only by labial sclerite. Each of superior mandibular processes well-formed. Unlike the previous instars, hypostomal arms lacking: indentation present in a region where hypostoma would 

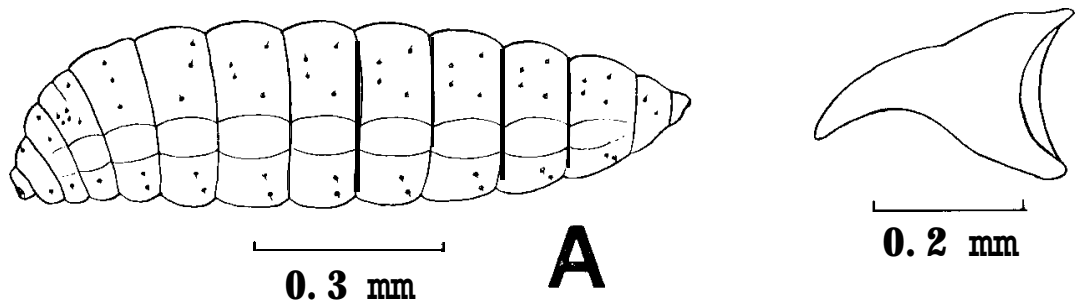

$0.2 \mathrm{~mm}$

B
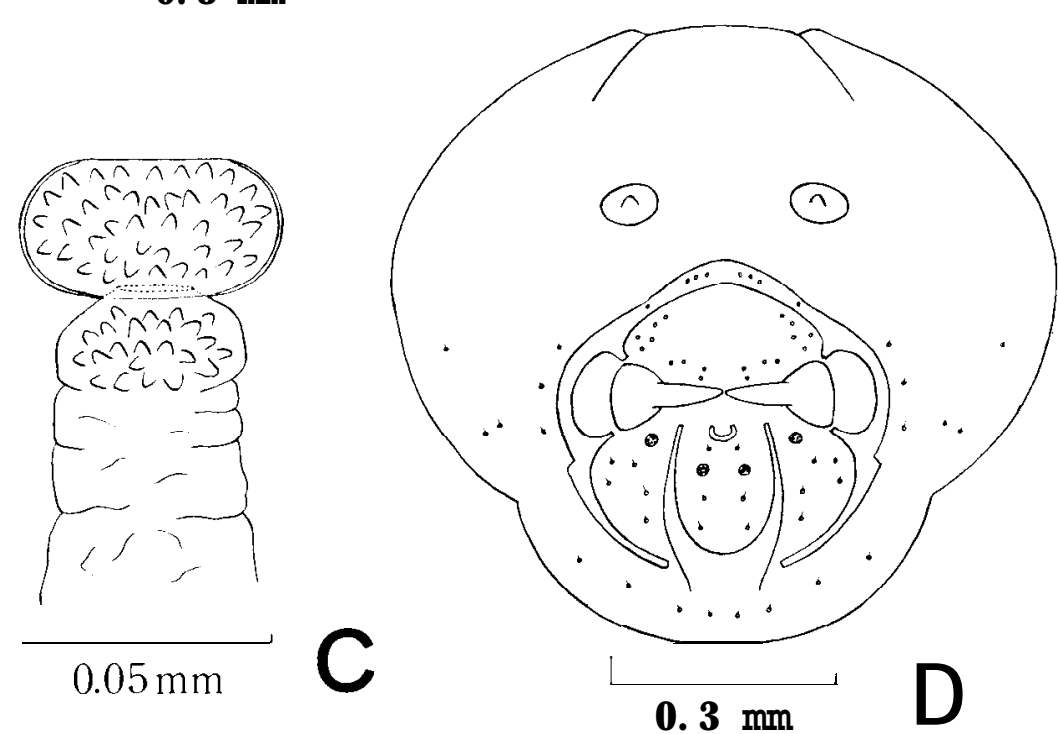

Fig. 7. Itoplectis narangae. A : Lateral view of fifth instar larva, B: Mandible of fifth instar larva, C: Spiracle of fifth instar larva, D): Head of fifth instar larva.

normally arise. Each hypostomal spur heavy-based and long, resting on medial end of small stipital sclerite close to labial sclerite. Basal portion of labial sclerite thickened, with its ventral part slightly rounded; dorsal arms thin, each narrowing dorsally. Silk press lightly sclerotized. Mandible large, without protuberance or teeth. Maxillary and labial palpi each with one large and about six smaller sensoria. Antenna small, disc-like.

Pupa : prepupa yellowish-white and imaginal eyes brown, semicircular, present beneath the skin of pro-mesothorax as time elapses. It changes gradually to the same color of adult at pupal stage. Ovipositor of female pupa starting from the end of the fifth abdominal sternite, running posteriorly and curving along the rear end of the eighth abdominal segment and finally recurving forward covering the dorsum, 


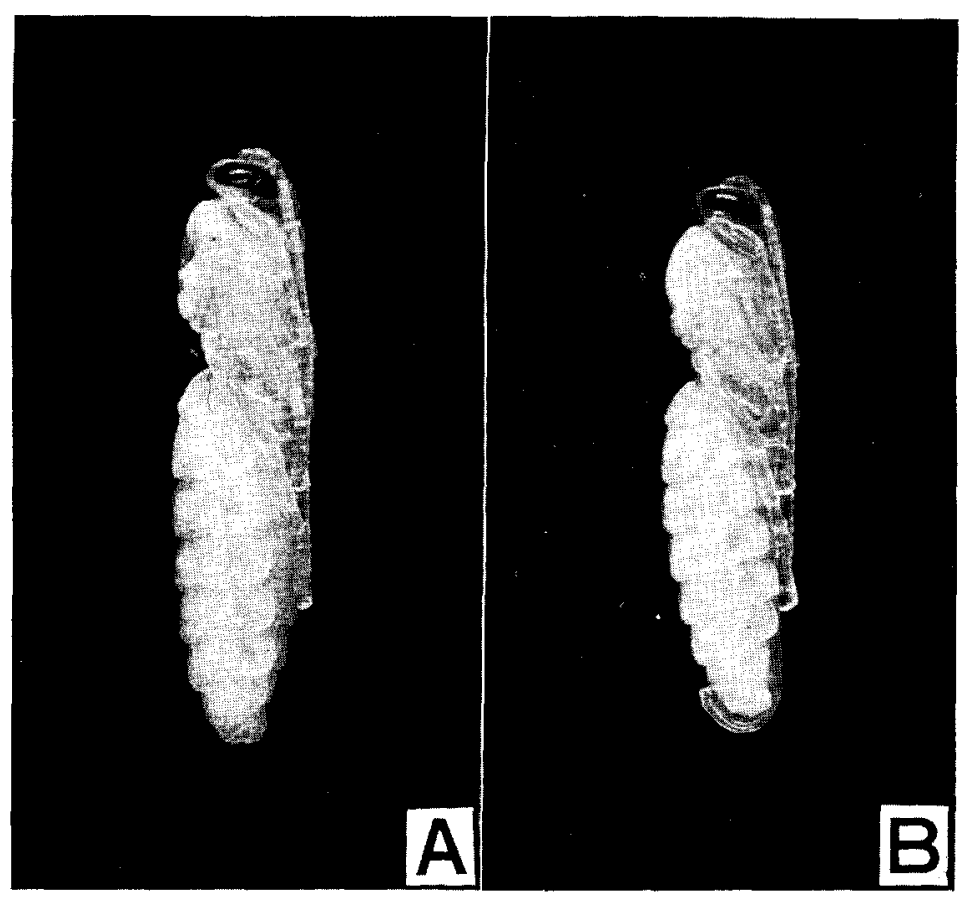

Fig. 8. Itoplectis narangae.

A: Male pupa, B: Female pupa.

thus the tip being beyond the base of seventh abdominal tergite.

\section{2) Developmental period.}

The developmental period of this species within the host in a $25^{\circ} \mathrm{C}$ insectary was investigated, the results of which are illustrated in Fig. 9 .

Egg period was about one day. The larva moved continuously within the egg shell before hatching. Each of the larval period 1, 2, 3 and 4 instars was about one day. When more than 2 eggs were deposited in a single host, there occurred a competition between the parasite larvae and supernumerary parasites were always eliminated. In no instance did more than one parasite complete development in a host. When one larva hatched before the others, the larva destroyed the other eggs with its mandibles. The elimination of supernumerary parasites within the host occurred before the second instar. The super. parasitized pupa of Galleria mellonella dissected on the third day after oviposition showed patches of melanin pigment which were caused by the deposit of melanin on the wounded portions of destroyed parasite 


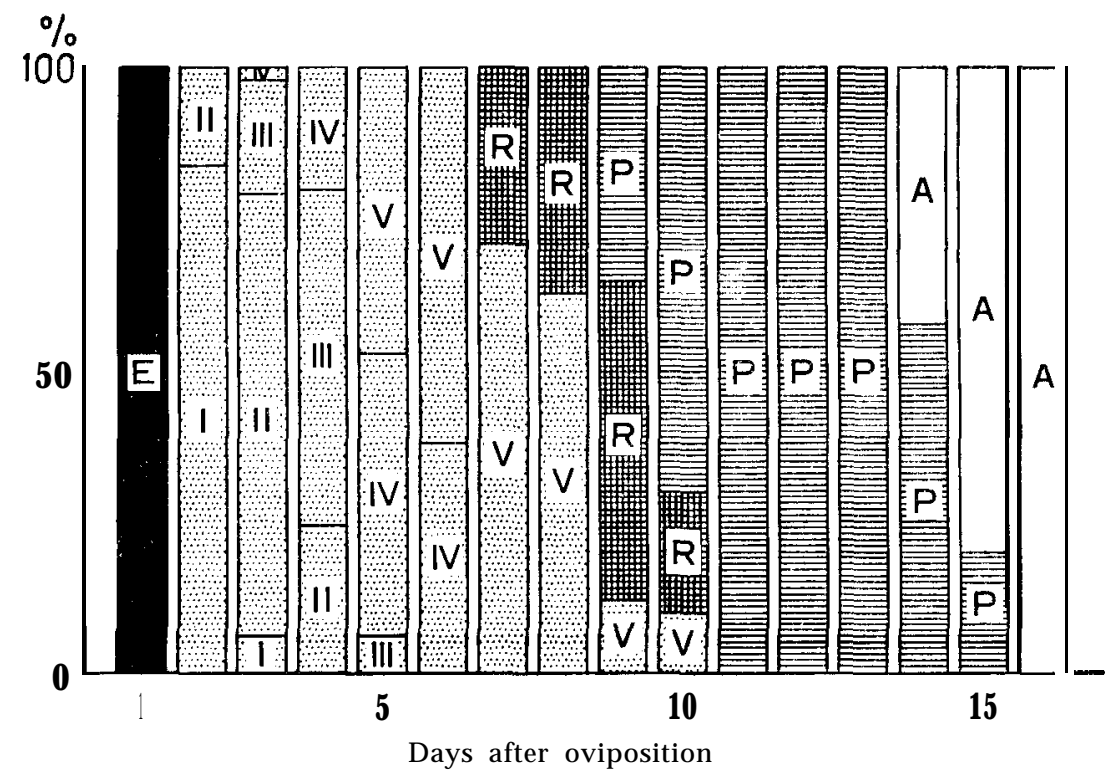

Fig. 9. Developmental stages and period of Ztoplectis narangae reared on G alleria mellonella at $25^{\circ} \mathrm{C}$. I : First instar, II : Second instar, III : Third instar, IV: Fourth instar, V: Fifth instar, A: Adult, E: Egg, P: Pupa, R : Prepupa.

larvae, as observed by Fisher in the case of Nemeritis canescens Gravenhorst and Horogenes chrysostictos Gmelin. The presence of supernumerary larvae did not appear to alter the rate of development or the size of the surviving parasite. The fifth instar was 3 or 4 days. Some of the contents of the host body were observed until the fourth instar, but all of them were completely consumed at the fifth instar larval stage of the parasite. Prepupal period was only one day, while pupal period lasted 5 or 7 days. The adult emerged by gnawing an irregular hole (average diameter $3.5 \mathrm{~mm}$ ) through the host pupal skin usually from the anterior region but sometimes also from the posterior region. When the egg was deposited in the older host, this species sometimes emerged from the abdomen. The average developmental period from egg to adult varied in male and female, the former emerged earlier than the latter. Table 4 shows the developmental period at different temperatures after being oviposited in different host species.

The developmental period varies according to the host species and the individuals reared on the pupae of Chilo suppressalis seemed to spend somewhat longer period than those reared on Galleria mellonella pupae. However, in any case the developmental period was shorter at $30^{\circ} \mathrm{C}$ than at $25^{\circ} \mathrm{C}$. The male always emerged earlier than the female. 
Table 4. Mean developmental period in days of Ztoplectis narangae at different temperatures in different host species.

\begin{tabular}{|c|c|c|c|c|c|}
\hline \multirow[b]{2}{*}{ Host species } & \multirow[b]{2}{*}{$\begin{array}{c}\text { Sex of } \\
\text { parasite }\end{array}$} & \multicolumn{2}{|c|}{$25^{\circ} \mathrm{C}$} & \multicolumn{2}{|c|}{$30^{\circ} \mathrm{C}$} \\
\hline & & $\begin{array}{c}\text { No. of } \\
\text { parasites } \\
\text { observed }\end{array}$ & $\begin{array}{l}\text { Develop- } \\
\text { mental } \\
\text { period }\end{array}$ & $\begin{array}{c}\text { No. of } \\
\text { parasites } \\
\text { observed }\end{array}$ & $\begin{array}{l}\text { Develop- } \\
\text { mental } \\
\text { period }\end{array}$ \\
\hline $\begin{array}{l}\text { *Galleria } \\
\quad \text { mellonella }\end{array}$ & $\begin{array}{l}0 \\
0 \\
0\end{array}$ & $\begin{array}{l}30 \\
30\end{array}$ & $\begin{array}{l}14.0 \\
14.9\end{array}$ & $\begin{array}{l}25 \\
15\end{array}$ & $\begin{array}{l}12.0 \\
14.0\end{array}$ \\
\hline $\begin{array}{l}\text { Chilo } \\
\quad \text { suppressalis }\end{array}$ & $\begin{array}{l}\hat{0} \\
\text { o }\end{array}$ & $\begin{array}{l}20 \\
20\end{array}$ & $\begin{array}{l}15.9 \\
17.3\end{array}$ & $\begin{array}{l}20 \\
20\end{array}$ & $\begin{array}{l}12.5 \\
13.4\end{array}$ \\
\hline $\begin{array}{l}\text { "Leucania } \\
\text { separnta }\end{array}$ & $\begin{array}{l}\hat{O} \\
\stackrel{9}{9}\end{array}$ & $\begin{array}{r}2 \\
12\end{array}$ & $\begin{array}{l}20.0 \\
21.5\end{array}$ & & \\
\hline $\begin{array}{l}\text { Tryporyza } \\
\quad \text { incertulas }\end{array}$ & $\begin{array}{l}3 \\
3 \\
0\end{array}$ & $\begin{array}{l}1 \\
1\end{array}$ & $\begin{array}{l}15.0 \\
16.0\end{array}$ & & \\
\hline $\begin{array}{l}\text { Sesamia } \\
\quad \text { inferens }\end{array}$ & $\begin{array}{c}3 \\
0 \\
0\end{array}$ & $\overrightarrow{1}$ & 20.0 & & \\
\hline $\begin{array}{l}\text { *Parnara } \\
\text { guttata }\end{array}$ & $\begin{array}{l}\hat{0} \\
\text { 우 }\end{array}$ & 2 & 17.5 & & \\
\hline $\begin{array}{l}\text { Cnaphalocrocis } \\
\text { medinalis }\end{array}$ & $\begin{array}{l}00 \\
0\end{array}$ & $\begin{array}{l}2 \\
1\end{array}$ & $\begin{array}{l}14.3 \\
15.0\end{array}$ & & \\
\hline $\begin{array}{l}\text { Naranga } \\
\quad \text { aenescens }\end{array}$ & $\begin{array}{l}-\lambda \\
0 \\
0\end{array}$ & 1 & 14.0 & & \\
\hline
\end{tabular}

The pupae of Galleria mellonella which were parasitized were placed under the room temperature condition (max. $23^{\circ} \mathrm{C}$, min. $8^{\circ} \mathrm{C}$, mean $17.1 “ \mathrm{C}$ ) from October 17 to December 2, 1968. The developmental period was investigated with 18 males and 24 females, the results of which showed 37.7 days for male and 41.8 days for female, indicating more than two times the period reared at $25^{\circ} \mathrm{C}$.

3) Effect of temperatures on the color variation.

Studies on the color variation of parasites emerged at different temperatures have been reported occasionally. Although no morphological difference was reported in the adults of this species reared at different temperatures, a remarkable difference was observed in the development of pigment. According to the work done by Quednau (1960) in the species of Trichogramma, yellow color predominated in the body coloration if reared at higher temperatures and black color specific to each species is well pronounced when reared at low temperature. Similar phenomenon was also observed in this species. Black color was well developed in those reared at low temperature while the reverse was true in those reared at high temperatures.

The color variation of this species reared at different temperatures is summarized in Table 5 . 
Table 5. Color variation of Itoplectis narangae adult reared on Gaileria mellonella at different temperatures.

\begin{tabular}{|c|c|c|c|c|}
\hline \multirow{6}{*}{$\pi$} & & $17^{\circ} \mathrm{C}$ & $25^{\circ} \mathrm{C}$ & $30^{\circ} \mathrm{C}$ \\
\hline & Thorax & Black & Black & Reddish-brown \\
\hline & $\begin{array}{c}\text { Abdominal } \\
\text { segment }\end{array}$ & 7 to 8 black & 7 to 8 dark-red & $\begin{array}{l}7 \text { to } 8 \text { pale } \\
\text { ferruginous }\end{array}$ \\
\hline & Coxae & Brown & Lemon yellow & Lemon yellow \\
\hline & Femur & Proximal $1 / 4$ black & $\begin{array}{l}\text { Proximal } 1 / 5 \\
\text { black }\end{array}$ & $\begin{array}{l}\text { Proximal } 1 / 7 \\
\text { black }\end{array}$ \\
\hline & Tibia & $\begin{array}{l}\text { An annulus at base and } \\
\text { proximal } 1 / 2 \text { black }\end{array}$ & $\begin{array}{l}\text { An annulus at base } \\
\text { and proximal } 1 / 3 \\
\text { black }\end{array}$ & $\begin{array}{l}\text { Without an } \\
\text { annulus, } \\
\text { proximal } 1 / 5 \\
\text { to } 1 / 4 \text { black }\end{array}$ \\
\hline \multirow{5}{*}{3} & Thorax & Black & Black & Reddish-brown \\
\hline & $\begin{array}{c}\text { Abdominal } \\
\text { segment }\end{array}$ & 6 to 8 black & 8 black & $\begin{array}{l}6 \text { to } 8 \text { pale } \\
\text { ferruginous }\end{array}$ \\
\hline & Coxae & Brown & Lemon yellow & Lemon yellow \\
\hline & F e m u r & Proximal $1 / 5$ black & $\begin{array}{l}\text { A black annulus } \\
\text { at apex }\end{array}$ & Without annulus \\
\hline & Tibia & $\begin{array}{l}\text { A black annulus at base } \\
\text { slightly longer than } \\
\text { the black part of femur } \\
\text { proximal } 1 / 3 \text { black }\end{array}$ & $\begin{array}{l}\text { A dark brown } \\
\text { annulus at base, } \\
\text { proximal } 1 / 5 \\
\text { black }\end{array}$ & $\begin{array}{l}\text { Apex dark } \\
\text { brown }\end{array}$ \\
\hline
\end{tabular}

The material collected from the paddy field of Hakozaki, Fukuoka were analyzed by the Table 5 . It is interesting that the color of those collected in the later part of May was similar to that of the individuals reared at $17^{\circ} \mathrm{C}$. The seventh and eighth abdominal segments were black in the females collected in the months of June, October and November. It seemed to correspond nearly the neutral color of those reared at $17^{\circ} \mathrm{C}$ and $25^{\circ} \mathrm{C}$. The females with the black eighth abdominal segment and the light reddish-brown sixth-eighth abdominal segments were mixed among the material collected in the later part of July. This seemed also nearly neutral color of those reared at $25^{\circ} \mathrm{C}$ and $30^{\circ} \mathrm{C}$.

It may be possible to estimate the approximate developmental period of this species by observing these remarkable color variations affected by temepratures.

\section{Habits}

\section{Feeding habit of the adult parasite.}

It has been known by many workers that most of the adults of Hymenopterous parasites feed on honey of flowers, aphid honeydew, host body fluids and other rnaterials which are essential for their 
survival and reproduction.

The adults of some Hymenopterous parasites visit flowering plants of many different families to obtain nectar and pollen (Leius 1960). If there is some flowering plants within the area of activity of the parasites in the field, the flower plays an importants role as the source of food for the reproduction or maintenance of the parasite population (Györfi 1951).

Hirose (1966) reported that this species visits flowers in the carrot field around the paddy field where the author conducted the field study. This indicates that the carrot field plays an important role in the activity of this species.

The host body fluid is an important source of protein diet necessary for oögenesis of the female of synovigenic species (Flanders 1942). Although the host feeding by the females of this species in the field was not observed, the body fluid of pupae of Galleria mellonella, Chilo suppressalis, Leucania separata and Parnara guttata were observed to be fed by this parasite in the laboratory. Similar observations were made by Johnston (1913), Leius (1961) and Arthur (1963) in Ztoplectis conquisitor (Say) and also by Nozato (1969) in Ztoplectis cristatae Momoi.

Experiment (Tables 18 and 19) on the reproductive capacity of this species showed the host feeding almost every day during the oviposition period, but host feeding has never been observed before and after the oviposition period. The adult female of this species deposited her egg by inserting her ovipositor into the host and then fed on the host fluids exuded from the hole immediately after withdrawing her ovipositor. But, the host feeding after egg laying was not done at each oviposition. For example, the adult female fed on the host fluids without depositing any egg, but in case the amount of host fluids was small in quantity, the ovipositor was inserted 2 or 3 times repeatedly into almost the same puncture hole or was pumped and circulated with the inserted ovipositor to enlarge the hole for ready feeding of as much host fluids as possible. In this case, almost all of the host fluids were fed and only the pupal skin remained. Therefore, the role played by this species in the field as a form of predation (DeBach 1943, Flanders 1953) is presumed to be significant.

Townes (1958) pointed out that moisture, particularly in the form of dew, is an important requirement of ichneumonids, and in many cases its scarcity is a limiting factor.

Observation was further made on this species feeding on water on the leaf of rice plant in the field after rains. In the laboratory it also fed on as much water as possible almost every day during the survival period. When this species was liberated immediately after emergence 
in the Container A which was supplied with water and honey, it fed on water and then honey or vice versa whichever it was found first.

Leius (1960) states that aphid honeydew is an important source of food and moisture, especially in early spring and late autumn when flowering plants are scarce. The author observed this species taking honeydew from aphids (species name unknown) on the ear of rice plant in the middle of November when no water was usually available. It is felt, therefore, that this may endorse what Leius states.

\section{Mating habit.}

Males emerge, on an average, slightly ahead of the females and wait for an emerging female. The females were ready to mate immediately after emergence. The mating ratio of older males is higher than that of younger ones, but some males mate soon after emergence. Usually, if not always, the newly emerged males come in contact with the unmated females but do not try to mate. The males become excited when they touch the unmated females with their antennae and then run after and mount them. The male may curl his abdomen around either side of the female, and inserts his genitalia into the females genital chamber which is just above the seventh sternite.

In the laboratory an unmated female was kept together with 4 males in a test tube ( $28 \mathrm{~mm}$ in diameter and $196 \mathrm{~mm}$ in length). One of the males whose antenna came first in contact with the unmated female was successfully mated. The other males mounted on each upon the other and on the mating male. They mated one by one after the accomplishment of mating of the first male, and the male once contacted with the unmated female attempted sexual intercourse with females and even with males near by.

Thus an unmated female successfully mated with 4 males. In this case the time spent for coition was the longest in the first and became shortened gradually from the second to fourth. It may be seen from this observation that the frequency of mating of this species is as a rule only once but the females may be able to mate 2 or 3 times if the newly emerged females encounter a number of males in the field.

They are motionless during mating, but the male's wings and antennae vibrate rhythmically after the lapses of certain times in coitus. The vibration varies in frequency. The time required for coition is shown as in the following Table 6 .

The unmated females can mate with males throughout her life. A pair of male and female which mated immediately after emergence was put in the Container A and observed their behavior by giving Galleria mellonella pupae as host insects. The male did not usually 
Table 6. Time required for coition and frequency of vibration.

\begin{tabular}{|c|c|c|c|c|c|c|}
\hline $\begin{array}{l}\text { Obsv. } \\
\text { no. }\end{array}$ & & $\begin{array}{l}\text { Time } \\
\text { for }\end{array}$ & $\begin{array}{l}\text { required } \\
\text { coition }\end{array}$ & $\begin{array}{r}\text { Time fr } \\
\text { to } \mathrm{V}\end{array}$ & $\begin{array}{l}\text { coition } \\
\text { tion }\end{array}$ & $\begin{array}{c}\text { Frequency of } \\
\text { vibration }\end{array}$ \\
\hline 1 & 2 & $\min$. & $35 \mathrm{sec}$. & 1. $\min$. & $35 \mathrm{sec}$. & 61 \\
\hline 2 & 3 & "I & 45 & "I & 30 & 195 \\
\hline 3 & 5 & "1 & 15 & 2 & 35 & 271 \\
\hline 4 & 6 & 11 & 25 & 5 & 25 & 64 \\
\hline 5 & 14 & " & 55 & 12 & "I & 145 \\
\hline 6 & 1 & נ" & 20 & 1 & 5 & 15 \\
\hline
\end{tabular}

show any response against the female even contacting with her, but tried to mate when the female laid her eggs on the host provided. In this case, if the male tried to mount the female, she promptly brushed him off with her hind legs or resisted against the male by vibrating her wings. However, it was observed occasionally that the male succeeded in coition by vibrating its wings 2 or 3 times. The duration of vibration was relatively shorter than that required for mating of females immediately after emergence.

\section{0 viposition habit.}

\section{1) Searching for host and oviposition.}

According to the observation in the Container A in the laboratory, the oviposition by the gravid female started within 1 minute after the detection of host, if the pupa of Galleria mellonella was provided. They inserted their antennae deeply or thinly through the mesh of gauze, or sometimes inserted the entire antenna of one side with the head leaning to one side to search for the host. Sometimes they were observed to clean their antennae with fore legs. When the host was discovered, they moved around once or twice on the host body vibrating their antennae incessantly to tap the host. If a suitable place was located for oviposition, the female erected her ovipositor vertically to the host body, then moved her body slightly backward and inserted her ovipositor at an angle of $75^{\circ}-80^{\circ}$ to the host body surface after confirming the tip of the ovipositor not slipping off from the host body. The full length of the ovipositor was usually inserted for oviposition, but sometimes withdrew it slightly after the full length insertion as if to adjust the depth. After oviposition they rubbed their ovipositors on the gauze and cleaned the host body fluid thereon. When the pupa of Galleria mellonela was nakedly exposed, some individuals found the host and oviposited within one minute, as in the case of Container A. On the other hand, some did not show any response even when 
they moved frequently on the host body. It took some time for these individuals to find the host and oviposit.

In the field the female of this species was observed moving around on the leaf vibrating its antennae which seemed to tap softly the leaf surface. In the case of the stem, however, she behaved with her antennae holding the stem in the manner described above. When a hole or a crevice was found on the stem, she inserted her one-side antenna fully into the hole or the crevice in order to search for the host.

From these observations it is felt that this species is not only adapted to search for naked host but also adapted to search for the host in hidden places for oviposition. The time required for oviposition is 15 seconds in the shortest case and sometimes more than 14 minutes in the longest case. According to the laboratory observation oviposition occurs more frequently on the thorax rather than on the abdomen of the host pupae. This may be probably attributable to the fact that the host pupa refuses the attack of parasites by moving its abdomen at the time of oviposition.

The relation between the frequency of insertion of the ovipositor and the number of eggs laid was investigated with 10 parasites to each of which one pupa of Galleria mellonella was provided. The host was taken out and dissected after one insertion of the ovipositor to count the number of eggs deposited. Similar experiment was conducted on the host in which the ovipositor was inserted twice. As shown in Table 7, it was clearly proved that only one egg was deposited by one insertion of the ovipositor.

Table 7. Relation between the frequency of insertion of the ovipositor of Itoplectis narangae into the pupa of Galleria mellonella and the number of eggs deposited.

\begin{tabular}{|c|c|c|c|c|c|c|c|c|c|c|c|c|}
\hline \multirow{2}{*}{$\begin{array}{l}\text { Frequency of } \\
\text { insertion of } \\
\text { ovipositor }\end{array}$} & \multicolumn{12}{|c|}{ Parasite number } \\
\hline & 1 & 2 & & 3 & 4 & & 5 & 6 & 7 & 8 & 9 & 10 \\
\hline 1 & 1 & 1 & & 0 & & 0 & 1 & $\mathbf{1}$ & $\mathbf{0}$ & 1 & $\mathbf{1}$ & 1 \\
\hline 2 & 12 & & 2 & & 2 & & 2 & 2 & & 1.2 & 0 & 1 \\
\hline
\end{tabular}

2) Relation between the age in days of the host pupa and the number of eggs deposited.

Experiments were conducted to see the effect of the age in days of the host pupa on the oviposition of this species.

Methods : In the first experiment which was performed by using the 
Container B, 3 pupae of $\mathbf{G}$ alleria mellonella uniform in size and younger than 24 hours old were exposed to a single parasite. This experiment lasted for 8 days using 6 adult females each of which was provided daily with 3 pupae of different ages ranging from 1 day to 8 days successively.

Container B was also used for the second experiment and the pupae

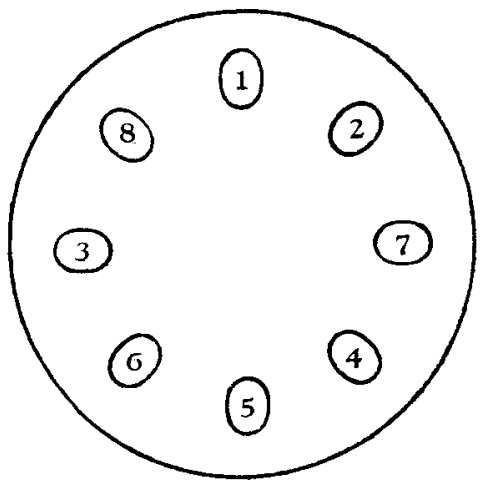

Fig. 10. Arrangement of hosts. of Galleria mallonella of each different age in days were arranged and pasted on a cardboard as illustrated in Fig. 10 (the figure in circle represents the age in days of each host).

They were exposed simultaneously to each of 10 adult females for 24 hours. The dissection of the hosts was made under a binocular microscope to count the number of eggs deposited.

Results : The results of these experiments are presented in the following Tables 8 and 9 .

From Tables 8 and 9 , it seems that the oviposition takes place evenly throughout the age-range 1 to 8 days. Therefore, the difference of the age in days seems to have no effect upon the parasite oviposition. The difference in the number of eggs deposited by the age in days does not indicate a declining tendency, and particularly no difference by the age in days may be noticed.

Table 8. Age in days of the pupae of Galleria mellonella and number of eggs deposited by Itoplectis narangae.

\begin{tabular}{|c|c|c|c|c|c|c|c|}
\hline \multirow{2}{*}{$\begin{array}{l}\text { Age in } \\
\text { days }\end{array}$} & \multicolumn{6}{|c|}{ Parasite number } & \multirow{2}{*}{ Total } \\
\hline & 1 & 2 & 3 & 4 & 5 & 6 & \\
\hline 1 & 25 & 18 & 16 & 11 & 9 & 18 & 97 \\
\hline 2 & 27 & 17 & 11 & 1 & 27 & 10 & 93 \\
\hline 3 & 23 & 13 & 14 & 4 & 16 & 9 & 79 \\
\hline 4 & 12 & 12 & 15 & 2 & 12 & 13 & 66 \\
\hline 5 & 10 & 14 & 10 & 4 & 20 & 11 & 69 \\
\hline 6 & 14 & 19 & 21 & 11 & 28 & 9 & 102 \\
\hline 7 & 16 & 14 & 13 & 6 & 21 & 11 & 81 \\
\hline 8 & 19 & 10 & 11 & 5 & 15 & 9 & 69 \\
\hline
\end{tabular}


Table 9. Number of eggs deposited by Itoplectis narangae when the pupae of Galleria mellonella of different ages were given simultaneously.

\begin{tabular}{|c|c|c|c|c|c|c|c|c|c|c|c|}
\hline \multirow{2}{*}{$\begin{array}{l}\text { Age in } \\
\text { days }\end{array}$} & \multicolumn{9}{|c|}{ Parasite number } & \multicolumn{2}{|c|}{ Tot a I } \\
\hline & 1 & 2 & 3 & 4 & 5 & 6 & 7 & 8 & 9 & 10 & 80 \\
\hline 1 & 0 & 7 & 4 & 6 & & & 3 & 2 & 12 & 3 & 31 \\
\hline 2 & 9 & 7 & 17 & 6 & 3 & 3 & 7 & 4 & 7 & 5 & 68 \\
\hline 3 & 3 & 3 & 7 & 2 & 3 & 3 & 3 & 5 & 3 & 7 & 39 \\
\hline 4 & 10 & 1 & 2 & 1 & 1 & 3 & 5 & 2 & 7 & 3 & 35 \\
\hline 5 & 7 & 4 & & & 13 & 6 & & 5 & 4 & 13 & 36 \\
\hline 6 & 4 & 0 & & 3 & 7 & 18 & & 4 & 2 & 4 & 34 \\
\hline 7 & 3 & & 1110 & & 2 & & 3 & 3 & & 11 & 16 \\
\hline 8 & 3 & 5 & 3 & 1 & 6 & 6 & 3 & 4 & 2 & 0 & 33 \\
\hline Total & 39 & 28 & 37 & 21 & 26 & 27 & 36 & 27 & 25 & 26 & \\
\hline
\end{tabular}

\section{3) Relation between the dorsal and ventral sides of the host pupa and the number of eggs deposited.}

The ventral and dorsal sides of the pupa of Galleria mellonella differ slightly, the former being smooth with thin pupal skin, while the latter having many small processes with thick pupal skin.

Experiment was further conducted by using the Container A to see whether such differences have any influences on the oviposition of the parasite.

Method : Three host pupae (one-day, three-days and five-days old) were pasted with their ventral or dorsal side kept upward on a cardboard and exposed to five parasites for 24 hours at 2 days interval. The dissection of the hosts was made under a binocular microscope to count the number of eggs deposited.

Result: The results are presented in Table 10.

No remarkable difference was observed between the oviposition on

Table 10. Number of eggs deposited to the dorsal and ventral sides of the pupae of Calleria mellonella by Itoplectis narangae.

\begin{tabular}{|c|c|c|c|c|c|c|c|c|c|c|c|c|}
\hline \multirow{2}{*}{$\begin{array}{l}\text { Age in } \\
\text { days }\end{array}$} & \multicolumn{5}{|c|}{ Dorsal side } & \multirow{2}{*}{ Total } & \multicolumn{5}{|c|}{ Ventral side } & \multirow{2}{*}{ Total } \\
\hline & 1 & 2 & 3 & 4 & 5 & & 1 & 2 & 3 & 4 & 5 & \\
\hline 1 & 43 & 28 & 40 & 21 & 29 & 161 & 27 & 22 & 28 & 30 & 30 & 127 \\
\hline 3 & 33 & 12 & 40 & 16 & 10 & 111 & 11 & 17 & 23 & 25 & 18 & 94 \\
\hline 5 & 37 & 26 & 31 & 9 & 12 & 115 & 22 & 17 & 16 & 35 & 16 & 106 \\
\hline
\end{tabular}


the dorsal and ventral sides. The number of eggs deposited on the dorsal side was slightly superior to that on the ventral side. This indicates that the small processes and thickness of the pupal skin have no relation to the oviposition behavior.

4) Relation between the size of the host pupae and the number of eggs deposited.

A considerable difference was observed in the size of the pupae of Galleria mellonella according to their nutritional condition during the larval stages. Investigation was carried out to see whether the size of the host pupae affects the parasite oviposition.

Method: The host pupae were grouped into 2 plots according to their size, large and small and pasted on a cardboard by using the Container $A$ and then 5 parasites were provided to each plot. The hosts were renewed every day for 3 days. The dissection of the hosts was made under a binocular microscope to count the number of eggs deposited.

It may be seen from Table 11 that the size of the host pupae give no effect in particular upon the parasite oviposition.

Table 11. Number of eggs deposited by Itoplectis narangae to Galleria mellonella pupae of different sizes.

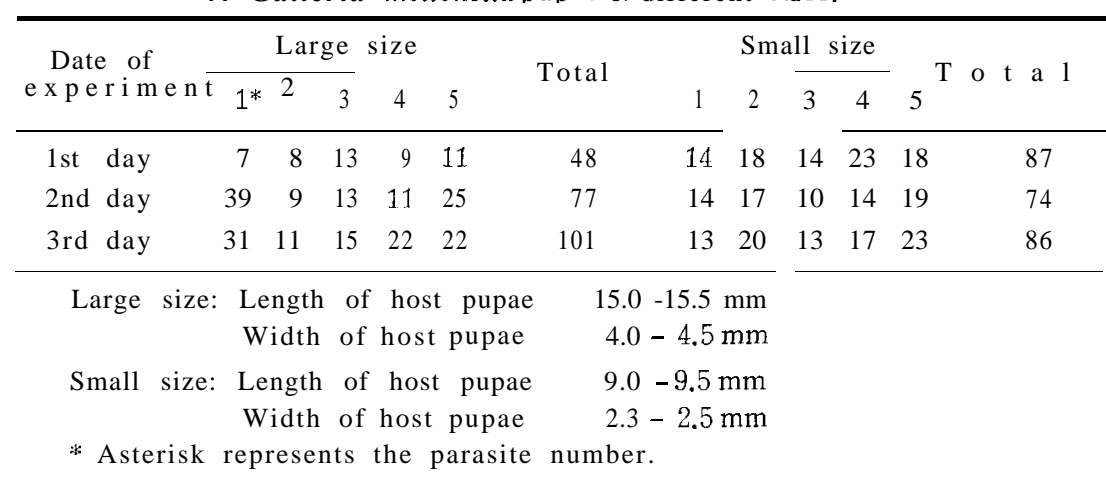

\section{5) Superparasitism.}

Even if this species superparasitized a single host pupa, only one parasite developed without any exceptions. Therefore, it seems important to prevent superparasitism to a minimum extent so as to increase the percentage of parasitism and to prevent the loss of efficiency per female due to the wasting of eggs for the mass production of this species.

The following experiments were conducted for this purpose.

Methods: Experiment was carried out in the Container B and the 
pupae of Galleria mellonella of nearly uniform in size were used as hosts. The parasites were provided with undiluted honey and water for diets. A proper number of the hosts necessary for the experiment was pasted at regular intervals on cardboards as illustrated below.

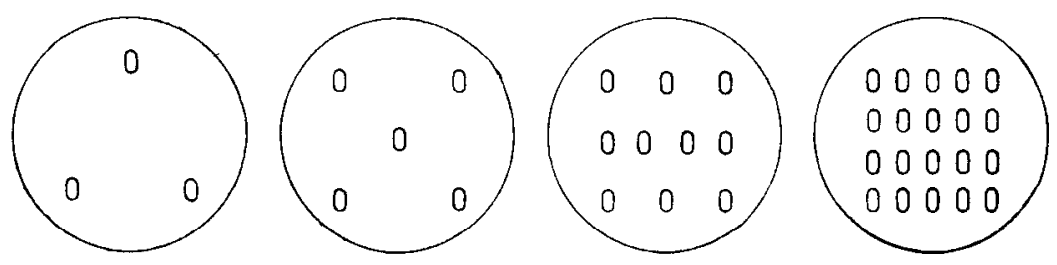

Fig. 11. Arrangement of hosts.

The dissection of the hosts was made under a binocular microscope to count the number of eggs deposited.

In the first experiment one parasite was provided with $3,5,10$ and 20 hosts respectively for 3 hours. This procedure was repeated 10 times. In the second experiment, one parasite was exposed to 10 and 20 hosts respectively for one and three hours and repeated 10 times. In the third experiment, the following combinations of hosts and parasites were tried, i. e., one parasite with 10 or 20 hosts and three parasites with 10 or 20 hosts, and each experiment was repeated 10 times.

Results: The results of these experiments are presented in Tables 12,13 and 14.

Table 12. Results of exposing 3, 5, 10 and 2\$ळ 6 Galleria mellonella to 1 female Itoplectis narangae for 3 hours (10 replicates).

\begin{tabular}{|c|c|c|c|c|c|c|c|c|c|c|c|}
\hline \multirow{2}{*}{$\begin{array}{l}\text { No. of } \\
\text { hosts } \\
\text { exposed }\end{array}$} & \multicolumn{11}{|c|}{ No. of eggs deposited in host pupae } \\
\hline & 0 & 2 & 4 & 6 & 8 & 10 & 11 & 12 & 13 & 15 & 16 \\
\hline 3 & 1 & 1 & 2 & 6 & 1 & 2 & 1 & 1 & - & 1 & 1 \\
\hline 5 & 6 & 715 & 7 & 4 & 3 & 6 & - & & -- & --- & - \\
\hline 10 & 16 & 27 & 20 & 14 & 12 & 6 & 2 & 3 & ---- & --- & - \\
\hline 20 & 90 & 63 & 31 & & 12 & 3 & 1 & - & $-\quad-\quad--$ & $---\quad \quad-$ & - \\
\hline $\begin{array}{l}\text { No. of } \\
\text { hosts } \\
\text { exposed }\end{array}$ & $\begin{array}{c}\text { Total } \\
\text { no. of } \\
\text { hosts }\end{array}$ & & $\begin{array}{c}\text { Total } \\
\text { no. of } \\
\text { parasite } \\
\text { eggs }\end{array}$ & & $\begin{array}{l}\text { \% of } \\
\text { hosts } \\
\text { super- } \\
\text { para- } \\
\text { sitized }\end{array}$ & & $\begin{array}{c}\% \\
\text { para- } \\
\text { sitism }\end{array}$ & & $\begin{array}{l}\text { Average } \\
\text { no. of } \\
\text { eggs per } \\
\text { host }\end{array}$ & $\begin{array}{c}\text { Average } \\
\text { no. of } \\
\text { eggs } \\
\text { laid per } \\
\text { female }\end{array}$ & \\
\hline 3 & $30^{\prime}$ & & 186 & & 93 & & 97 & & 6.2 & 18.6 & \\
\hline 5 & 50 & & 142 & & 74 & & 88 & & 2.8 & 14.2 & \\
\hline 10 & 100 & & 220 & & 57 & & 84 & & 2.2 & 22.0 & \\
\hline 20 & 200 & & 178 & & 24 & & 55 & & 0.9 & 17.8 & \\
\hline
\end{tabular}


Table 13. Results of exposing 10 and 20 pupae of Galleria mellonella to 1 female of Itoplectis narangae for 1 hour and 3 hours (10 replicates).

\begin{tabular}{|c|c|c|c|c|c|c|c|c|c|c|}
\hline \multirow{2}{*}{$\begin{array}{c}\text { No. of } \\
\text { hosts } \\
\text { exposed }\end{array}$} & \multirow{2}{*}{\multicolumn{2}{|c|}{$\begin{array}{c}\text { Period } \\
\text { of } \\
\text { exposure }\end{array}$}} & \multicolumn{8}{|c|}{ No. of eggs deposited in host pupae } \\
\hline & & & 0 & 1 & 2 & 3 & 4 & 5 & 6 & 7 \\
\hline \multirow{2}{*}{10} & \multirow{2}{*}{\multicolumn{2}{|c|}{$\begin{array}{l}1 \text { hour } \\
3 \text { hrs. }\end{array}$}} & 27 & 31 & 25 & 10 & 4 & 2 & - & 1 \\
\hline & & & 16 & 27 & 20 & 14 & 12 & 6 & 2 & 3 \\
\hline \multirow{2}{*}{20} & \multirow{2}{*}{\multicolumn{2}{|c|}{$\begin{array}{l}1 \text { hour } \\
3 \text { hrs. }\end{array}$}} & 108 & 57 & 24 & 9 & 2 & - & - & - \\
\hline & & & 90 & 63 & 31 & 12 & 3 & 1 & - & - \\
\hline $\begin{array}{l}\text { No. of } \\
\text { hosts } \\
\text { exposed }\end{array}$ & $\begin{array}{c}\text { Period } \\
\text { of } \\
\text { exposure }\end{array}$ & $\begin{array}{c}\text { Total } \\
\text { no. of } \\
\text { parasite } \\
\text { eggs }\end{array}$ & & $\begin{array}{c}\mathscr{8} \\
\text { para- } \\
\text { sitism }\end{array}$ & & $\begin{array}{l}\text { \% of } \\
\text { hosts } \\
\text { super- } \\
\text { para- } \\
\text { sitized }\end{array}$ & $\begin{array}{l}\text { No. ot } \\
\text { eggs pe } \\
\text { host }\end{array}$ & & $\begin{array}{l}\text { No. of } \\
\text { eggs } \\
\text { laid per } \\
\text { female }\end{array}$ & \\
\hline 10 & 1 hour & 144 & & 73 & & 42 & 1.4 & & 14.4 & \\
\hline 10 & 3 hrs. & 220 & & 84 & & 57 & 2.2 & & 22.2 & \\
\hline 0 & 1 hour & 140 & & 46 & & 18 & 0.7 & & 14.0 & \\
\hline 20 & 3 hrs. & 178 & & 55 & & 24 & 0.9 & & 17.8 & \\
\hline
\end{tabular}

Table 14. Results of exposing 10 and 20 pupae of Galleria mellonella to 1 female and 3 females of Itoplectis narangae respectively for 3 hours (10 replicates).

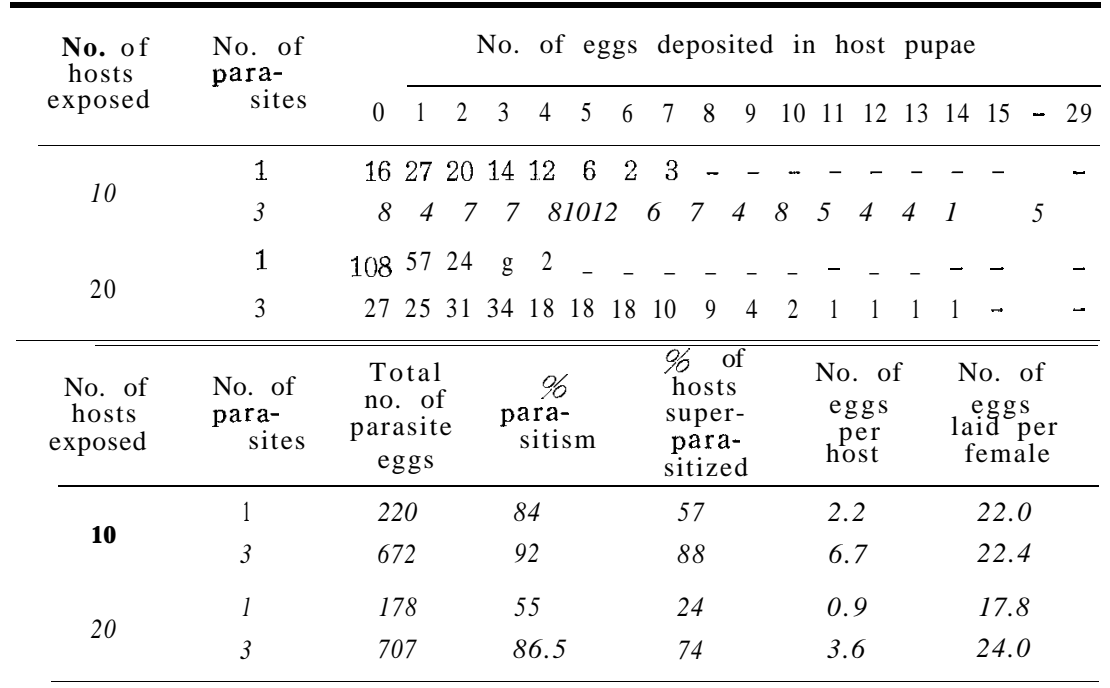


The average number of eggs deposited per host increases when a small number of the hosts is exposed, while the average number of eggs deposited per host decreases as the number of the hosts becomes increased. However, no difference was observed in the average number of eggs deposited per female. This may indicate that the parasites do not tend to concentrate their oviposition on the hosts and that the oviposition has no relation to the number of hosts.

Observation on the actual oviposition showed that the parasite left the site after oviposition and moved around in search for other hosts. The largest number of eggs laid by one host was 16 . The oviposition of more than 2 eggs occupied $93 \%$ of the case in which 3 hosts were provided and $24 \%$ in case of 20 hosts. The number of hosts which were not oviposited was figured out to be 90 out of 200 hosts provided. Therefore, it is felt that this species seems to be unable to discriminate the parasitized or unparasitized hosts.

As shown in Table 13, the average number of eggs deposited per female increased when the hosts were exposed for 3 hours as compared with that of 1 hour. Usually this species leaves the host after ovipositing 5 to 6 eggs, rests for a while and feeds honey and again starts for oviposition. Of course, this observation was made in the laboratory. In the field the hosts are not so abundant as in the laboratory condition. Therefore, it seems that the host feeding is essential to maintain the energy for the next searching and ovipositing behavior of the parasite.

If we take the total number of eggs deposited during 3 hours as a standard $(100 \%)$, the total number of eggs depostited for the first 1 hour corresponds $6579 \%$ as shown in Table 13. It may be seen from this that the percentage in the number of eggs will be decreased as the lapse of time. In another word, an increase in the number of eggs deposited will eventually enhance the percentage of parasitism and superparasitism.

As seen in Table 14, it may be said that the more the parasites the higher the percentage of parasitism or superparasitism. But this does not mean that some remarkable variations may be observed in the average number of eggs deposited per female.

Observation was also made on the oviposition by exposing 10 parasites to 20 hosts. Almost all of them oviposited simultaneously and 2 or 3 parasites also laid eggs at the same time on a single host.

These experiments may offer fundamental clues to develop a proper method of mass production of this species to enhance the percentage of parasitism and reduce the superparasitism. "This procedure may include the shortening of the exposure time of the host pupae so as to prevent the chance of superparasitism. 


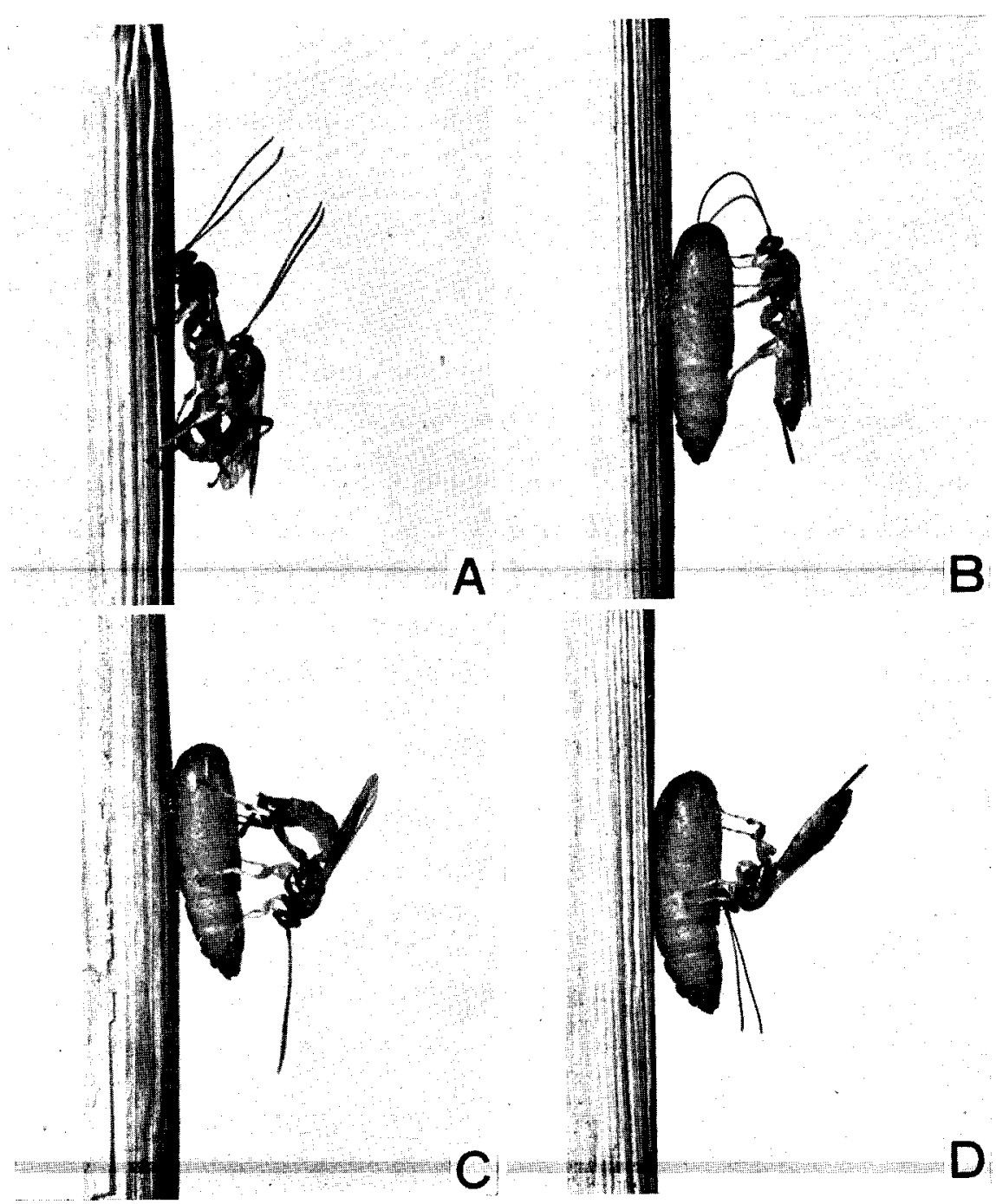

Fig. 12. Habits of Itoplectis narangae. A: Copulation, B: Searching for host, C: Oviposition, D: Host feeding.

\section{Reproductive capacity}

The reproductive capacity of parasites is one of the most important factors in estimating and evaluating the effectiveness of natural enemies.

In order to see the reproductive capacity of this species, the develop- 
mental process of matured eggs in the ovary of adult females was investigated together with the number of eggs deposited by the parasites into the host pupae of Galleria mellonella in a $25^{\circ} \mathrm{C}$ insectary.

\section{Number of matured eggs in the ovary.}

Methods: Adult females soon after emergence were put in the Container $\mathrm{B}$, reared in a $25^{\circ} \mathrm{C}$ insectary and separated into two groups, the first fed with of those which were undiluted honey and water and the second unfed. Ten females of each group were dissected every day for 10 and 4 days for the former and latter groups, respectively, and then the number of matured eggs in the ovaries were counted under a binocular microscope.

Results: The results of this experiments are presented in Tables 15 and 16 and Fig. 13 which illustrates the mean value with $95 \%$ confidence limit.

Table 15. Number of matured eggs in the ovary of unfed Itoplectis narangae.

\begin{tabular}{ccccccccccccc}
\hline \multirow{2}{*}{$\begin{array}{c}\text { Days after } \\
\text { emergence }\end{array}$} & \multicolumn{1}{c}{$\begin{array}{c}\text { Number of matured eggs in the } \\
\text { ovary of } 10\end{array}$ females } \\
\hline $\mathbf{0}$ & 0 & 0 & 0 & 0 & 0 & 0 & 0 & 0 & 0 & 0 & Average \\
1 & 2 & 6 & 0 & 1 & 0 & 2 & 0 & 0 & 1 & 5 & $1.7 \pm 1.9$ \\
2 & 3 & 0 & 8 & 7 & 2 & 3 & 4 & 11 & 1 & 0 & $3.9 \pm 2.7$ \\
3 & 0 & 0 & 0 & 3 & 1 & 6 & 5 & 0 & 0 & 0 & $1.5 \pm 1.9$ \\
4 & 1 & 0 & 0 & 0 & 0 & 3 & 0 & 0 & 0 & 0 & $0.4 \pm 0.6$ \\
\hline
\end{tabular}

Table 16. Number of matured eggs in the ovary of Itoplectis narangae fed with undiluted honey and water.

\begin{tabular}{crrrrrrrrrrrr}
\hline \multirow{2}{*}{$\begin{array}{c}\text { Days after } \\
\text { emergence }\end{array}$} & \multicolumn{8}{c}{$\begin{array}{c}\text { Number of matured eggs in the } \\
\text { ovary }\end{array}$ of 10} \\
\hline & 0 & 0 & 0 & 0 & 0 & 0 & 0 & 0 & 0 & 0 & Average \\
\hline 1 & 0 & 0 & 2 & 3 & 3 & 0 & 2 & 0 & 0 & 0 & $1 \pm 0.9$ \\
2 & 7 & 5 & 14 & 1 & 13 & 6 & 5 & 8 & 5 & 0 & $6.4 \pm 1.1$ \\
3 & 8 & 11 & 17 & 6 & 10 & 13 & 7 & 9 & 5 & 17 & $10.3 \pm 3.1$ \\
4 & 14 & 7 & 14 & 8 & 11 & 8 & 8 & 2 & 8 & 5 & $8.5 \pm 2.6$ \\
5 & 6 & 8 & 11 & 18 & 9 & 3 & 8 & 11 & 3 & 10 & $8.7 \pm 3.0$ \\
6 & 10 & 12 & 10 & 8 & 8 & 10 & 7 & 2 & 12 & 10 & $8.9 \pm 2.1$ \\
7 & 4 & 6 & 6 & 18 & 7 & 5 & 8 & 6 & 10 & 9 & $7.9 \pm 3.0$ \\
8 & 11 & 7 & 5 & 10 & 4 & 4 & 3 & 15 & 10 & 5 & $7.4 \pm 2.8$ \\
9 & 11 & 7 & 4 & 9 & 5 & 8 & 2 & 3 & 7 & 11 & $6.7 \pm 2.3$ \\
10 & 5 & 11 & 3 & 7 & 5 & 5 & 5 & 10 & 3 & 6 & $6.0 \pm 1.8$ \\
\hline
\end{tabular}




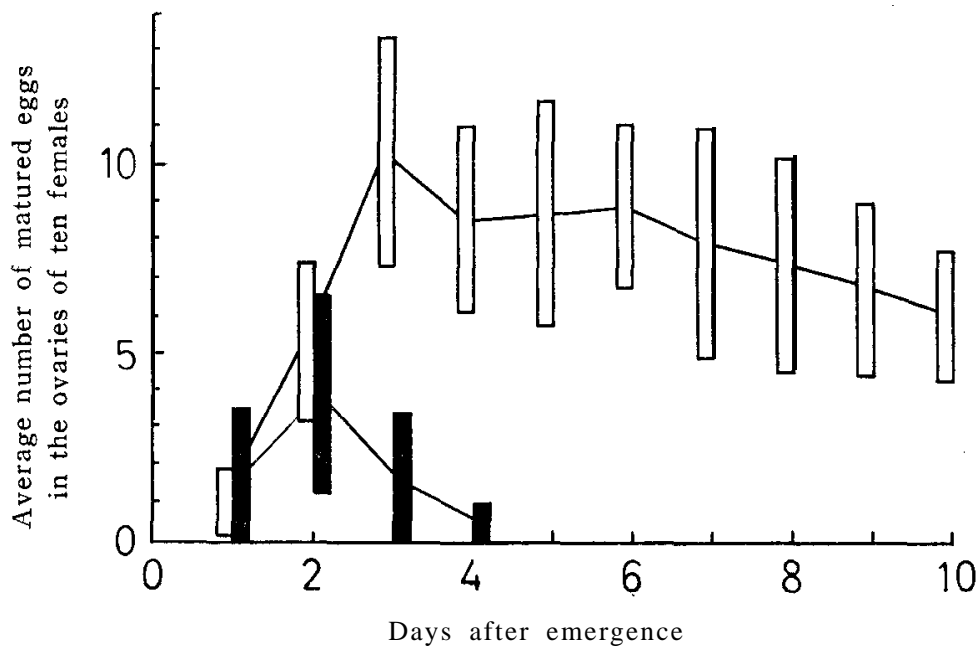

Fig. 13. Average number of mature eggs in the ovaries of Itoplectis narangae unfed (black) and fed with honey and water (white).

As shown in Table 16, soon after emergence no matured eggs were observed in the female fed with undiluted honey and water. The number of matured eggs were increased rapidly from the first day after emergence and reached the maximum on the third day and remained constant during the following three days and began to decrease by the o\&sorption which took place gradually from the seventh day.

There is practically no difference in the number of matured eggs between the females fed and unfed until the first day after emergence as shown clearly in Tables 15 and 16. However, the number reached the maximum on the second day, and thereafter the oösorption took place rapidly, and dead individuals were seen after the fourth day. It seems that the number of matured eggs produced on the second day by unfed females was probably the limit number that might be produced by the nutrients preserved at the time of emergence. This may indicate that the females are seemed to be able to deposit a few eggs even if she can find no diet for about one day after emergence. The number of matured eggs laid by the female fed with undiluted honey reached the maximum one day later than that found in the case of unfed females. Edwards (1954) stated that this difference is presumed attributable to small amount of protein in the honey that was used for egg production.

Table 17 shows the comparison of the number of ovarioles of 3-day old females of this species reared on undiluted honey and water after 
emergence in relation to the number of matured eggs.

It may be seen from Table 17 that the number of matured eggs is about $50 \%$ of the number of ovarioles and that there are no cases 2 matured eggs in a single ovariole (matured egg is always located on the distal portion of the ovarioles). Therefore, it seems that at the time of emergence the number of matured eggs produced by the use of its own nutrients and further supplied with honey does not increase in number as to the same level as those of the ovarioles.

Table 17. Number of ovarioles of S-day old female fed on undiluted honey and water in relation to the number of matured eggs.

\begin{tabular}{|c|c|c|c|c|}
\hline \multirow{2}{*}{$\begin{array}{l}\mathrm{P} \text { ar a s it e } \\
\text { number }\end{array}$} & \multicolumn{3}{|c|}{ Number of ovarioles } & \multirow{2}{*}{$\begin{array}{c}\text { No. of } \\
\text { matured } \\
\text { eggs in the } \\
\text { ovarv }\end{array}$} \\
\hline & Left & Right & Total & \\
\hline 1 & 8 & 9 & 17 & 8 \\
\hline 2 & 12 & 13 & 25 & 11 \\
\hline 3 & 10 & 10 & 20 & 17 \\
\hline 4 & 9 & 7 & 16 & 6 \\
\hline 5 & 10 & 9 & 19 & 10 \\
\hline 6 & 11 & 11 & 22 & 13 \\
\hline 7 & 7 & 8 & 15 & 7 \\
\hline 8 & 8 & 8 & 16 & 9 \\
\hline 9 & 9 & 9 & 18 & 5 \\
\hline 10 & 9 & 10 & 19 & 17 \\
\hline Total & 93 & 94 & 187 & 103 \\
\hline
\end{tabular}

\section{Number of eggs deposited.}

Methods: Investigation was conducted on 10 mated and 10 unmated adult females of different size. The newly emerged parasite was put in the Container A, and then 3 host pupae of Galleria mellonella not older than 3 days after pupation were given every day until the parasite died. The host pupae were taken out daily and dissected to count the number of eggs deposited. Length of forewing of the dead adult females was measured and then dissected. The number of matured eggs remained in the ovary was also counted. During the course of experiment, undiluted honey was provided once every 3 days, water once every day and the container was renewed once every week.

Results: The results of this experiment- are presented in Tables 18 and 19 .

The adult females after emergence became inactive, very sluggish 
Table 18. Number of eggs deposited by ten mated females of Itoplectis narangae.

\begin{tabular}{|c|c|c|c|c|c|c|c|c|c|c|}
\hline \multirow{2}{*}{$\begin{array}{c}\text { Days } \\
\text { after } \\
\text { emergence }\end{array}$} & \multicolumn{10}{|c|}{ Parasite number } \\
\hline & 1 & 2 & 3 & 4 & 5 & 6 & 7 & 8 & 9 & 10 \\
\hline $\begin{array}{l}3 \\
4 \\
5\end{array}$ & $\begin{array}{l}3 \\
3\end{array}$ & 13 & $\begin{array}{l}2 \\
4 \\
6\end{array}$ & $\begin{array}{r}5 \\
11 \\
11 \\
12\end{array}$ & 7 & 3 & $\begin{array}{r}6 \\
3 \\
14\end{array}$ & 2 & $\begin{array}{r}6 \\
6 \\
25\end{array}$ & 4 \\
\hline $\begin{array}{r}6 \\
7 \\
8 \\
9 \\
10\end{array}$ & $\begin{array}{r}7 \\
4 \\
7 \\
20 \\
21\end{array}$ & $\begin{array}{l}13 \\
18 \\
13 \\
15 \\
33\end{array}$ & $\begin{array}{l}13 \\
15 \\
13 \\
10 \\
19\end{array}$ & $\begin{array}{r}13 \\
11 \\
15 \\
6 \\
5\end{array}$ & $\begin{array}{r}7 \\
14 \\
18 \\
15 \\
14\end{array}$ & $\begin{array}{r}8 \\
11 \\
4 \\
11 \\
15\end{array}$ & $\begin{array}{l}21 \\
14 \\
23 \\
18 \\
20\end{array}$ & $\begin{array}{l}5 \\
5 \\
6 \\
4 \\
4\end{array}$ & $\begin{array}{l}13 \\
23 \\
27 \\
21 \\
17\end{array}$ & $\begin{array}{l}1 \\
6\end{array}$ \\
\hline $\begin{array}{l}11 \\
12 \\
13 \\
14 \\
15\end{array}$ & $\begin{array}{l}9 \\
1 \\
5 \\
1\end{array}$ & $\begin{array}{l}25 \\
22 \\
27 \\
30 \\
33\end{array}$ & $\begin{array}{r}9 \\
20 \\
8 \\
15 \\
1\end{array}$ & $\begin{array}{l}8 \\
2 \\
2\end{array}$ & $\begin{array}{r}14 \\
10 \\
8 \\
10 \\
15\end{array}$ & $\begin{array}{r}8 \\
9 \\
6 \\
15 \\
21\end{array}$ & $\begin{array}{r}20 \\
24 \\
20 \\
17 \\
5\end{array}$ & $\begin{array}{l}3 \\
4 \\
7 \\
4 \\
5\end{array}$ & $\begin{array}{l}28 \\
24 \\
34 \\
27 \\
20\end{array}$ & 8 \\
\hline $\begin{array}{l}16 \\
17 \\
18 \\
19 \\
20\end{array}$ & 1 & $\begin{array}{l}19 \\
17 \\
\end{array}$ & $\begin{array}{r}11 \\
1 \\
1\end{array}$ & 1 & $\begin{array}{r}15 \\
13 \\
4 \\
9 \\
8\end{array}$ & $\begin{array}{r}16 \\
20 \\
16 \\
7 \\
12\end{array}$ & $\begin{array}{r}16 \\
12 \\
11 \\
7 \\
7\end{array}$ & $\begin{array}{l}5 \\
4 \\
9 \\
3 \\
3\end{array}$ & $\begin{array}{l}40 \\
33 \\
28 \\
21 \\
30\end{array}$ & $\begin{array}{r}15 \\
8 \\
7 \\
4\end{array}$ \\
\hline $\begin{array}{l}21 \\
22 \\
23 \\
24 \\
25\end{array}$ & & $\begin{array}{l}3 \\
2 \\
7\end{array}$ & $\begin{array}{l}1 \\
1\end{array}$ & & $\begin{array}{r}12 \\
13 \\
16 \\
5 \\
7\end{array}$ & $\begin{array}{r}11 \\
7 \\
10 \\
16 \\
3\end{array}$ & $\begin{array}{l}4 \\
9 \\
6\end{array}$ & $\begin{array}{l}3 \\
1 \\
3 \\
2\end{array}$ & $\begin{array}{l}13 \\
37 \\
21 \\
28 \\
24\end{array}$ & $\begin{array}{l}2 \\
2\end{array}$ \\
\hline $\begin{array}{l}26 \\
27 \\
28 \\
29 \\
30\end{array}$ & & $\begin{array}{r}8 \\
2 \\
4 \\
13\end{array}$ & & 1 & $\begin{array}{l}4 \\
3 \\
2 \\
3\end{array}$ & 8 & $\begin{array}{l}6 \\
1\end{array}$ & $\begin{array}{r}4 \\
3 \\
8 \\
2 \\
12\end{array}$ & $\begin{array}{l}27 \\
35 \\
16 \\
19 \\
13\end{array}$ & $\begin{array}{l}1 \\
1\end{array}$ \\
\hline $\begin{array}{l}31 \\
32 \\
33 \\
34 \\
35\end{array}$ & & $\begin{array}{r}5 \\
8 \\
6 \\
1 \\
10\end{array}$ & & & $\begin{array}{l}2 \\
2 \\
7 \\
1 \\
5\end{array}$ & $\begin{array}{l}3 \\
1 \\
1\end{array}$ & 3 & $\begin{array}{r}7 \\
11 \\
1 \\
3\end{array}$ & $\begin{array}{l}16 \\
14 \\
11 \\
14 \\
15\end{array}$ & \\
\hline $\begin{array}{l}36 \\
37 \\
38 \\
39 \\
40\end{array}$ & & $\begin{array}{l}5 \\
1 \\
4\end{array}$ & & & 2 & & * & 4 & $\begin{array}{l}4 \\
1 \\
1\end{array}$ & \\
\hline $\begin{array}{l}41 \\
42 \\
43 \\
44\end{array}$ & & * & $*$ & & * & * & & 1 & * & \\
\hline $\begin{array}{l}45 \\
46 \\
47\end{array}$ & $*$ & & & $*$ & & & & * & & * \\
\hline $\begin{array}{l}\text { Total eggs } \\
\text { deposited }\end{array}$ & 82 & 362 & 151 & 104 & 265 & 246 & 296 & 139 & 732 & 70 \\
\hline
\end{tabular}


Table 19. Number of eggs deposited by ten unmated females of Itoplectis narangae.

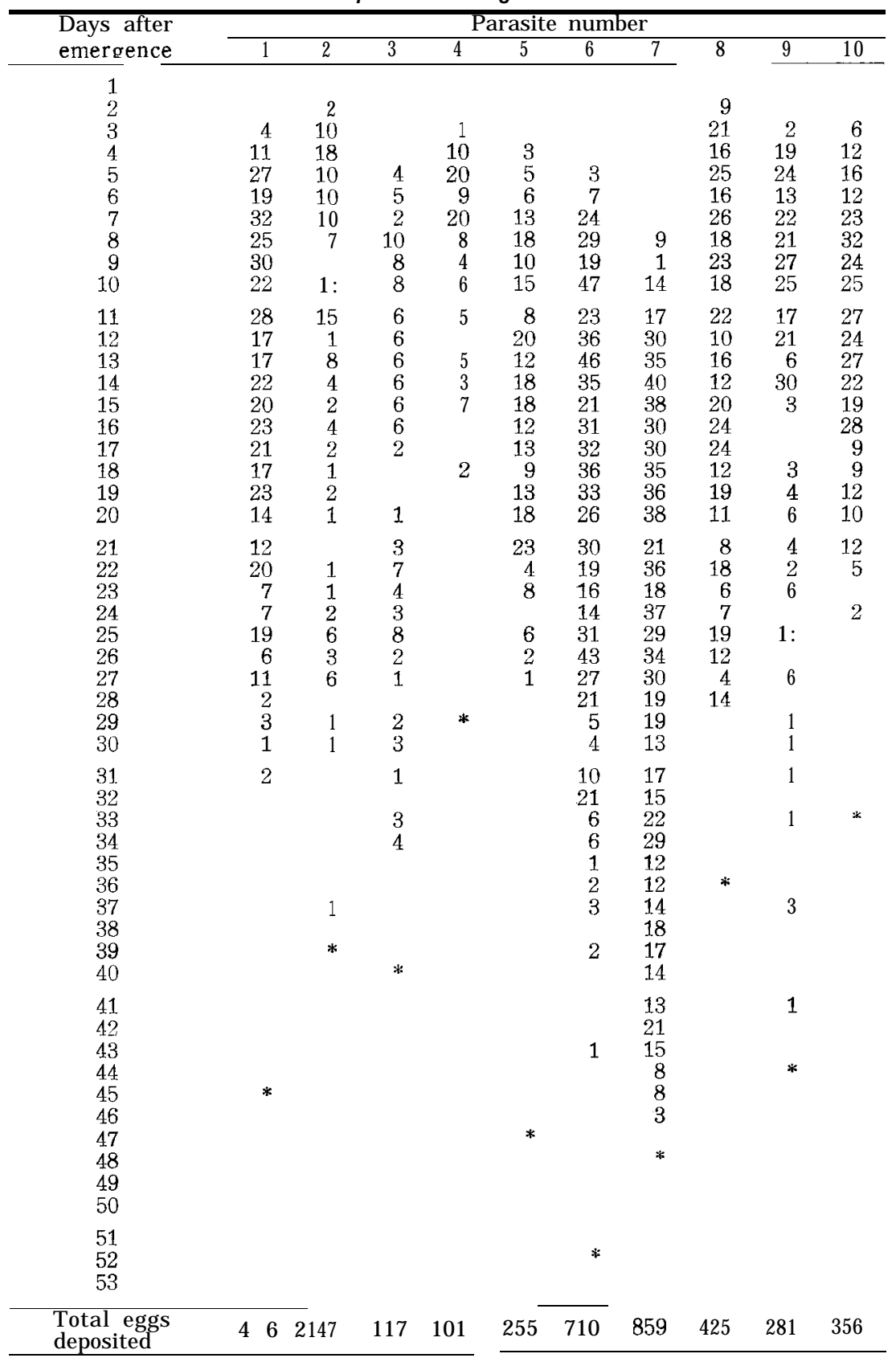

* Asterisk denotes the date of death. 
during the preoviposition period after feeding on honey and water in the container. The preoviposition period was ranging from 1 to 7 days according to the individuals. Upon consulting the above tables together with Tables 23, 24 and 25, it was presumed that the preoviposition period of 1 and 2 days was predominant. The oviposition period varies remarkably between the individuals, being 11 days in the shortest and 39 days in the longest. Large adult female oviposits, in general, a large number of eggs daily from the start of oviposition and its oviposition period is also long. The reverse is true in the smaller one. The highest number of eggs deposited by one female was 859 and the average for the 20 was 300 . The greatest number of eggs deposited by one female in one day was 47.

Nozato (1969) reported that 2 eggs were deposited by a single female per day in Itoplectis cristatae and Arthur (1963) recorded that 39 eggs were deposited per day and 476 eggs were the maximum number of eggs deposited by one female in ltoplectis conquisitor.

Subsequently, it was presumed that the reproductive capacity of this species was larger than the above mentioned species of the same genus.

Tables 20 and 21 indicate the relation between the number of matured eggs deposited and those remained in the ovary of the dead adult female. The number of matured eggs remained in the ovary was always very small, and the percentage of the number of eggs deposited against the estimated total number of ovarian eggs (total number of eggs deposited plus those remained in the ovary) was more than $94.5 \%$.

Table 20. Number of eggs deposited by a single mated female of Itoplectis narangae.

\begin{tabular}{|c|c|c|c|c|c|c|c|c|}
\hline \multirow{2}{*}{$\begin{array}{l}\text { Parasite } \\
\text { number }\end{array}$} & \multicolumn{3}{|c|}{ Number of eggs } & \multirow{2}{*}{$\mathrm{P}$} & \multirow{2}{*}{$\begin{array}{c}\text { No. of } \\
\text { ovarioles }\end{array}$} & \multirow{2}{*}{$\begin{array}{l}\text { Preovi- } \\
\text { position } \\
\text { period }\end{array}$} & \multirow{2}{*}{$\begin{array}{l}\text { Ovipo- } \\
\text { sition } \\
\text { period }\end{array}$} & \multirow{2}{*}{$\begin{array}{c}\text { Longevity } \\
\text { of adult }\end{array}$} \\
\hline & deposited & $\begin{array}{l}\text { Remained } \\
\text { in ovarv }\end{array}$ & Total & & & & & \\
\hline 1 & 82 & 1 & 83 & $99.2 \%$ & 37 & 3 & 13 & 45 \\
\hline 2 & 362 & 6 & 368 & 98.7 & 14 & 4 & 35 & 41 \\
\hline 3 & 151 & 0 & 151 & 100.0 & 16 & 2 & 20 & 44 \\
\hline 4 & 104 & & 101 & & & 1 & 27 & 45 \\
\hline 5 & 265 & 0 & 265 & 100.0 & 18 & 4 & 32 & 41 \\
\hline 6 & 246 & 0 & 245 & 100.0 & 22 & 4 & 31 & 44 \\
\hline 7 & 296 & & 296 & & & 2 & 32 & 39 \\
\hline 8 & 139 & 1 & 140 & 99. 3 & 16 & 4 & 37 & 45 \\
\hline 9 & 732 & 16 & 748 & 97.9 & 18 & 2 & 36 & 42 \\
\hline 10 & 70 & 1 & 71 & 98.6 & 17 & 4 & 36 & 46 \\
\hline
\end{tabular}

P: Percentage of deposited egg number against the estimated whole ovarian egg number (total number of eggs deposited and remained in ovary). 
Table 21. Number of eggs deposited by a single unmated female of Itoplectis narangae.

\begin{tabular}{|c|c|c|c|c|c|c|c|c|}
\hline \multirow{2}{*}{$\begin{array}{l}\text { Parasite } \\
\text { number }\end{array}$} & \multicolumn{3}{|c|}{ Number of eggs } & \multirow{2}{*}{$\mathrm{P}$} & \multirow{2}{*}{$\begin{array}{l}\text { No. of } \\
\text { ovarioles }\end{array}$} & \multirow{2}{*}{$\begin{array}{l}\text { Preovi- } \\
\text { position } \\
\text { period }\end{array}$} & \multirow{2}{*}{$\begin{array}{l}\text { Ovipo- } \\
\text { sition } \\
\text { period }\end{array}$} & \multirow{2}{*}{$\begin{array}{c}\text { Longevity } \\
\text { of adult }\end{array}$} \\
\hline & $\overline{\text { deposited }}$ & $\begin{array}{l}\text { Remained } \\
\text { in ovary }\end{array}$ & Total & & & & & \\
\hline 1 & 462 & 3 & 465 & $\begin{array}{r}90 \\
99.4\end{array}$ & 23 & 2 & 29 & 45 \\
\hline 2 & 147 & 2 & 149 & 98.6 & 15 & 1 & 36 & 39 \\
\hline 3 & 117 & 7 & 124 & 94.5 & 15 & 4 & 30 & 40 \\
\hline 4 & 101 & 3 & 104 & 99.1 & 18 & 2 & 16 & 29 \\
\hline 5 & 255 & 1 & 256 & 99.7 & 15 & 3 & 24 & 47 \\
\hline 6 & 710 & 13 & 723 & 97.2 & 23 & 4 & 38 & 52 \\
\hline 7 & 859 & 6 & 865 & 99.9 & 23 & 7 & 39 & 48 \\
\hline 8 & 425 & 3 & 428 & 99.9 & 21 & 1 & 27 & 36 \\
\hline 9 & 283 & & 281 & - & - & 2 & 39 & 49 \\
\hline 10 & 356 & 6 & 362 & 99.6 & 18 & 2 & 22 & 33 \\
\hline
\end{tabular}

P: Percentage of deposited egg number against the estimated whole ovarian egg number (total number of eggs deposited and remained in ovary)

\section{Fluctuation of oviposition,}

The data of Tables 18 and 19 are adjusted so as to make easy to understand or to compare with the data in Table 22 and Fig. 14.

Namely, in this table the oviposition of all the females was adjusted to be started on the same day. As shown in Table 22 and Fig. 14, it may be seen that the number of eggs deposited increased rapidly from the date of oviposition started and reaches the peak on the sixth day, and active oviposition continues for the first 14 to 21 days and decreases gradually thereafter. The daily fluctuation shows the continuation of increase and decrease and vice versa. The number of eggs deposited per day is not the same. It is felt that this is probably attributable to the physiological control of the parasite itself. Four parasites out of 10 unmated females oviposited more than 400 eggs, about $70 \%$ of which were oviposited for 21 days after the start of oviposition, and the other 6 parasites oviposited less than 400 eggs, about $85 \%$ of which were oviposited during the same period. This fact must be noticed to be important to facilitate this species an efficient oviposition in making mass production.

\section{Relation between the size of parasite and fecundity.}

The effect of the size of parasite on the number of eggs deposited have been reported occasionally (Salt 1940, Flanders 1935, Yasumatsu and Yamamoto 1953, Nohara 1956, Shiga and Nakanishi 1968, etc.). 
Table 22. Number of eggs deposited daily by ten mated and ten unmated females of Itoplectis narangae.

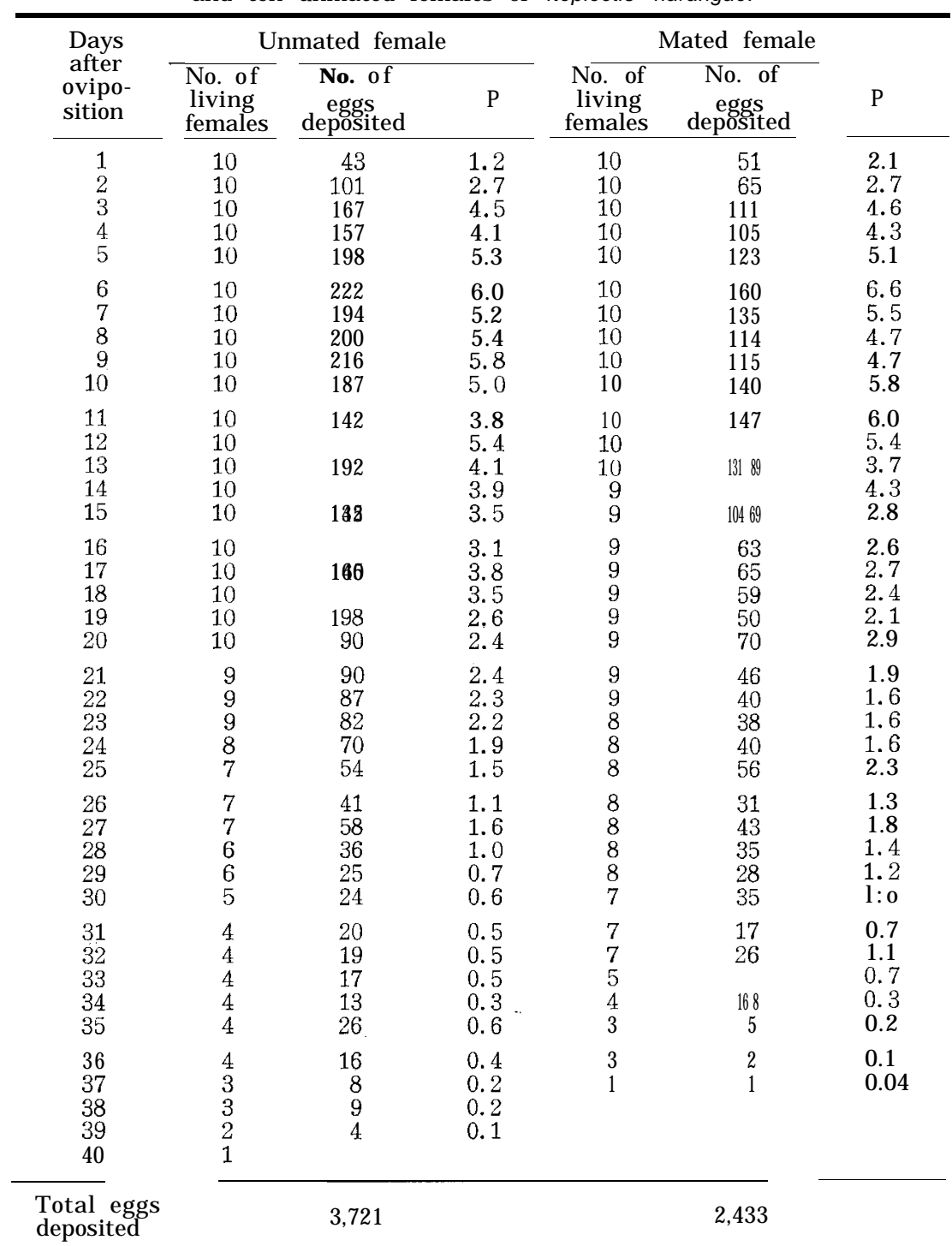

P: Percentage of daily deposited egg number to the total number of eggs deposited by all females. 


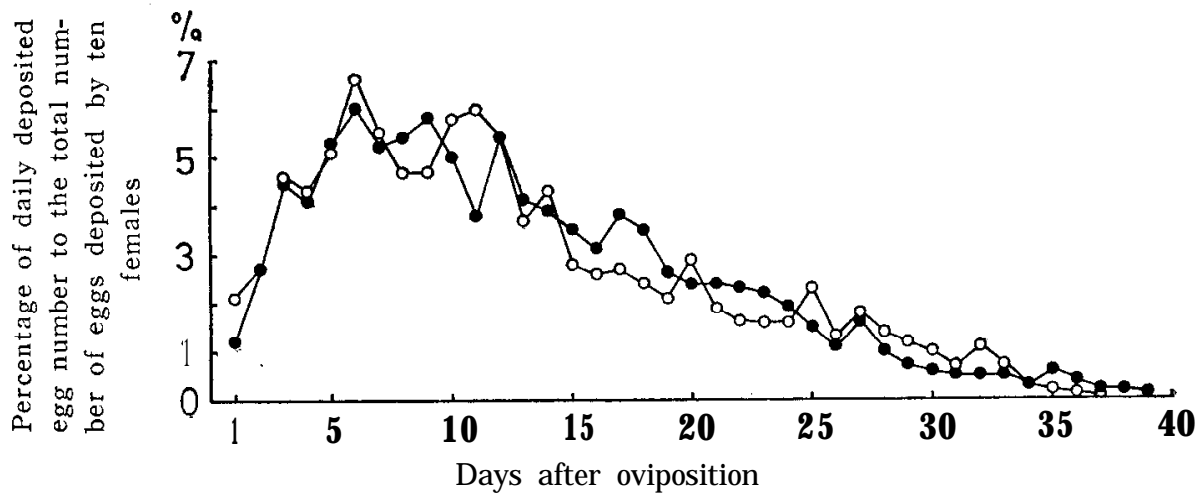

Fig. 14. Oviposition curves of mated (hollow circle) and unmated (solid circle) female of Itoplectisnarangae.

Fig. 15 illustrates the relationship between the size and fecundity of 20 females used for experiments (Tables 18 and 19). The size of the adult females is represented by the length of forewing for the sake of convenience. As seen in the figure, high positive correlation of $r=$ 0.660 was observed between the fecundity and the size of this species (significant at $1 \%$ level).

\section{Relation between the size of parasite and the number of ovarioles.}

The size of this species is affected by the species, size, age in days and other factors of the hosts.

The frequency distribution of the number of ovarioles is very wide according to the parasites. The results of investigation based on the data presented in Table 16 are illustrated in Fig. 16. The difference of the number of ovarioles within the individual parasite was remarkable ranging from 11 to 28 . This agrees with the data observed by Iwata (1960). Among the 100 parasites investigated about $25 \%$ had the ovarioles 18 and 19 in number, and about $25 \%$ showed a symmetrical distribution in the number of left and right ovarioles. As shown in Fig. 17 the relation between the size of parasites and the number of ovarioles was $\mathrm{r}=0.167$, indicating almost no correlation between them. Therefore, it seems that the effect of the fecundity by the size of parasite has no relation to the number of ovarioles.

VIII. Effect of the period of lacking hosts on the number of eggs deposited

Synovigenic species (Flanders 1935) ceases the oögenesis of parasites 


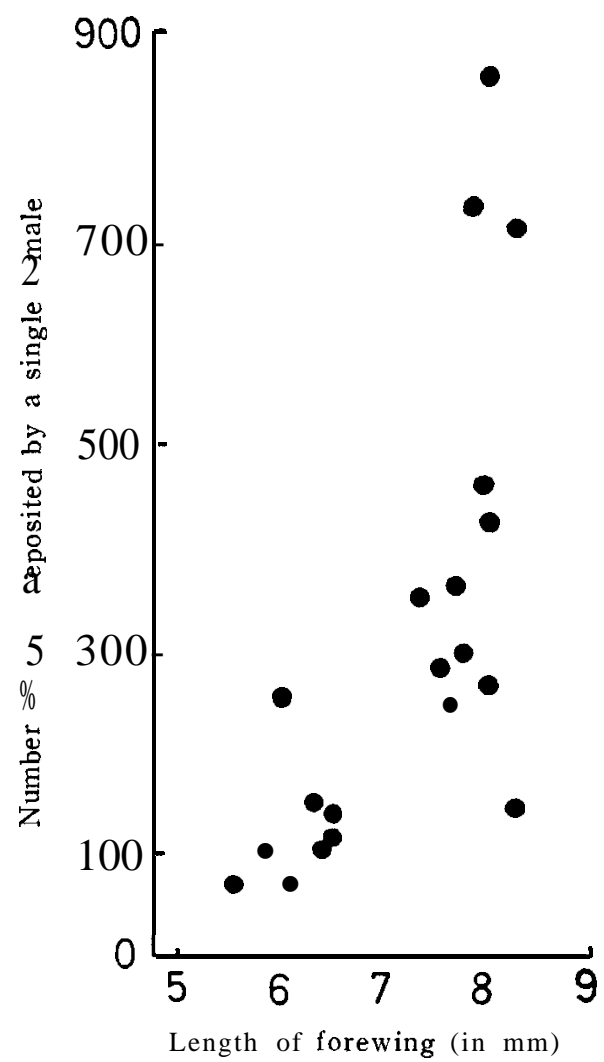

Fig. 15. Relation between the length of forewing and the number of eggs deposited by a single female.

if hosts are not available for oviposition and the matured eggs in the ovaries are absorbed. The oijsorption phenomenon is helpful for the maintenance of reproductive capacity of the parasites and the conservation of reproductive material is related to high searching capacity (Flanders 1950). The oijsorption phenomenon of the parasites is very significant from the point of view of biological control, and there are many instances of successful results in biological control with such parasites (Flanders 1942, Yasumatsu 1953, etc.).

The author conducted the following experiments in order to investigate the ability to maintain the reproductive capacity during the long period of absence of suitable hosts.

Methods: Three groups of 10,6 and 10 parasites were given hosts for oviposition for the first 5 days from the date of oviposition started, thereafter each group was withheld from hosts for 10, 15 and 20 days, 


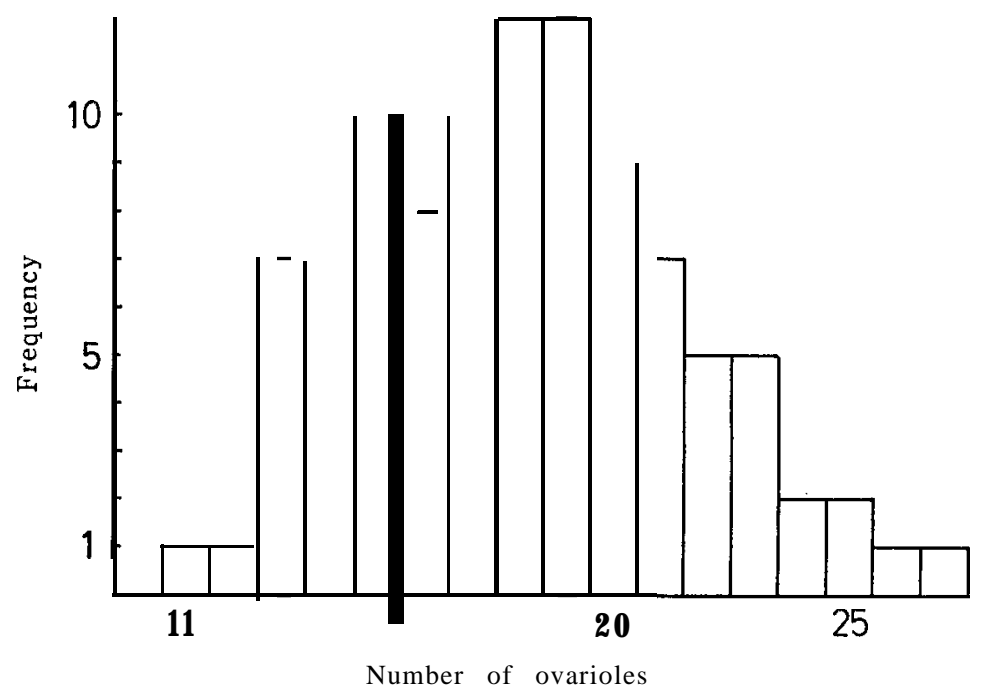

Fig. 16. Frequency distribution of the number of ovarioles of Itoplectis narangae.

respectively, and then were given hosts again for oviposition. Three host pupae of Galleriamellonella were given daily and the pupae are renewed every 24 hours and then the hosts were dissected to count the number of eggs deposited under a binocular microscope. The adult females were fed with undiluted honey and water and the Container A was used for the laboratory experiments in a $25^{\circ} \mathrm{C}$ insectary.

Results : The results of these experiments are presented in Tables 23, 24, 25, 26, 27 and 28 and Fig. 18.

In every group this species responded rapidly to a given host after each of 10,15 or 20 day absence of hosts and began to lay eggs immediately. The number of eggs laid on the first day was the largest in those which were not given hosts for 10 days and fewer in order of those which were not given hosts for 15 and 20 days. The number of eggs laid on the second day decreased markedly in comparison with the first day and recovered slowly from the third day. It reached the peak on the fifth day and then began to decrease gradually. It is felt that those matured eggs which remained unabsorbed in the ovaries were probably oviposited on the first day. Therefore, it may be seen that the o\&sorption is enhanced as the non-host period is prolonged and matured eggs remained in the ovaries decreased gradually as the period of lacking hosts is lengthened. A remarkable decrease of the number of eggs laid on the second day is probably explained by the fact that the immature eggs remained in the ovaries require usually more than 


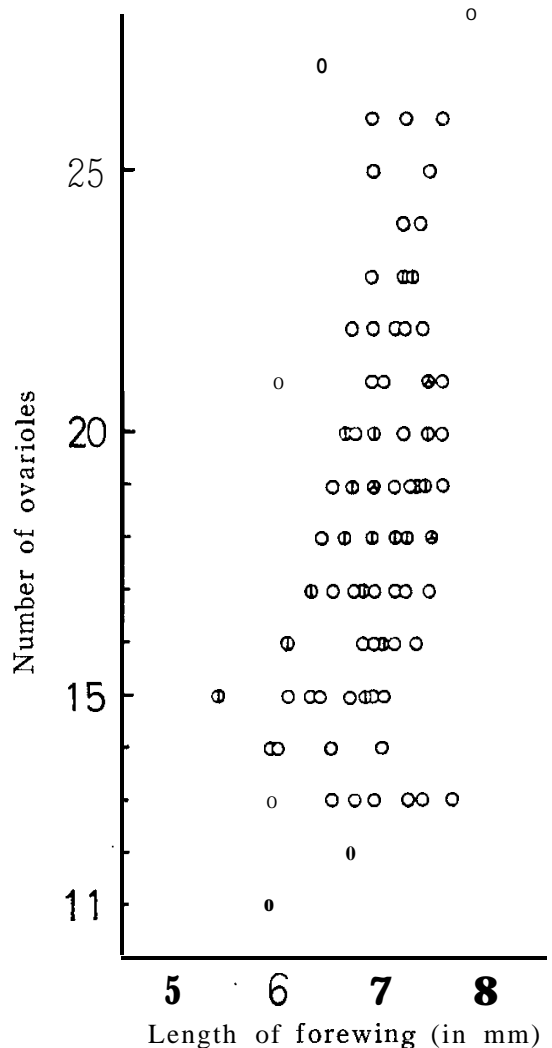

Fig. 17. Relation between the length of forewing and the number of ovarioles of Itoplectis narangae.

Table 23. Number of eggs laid when hosts were given after being withheld from hosts for 10 days during the oviposition period.

\begin{tabular}{|c|c|c|c|c|c|c|c|c|c|c|}
\hline \multirow{2}{*}{$\begin{array}{c}\text { Days } \\
\text { after } \\
\text { emergence }\end{array}$} & \multicolumn{10}{|c|}{ Parasite number } \\
\hline & 1 & 2 & 3 & 4 & 5 & 6 & 7 & 8 & 9 & 10 \\
\hline $\begin{array}{r}1 \\
2 \\
3 \\
4 \\
5 \\
6 \\
7 \\
8 \\
9 \\
/ 1\end{array}$ & $\begin{array}{r}2 \\
4 \\
13 \\
21 \\
24\end{array}$ & $\begin{array}{r}2 \\
8 \\
15 \\
23 \\
39\end{array}$ & $\begin{array}{r}1 \\
4 \\
9 \\
18 \\
33\end{array}$ & $\begin{array}{r}3 \\
5 \\
7 \\
18 \\
26\end{array}$ & $\begin{array}{r}1 \\
7 \\
10 \\
45 \\
34\end{array}$ & $\begin{array}{r}1 \\
5 \\
26 \\
22 \\
30\end{array}$ & $\begin{array}{r}1 \\
10 \\
16 \\
39 \\
37\end{array}$ & $\begin{array}{r}1 \\
7 \\
11 \\
14 \\
29\end{array}$ & $\begin{array}{r}3 \\
16 \\
20 \\
34 \\
40\end{array}$ & $\begin{array}{r}1 \\
5 \\
18 \\
27 \\
36\end{array}$ \\
\hline
\end{tabular}




\begin{tabular}{|c|c|c|c|c|c|c|c|c|c|c|}
\hline \multirow{2}{*}{$\begin{array}{c}\text { Days } \\
\text { after } \\
\text { emergence }\end{array}$} & \multicolumn{10}{|c|}{ Parasite number } \\
\hline & 1 & 2 & 3 & 4 & 5 & 6 & 7 & 8 & 9 & 10 \\
\hline $\begin{array}{l}16 \\
17 \\
18 \\
19 \\
20 \\
21 \\
22 \\
23 \\
24 \\
25\end{array}$ & $\begin{array}{r}15 \\
5 \\
9 \\
19 \\
13 \\
1 \\
1 \\
2\end{array}$ & $\begin{array}{r}11 \\
1 \\
11 \\
8 \\
2 \\
24 \\
22 \\
20\end{array}$ & $\begin{array}{r}11 \\
4 \\
11 \\
20 \\
18 \\
22 \\
28 \\
25 \\
16\end{array}$ & $\begin{array}{r}14 \\
3 \\
7 \\
17 \\
22 \\
27 \\
28 \\
15 \\
18\end{array}$ & $\begin{array}{r}10 \\
4 \\
14 \\
20 \\
15 \\
32 \\
11 \\
18 \\
19\end{array}$ & $\begin{array}{r}8 \\
6 \\
8 \\
11 \\
9 \\
13 \\
6 \\
4\end{array}$ & $\begin{array}{r}16 \\
2 \\
12 \\
19 \\
23 \\
20 \\
12 \\
20\end{array}$ & $\begin{array}{r}10 \\
3 \\
12 \\
11 \\
11 \\
4 \\
6 \\
12 \\
19\end{array}$ & $\begin{array}{r}28 \\
23 \\
8 \\
20 \\
18\end{array}$ & $\begin{array}{r}16 \\
9 \\
5\end{array}$ \\
\hline $\begin{array}{l}26 \\
27 \\
28 \\
29 \\
30 \\
31 \\
32 \\
33 \\
34 \\
35\end{array}$ & $*$ & $\begin{array}{r}17 \\
8 \\
11 \\
14 \\
14 \\
7 \\
1 \\
7 \\
10 \\
7\end{array}$ & $\begin{array}{r}30 \\
21 \\
17 \\
13 \\
24 \\
8 \\
5 \\
5 \\
2 \\
1\end{array}$ & $\begin{array}{r}12 \\
14 \\
18 \\
16 \\
8 \\
9 \\
15 \\
17 \\
18 \\
10\end{array}$ & $\begin{array}{r}24 \\
12 \\
12 \\
10 \\
12 \\
10 \\
14 \\
3 \\
4 \\
9\end{array}$ & $\mathrm{x}$ & $\begin{array}{r}23 \\
13 \\
8 \\
9 \\
19 \\
6 \\
1 \\
3 \\
4\end{array}$ & $\begin{array}{r}14 \\
14 \\
12 \\
17 \\
15 \\
23 \\
10 \\
17 \\
9 \\
4\end{array}$ & $\begin{array}{l}16 \\
16 \\
21 \\
23 \\
23 \\
24 \\
11 \\
18 \\
22 \\
18\end{array}$ & \\
\hline $\begin{array}{l}36 \\
37 \\
38 \\
39 \\
40 \\
41 \\
42 \\
43 \\
44 \\
45\end{array}$ & & $\begin{array}{r}7 \\
3 \\
3 \\
4 \\
3 \\
5 \\
10 \\
5 \\
5 \\
5\end{array}$ & $\begin{array}{l}4 \\
3 \\
1 \\
1\end{array}$ & $\begin{array}{r}1 \\
17 \\
7\end{array}$ & $\begin{array}{l}8 \\
4 \\
4 \\
3 \\
2 \\
7 \\
4 \\
5\end{array}$ & & $\begin{array}{l}3 \\
2 \\
2\end{array}$ & $\begin{array}{l}3 \\
7 \\
2\end{array}$ & $\begin{array}{r}28 \\
1 \\
9 \\
8\end{array}$ & \\
\hline $\begin{array}{l}46 \\
47 \\
48 \\
49 \\
50 \\
51 \\
52 \\
53 \\
54 \\
55\end{array}$ & & $\begin{array}{l}3 \\
1\end{array}$ & & $\begin{array}{l}1 \\
1\end{array}$ & * & & $*$ & & 8 & \\
\hline $\begin{array}{l}56 \\
57 \\
58 \\
59 \\
60 \\
61 \\
62 \\
63 \\
64\end{array}$ & & & & & & & & & & \\
\hline
\end{tabular}

* Asterisk denotes the date of death.

$x$ Mark denotes the date of death by the abnormal distension of the abdomen, 
Table 24. Number of eggs laid when hosts were given after being withheld from hosts for 15 days during the oviposition period.

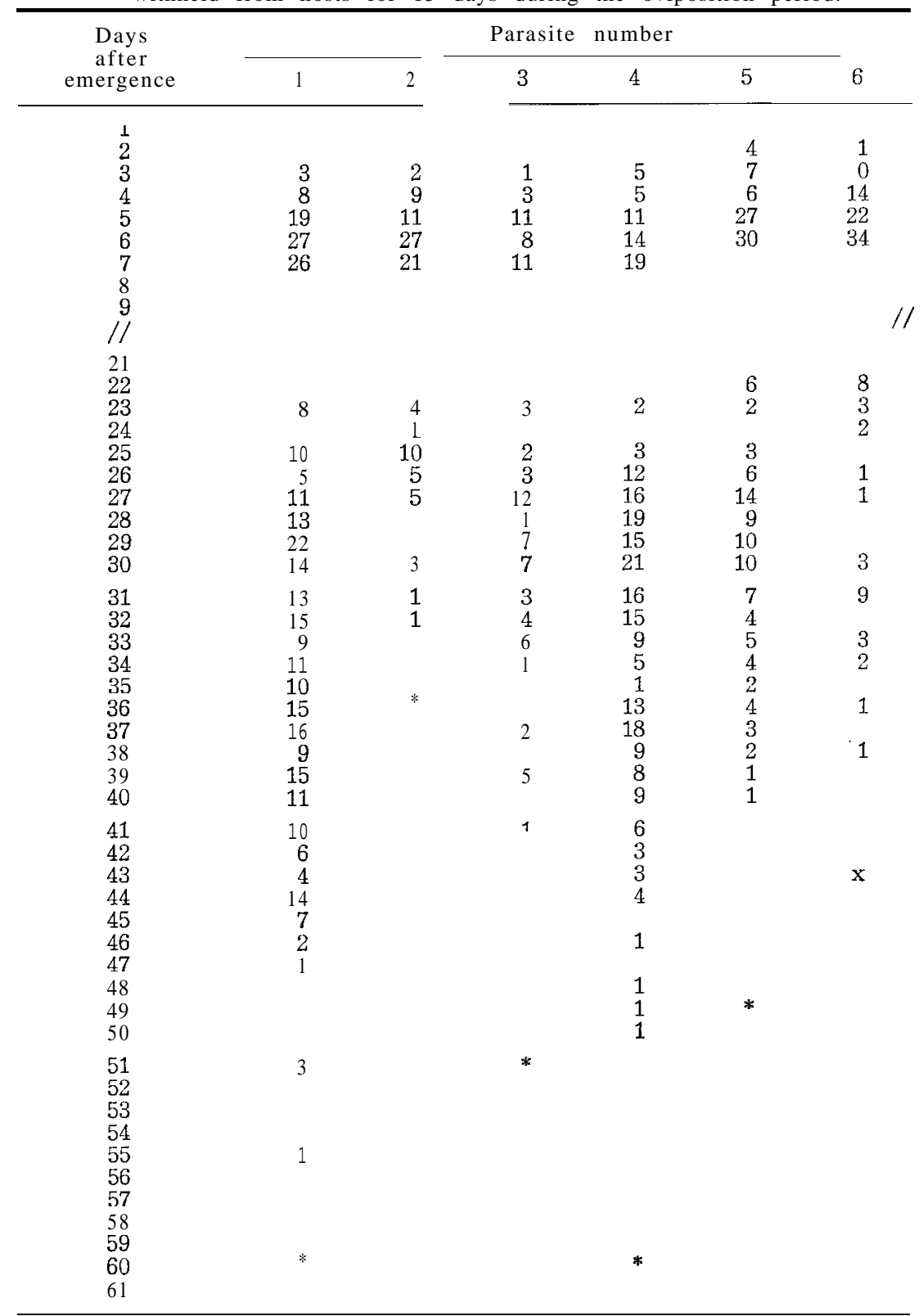

* Asterisk denotes the date of death.

$\mathbf{x}$ Mark denotes the date of death by the abnormal distension of the abdomen. 
Table 25. Number of eggs laid when hosts were given after being withheld from hosts for 20 days during the oviposition period.

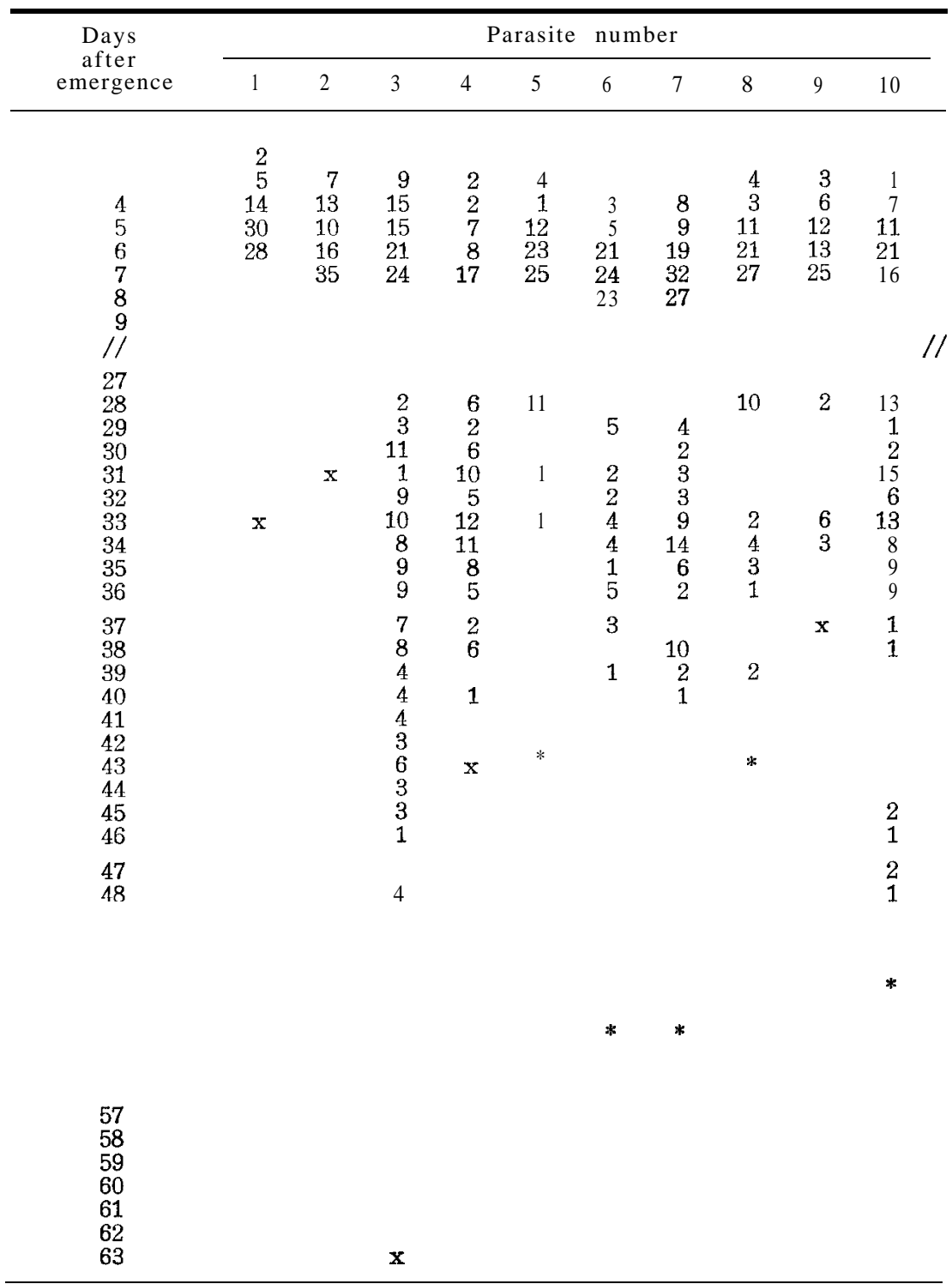

* Asterisk denotes the date of death.

$\mathbf{x}$ Mark denotes the date of death by the abnormal distension of the abdomen. 
Table 26. Number of eggs laid when hosts were given after being withheld from hosts for 10 days during the oviposition period

\begin{tabular}{|c|c|c|c|c|c|c|c|}
\hline $\begin{array}{l}\text { Parasite } \\
\text { number }\end{array}$ & $\begin{array}{l}\text { Fore- } \\
\text { wing } \\
\text { length }\end{array}$ & $\begin{array}{l}\text { Total } \\
\text { no. of } \\
\text { eggs } \\
\text { laid }\end{array}$ & $\begin{array}{l}\text { No. of eggs } \\
\text { laid after } \\
\text { being with- } \\
\text { held from } \\
\text { hosts for } \\
10 \text { days }\end{array}$ & $\begin{array}{l}\text { Oviposition } \\
\text { period after } \\
\text { being with- } \\
\text { held from } \\
\text { hosts for } \\
10 \text { days }\end{array}$ & $\begin{array}{c}\text { No. of } \\
\text { ovarioles }\end{array}$ & $\begin{array}{l}\text { No. of } \\
\text { matured } \\
\text { eggs in } \\
\text { ovaries }\end{array}$ & $\begin{array}{l}\text { Lon- } \\
\text { gevity }\end{array}$ \\
\hline 1 & 6.7 & 129 & 65 & 8 & 15 & 0 & 30 \\
\hline 2 & 6.9 & 336 & 249 & 30 & 17 & 0 & 53 \\
\hline$* 3$ & 7.2 & 355 & 290 & 24 & 23 & 1 & 43 \\
\hline 4 & 7.2 & 377 & 318 & 32 & & _ & 64 \\
\hline 5 & 7.7 & 387 & 290 & 27 & 15 & & 46 \\
\hline$* 6$ & 6.6 & 149 & 65 & 8 & 16 & 1 & 31 \\
\hline 7 & 7.1 & 333 & 230 & 27 & & & 50 \\
\hline 8 & 6.6 & 297 & 235 & 23 & 15 & - & 42 \\
\hline 9 & 7.5 & 572 & 459 & 34 & 20 & 3 & 53 \\
\hline 10 & 7.0 & 117 & 30 & 3 & 17 & - & 21 \\
\hline
\end{tabular}

* Asterisk denotes the parasite death by the abnormal distension of the abdomen.

Tabe 27. Number of eggs laid when hosts were given after being withheld from hosts for 15 days during the oviposition period.

\begin{tabular}{|c|c|c|c|c|c|c|c|}
\hline $\begin{array}{c}\text { Parasite } \\
\text { number }\end{array}$ & $\begin{array}{l}\text { Fore- } \\
\text { wing } \\
\text { length }\end{array}$ & $\begin{array}{l}\text { Total } \\
\text { no. of } \\
\text { eggs } \\
\text { laid }\end{array}$ & $\begin{array}{l}\text { No. of egg } \\
\text { laid after } \\
\text { being with- } \\
\text { held from } \\
\text { hosts for } \\
15 \text { days }\end{array}$ & $\begin{array}{l}\text { s Oviposition } \\
\text { period after } \\
\text { being with- } \\
\text { held from } \\
\text { hosts for } \\
15 \text { days }\end{array}$ & $\begin{array}{c}\text { No. of } \\
\text { ovarioles }\end{array}$ & $\begin{array}{l}\text { No. of } \\
\text { matured } \\
\text { eggs in } \\
\text { ovaries }\end{array}$ & $\begin{array}{l}\text { Lon- } \\
\text { gevity }\end{array}$ \\
\hline 1 & 7.7 & 337 & 254 & 33 & 17 & 5 & 60 \\
\hline 2 & 6.9 & 98 & 30 & 10 & & & 36 \\
\hline 3 & 5.8 & 93 & 59 & 23 & 10 & 0 & 51 \\
\hline 4 & 5.7 & 265 & 211 & 28 & 16 & 0 & 60 \\
\hline 5 & 6.3 & 168 & 94 & 20 & 17 & 0 & 49 \\
\hline$* 6$ & 7.2 & 105 & 34 & 17 & 18 & 4 & 43 \\
\hline
\end{tabular}

* Asterisk denotes the parasite death by the abnormal distension of the abdomen.

24 hours to become mature eggs following the host feeding after the oviposition of mature eggs. Subsequently the number of eggs to be laid increases gradually. Taking into consideration the size of the parasites, the number of eggs deposited and the oviposition period as previously mentioned, there is a tendency that the larger the adult females the more the number of eggs deposited. This tendency may be also observed in the oviposition when hosts were not given for 10, 15 and 20 days respectively. Although the oviposition period is related 
Table 28. Number of eggs laid when hosts were given after being withheld from hosts for 20 days during the oviposition period.

\begin{tabular}{|c|c|c|c|c|c|c|c|}
\hline $\begin{array}{l}\text { Parasite } \\
\text { number }\end{array}$ & $\begin{array}{l}\text { Fore- } \\
\text { wing } \\
\text { length }\end{array}$ & $\begin{array}{l}\text { Total } \\
\text { no. of } \\
\text { eggs } \\
\text { laid }\end{array}$ & $\begin{array}{l}\text { No. of egg. } \\
\text { laid after } \\
\text { being with- } \\
\text { held from } \\
\text { hosts for } \\
20 \text { days }\end{array}$ & $\begin{array}{c}\text { S Oviposition } \\
\text { period after } \\
\text { being with- } \\
\text { held from } \\
\text { hosts for } \\
20 \text { days }\end{array}$ & $\begin{array}{c}\text { No. of } \\
\text { ovarioles }\end{array}$ & $\begin{array}{l}\text { No. of } \\
\text { matured } \\
\text { eggs in } \\
\text { ovaries }\end{array}$ & $\begin{array}{l}\text { d Lon- } \\
\text { gevity }\end{array}$ \\
\hline 1 & 6.9 & 79 & & & 15 & $\overline{5}$ & 33 \\
\hline$* 0$ & 6.4 & 81 & & & & & 31 \\
\hline 3 & 7.1 & 194 & 110 & 23 & 16 & & 63 \\
\hline$: 1$ & 6.0 & 110 & 74 & 13 & 12 & & 43 \\
\hline 5 & 7.2 & 78 & 13 & 6 & 14 & & 43 \\
\hline 6 & 4.1 & 103 & 27 & 11 & 16 & & 54 \\
\hline 7 & 7.3 & 151 & 56 & 12 & 23 & & 54 \\
\hline 8 & 6.7 & 88 & 22 & 12 & 13 & & 43 \\
\hline$: y$ & 6.8 & 70 & 11 & 7 & 16 & 15 & 37 \\
\hline 10 & 6.3 & 140 & 91 & 21 & 19 & & 52 \\
\hline
\end{tabular}

: Asterisk denotes the parasite death by the abnormal distension of the abdomen.

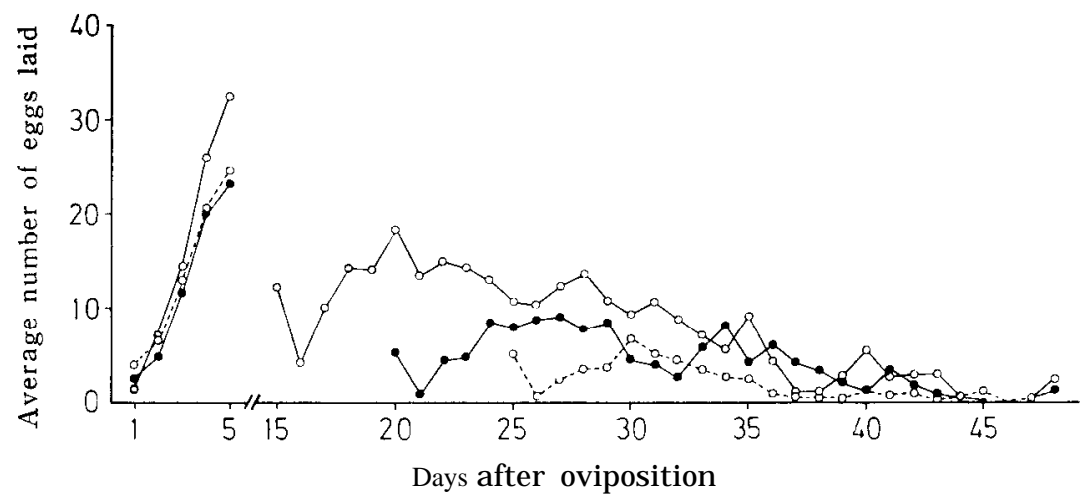

Fig. 38. Oviposition curve when hosts were given after being withheld from hosts for 10, 15 and 20 days during the oviposition period. 10 parasites withheld from hosts for 10 days.
6 parasites withheld from hosts for 15 days.
10 parasites withheld from hosts fos 20 days.

to the number of egg deposited per day, it tends to be prolonged as the number of egg deposits increases.

It is very difficult to compare the results obtained on the longevity of the parasites in this experiment with that of those made in the previous one (Chapter VII, Tables 20 and 21), because the number of 


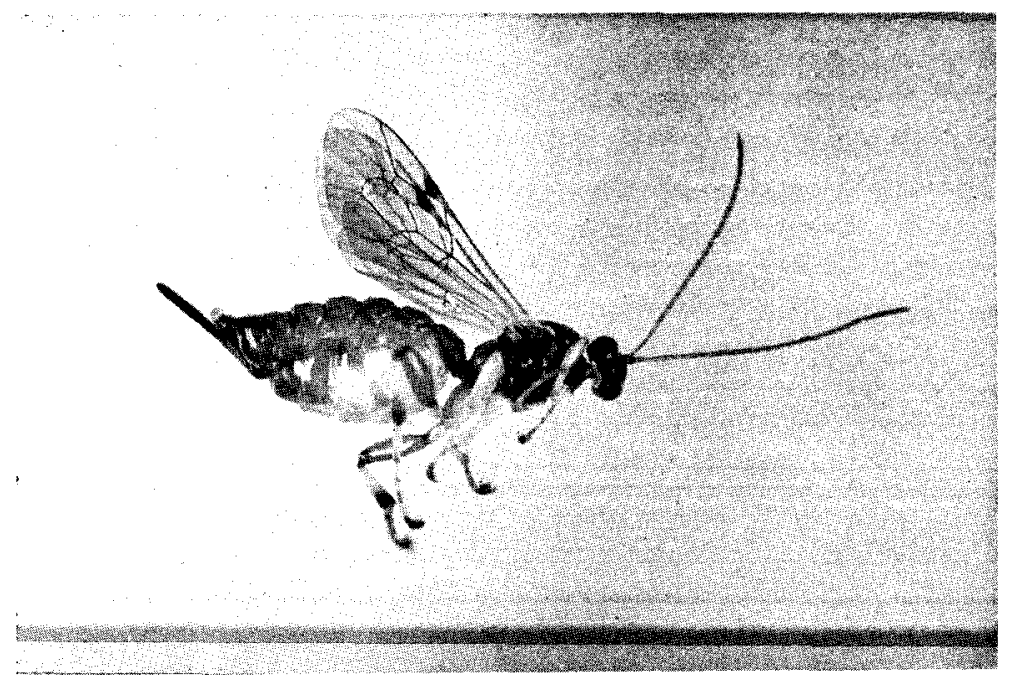

Fig. 19. The dead Itoplectis narangae by the abnormal distension of the abdomen.

parasites investigated was limited and there were also observed some dead parasites, as shown in Fig. 19, which seemed to be caused by the abnormal distension of the abdomen during the present experiments, but not by the natural death. Although these parasites may oviposit for one or two more days after the proceeding of distension, the number of egg deposited decreases sharply in comparison with that laid in the normal state. Even though the oviposition behavior may be observed on the third or fourth day, the abnormal distension of the abdomen interrupts actual oviposition, and finally, the parasites die almost on the fifth or sixth day. The cause of such distension is not clearly known. The result of dissection of the dead parasites revealed that the distended abdomen was filled with gas and the ovaries of some parasites were hardly discriminated. If these parasites were excluded, the mean longevity of the 20 parasites which were laying eggs daily (Tables 20 and 21) was 42.3 days, while those which were not given hosts for 10 days lived for 44.8 days and those not given hosts for 15 or 20 days survived for 49.8 days. Although the latter seems to survive somewhat for a longer period, it is not certain whether such longevity is attributable to either the difference among the individual parasites or the period during which the host pupae were not given.

As seen from the results of the present experiments and Tables 18 and 19, there were many individuals of this species which survived for a long period even after the stop of oviposition. Flanders (1942) stated that oögenesis is in many, if not most anhydropic species of 
Hymcnoptera may proceed without interruption until the death of the female. Contrary to the statement of Flanders the females of this ichneumon fly may survive much longer period even after the completion of oviposition, and it seems that such females still maintain their potential reproductive capacity. But, actually they did not oviposit. Discontinuation of oviposition may indicate that the capacity of making oögenesis was declining as the age in day advances.

\section{Longevity of adult}

The longevity of adult parasites depends largely upon the species, temperatures, diets, oviposition, illumination time and meteorological conditions. It is important for practical purposes to know the longevity of adult parasites under different conditions.

Methods: Males and females were studied separately at constant temperatures of $25^{\circ} \mathrm{C}$ (insectary), $30^{\circ} \mathrm{C}$ (phytotron) and $33^{\circ} \mathrm{C}$ (phytotron) when fed with different diets. Twenty individuals of each sex were observed at each temperature. In the phytotron the parasites were not exposed to the direct rays of the sun. Each one of the parasites was put in the petri dish of $9.5 \mathrm{~cm}$ in diameter and $1.8 \mathrm{~cm}$ in depth, the mouth of the petri dish being covered with gauze and tied up with rubber bands. Undiluted honey was given for diet once in 3 or 4 days and water was also given once every day to the absorbent cotton attached to the inside of the petri dish. The container was renewed once in 10 days to prevent contamination.

Results : The results of this experiment are presented in Table 29. Although it is somewhat difficult to derive the conclusion from the results definitely due to the limited number of parasites investigated, general tendency may be understood. The longevity of the adult parasites became shorter gradually as temperature rose. A great differ-

Table 29. Mean longevity in days of the adult Ztoplectis narangae at different temperatures when fed with different diets.

(Means based on 20 observations.)

\begin{tabular}{|c|c|c|c|c|c|}
\hline \multirow{2}{*}{$\begin{array}{l}\text { Temp. of } \\
\text { rearing } \\
\text { room }\end{array}$} & \multirow{2}{*}{$S$ e $x$} & \multicolumn{4}{|c|}{ Diets } \\
\hline & & None & Water & Honey & $\begin{array}{c}\text { Honey \& } \\
\text { water }\end{array}$ \\
\hline $25^{\circ} \mathrm{C}$ & $\begin{array}{l}\mathrm{a} \\
\text { 우 }\end{array}$ & $\begin{array}{l}5.8 \\
5.7\end{array}$ & $\begin{array}{l}7.8 \\
7.1\end{array}$ & $\begin{array}{l}13.5 \\
26.0\end{array}$ & $\begin{array}{l}36.1 \\
46.8\end{array}$ \\
\hline $30^{\circ} \mathrm{C}$ & 9 & 2.8 & $\begin{array}{l}4.9 \\
4.9\end{array}$ & $\begin{array}{l}3.0 \\
4.8\end{array}$ & $\begin{array}{l}24.8 \\
23.6\end{array}$ \\
\hline $33^{\circ} \mathrm{C}$ & $\begin{array}{l}3 \\
0 \\
0\end{array}$ & $\begin{array}{l}2.7 \\
3.0\end{array}$ & $\begin{array}{l}4.4 \\
4.0\end{array}$ & $\begin{array}{l}2.4 \\
4.7\end{array}$ & $\begin{array}{l}23.8 \\
17.5\end{array}$ \\
\hline
\end{tabular}


ence was observed between $25^{\circ} \mathrm{C}$ and $30^{\circ} \mathrm{C}$, while it was not so between $30^{\circ} \mathrm{C}$ and $33^{\circ} \mathrm{C}$. When the parasites were unfed or fed with water only, the longevity of the male was a little longer than that of the female. It seems that the water supply was helpful to extend the longevity of the parasites. The undiluted honey was also helpful for the extension of the longevity of the adult parasites markedly at $25^{\circ} \mathrm{C}$, while it was shorter at $30^{\circ} \mathrm{C}$ and $33^{\circ} \mathrm{C}$, respectively, than that of the parasites fed with water. The longest survival period when undiluted honey and water were given was 52 days in the male and 63 days in the female at $25^{\circ} \mathrm{C} ; 41$ days in the male and 33 days in the female at $30^{\circ} \mathrm{C}$; and 40 days in the male and 35 days in the female at $33^{\circ} \mathrm{C}$. It may be presumed that such an ability of prolonged survival under relatively high temperature of $33^{\circ} \mathrm{C}$ may explain clearly the wide distribution of this species. The mean longevity of 20 adult females fed daily with undiluted honey, water and given hosts was 42 days under $25^{\circ} \mathrm{C}$ condition (Tables 18 and 19), and that of the adult females fed with undiluted honey and water was 46.8 days without hosts under the same temperature condition. This may suggest that the host fluid is not essential for the maintenance of life of the adult parasites (Edward 1954).

It may be presumed from these observations that the survival period of this species is probably longer under favorable field conditions than the mean value of the present experiments at the constant temperatures.

\section{$X$. Factors affecting the size of this species}

There have been a good many reports concerning the facts that the size of parasites is considerably influenced by the host species, size, age and other factors. It has been also reported that the various factors of hosts may influence the reproductive capacity, behavior, longevity and morphological aspects etc. of adult parasites (Flanders 1935, Salt 1940, Ohgushi, 1959, Wylie 1963, 1964 etc.).

In this species which has a wide host range, it may be fully conceivable that the size of adult parasites is affected by the host species, size, age and other factors. As shown in Figs. 24, 25 and 26, this species collected from the field actually shows a wide range of body size. Some of the factors affecting the size of adult parasites were investigated.

\section{Relation between the size of host pupae and adult parasites.}

Investigation was conducted on the relation between the size of host 
pupae and adult parasites emerged.

The pupae of Galleria mellonella reared in a $25^{\circ} \mathrm{C}$ insectary and the same of Chilo suppressalis collected from their hibernacula were used as hosts. These pupae were not older than 2 days after pupation. The size of host pupa is expressed as the body length $x$ maximum body width and that of adult parasite emerged from the host pupa by the length of forewing for the sake of convenience.

As indicated in Figs. 20 and 21, the size of adult parasites is greatly affected by the species and the host size. The adult parasites show an increasing tendency in size as the host size of either the parasite of $\mathrm{C}$. suppressalis or G. mellonella becomes large. There may be observed a high positive correlation, $r=0.789$, between the size of host pupa of C. suppressalis and that of adult parasite, and, $r=0.779$, between the size of host pupa of G. mellonella and that of adult parasite.

The author gave the pupa of Parnara guttata $(25 \mathrm{~mm} \times 5 \mathrm{~mm}$ in length and maximum width) for oviposition of the parasite, and the male offspring emerged from the pupa had the forewing $8.5 \mathrm{~mm}$ in length. This length was by far the largest one experienced by the author during his experiments and field observations.

2. Effect of host age on the size and developmental period of the parasite.

As mentioned before (Page 22), this species oviposits irrespective of

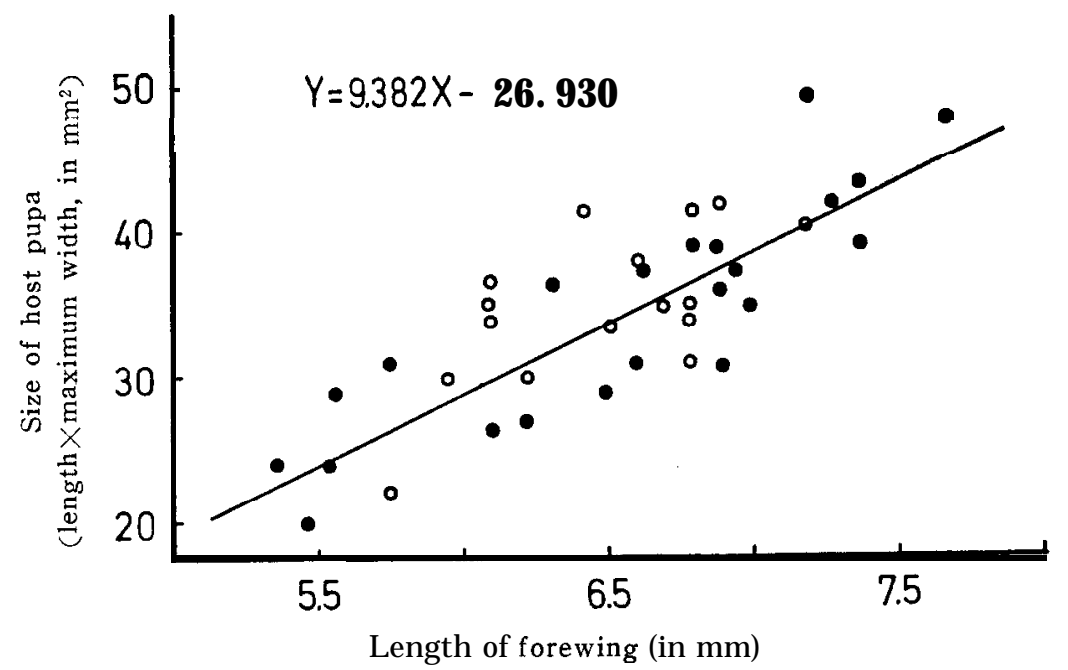

Fig. 20. Relation between the size of host pupa (Chilo suppress\& s) and that of adult parasite (Itoplectis narangae). Open circle : female, Solid circle: male, 


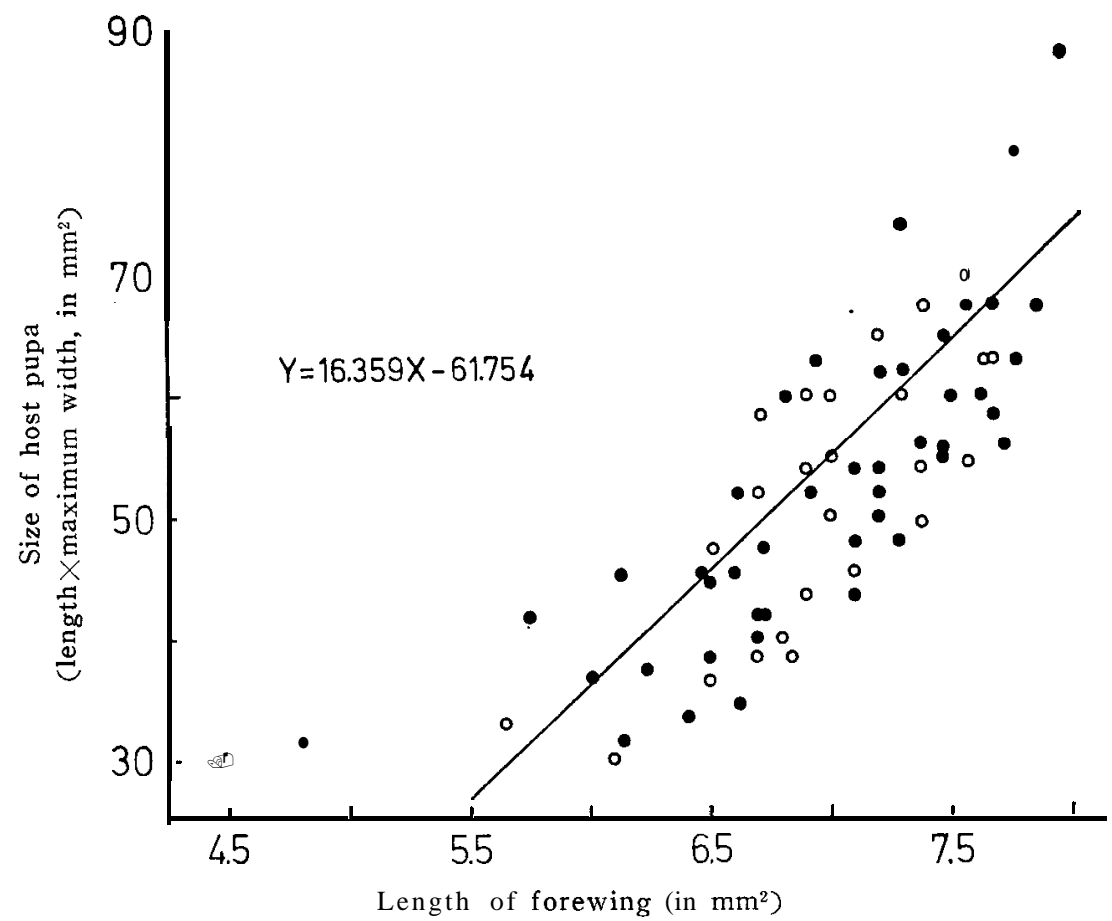

Fig. 21. Relation between the size of host pupa (Galleria mellonella) and that of adult parasite (Itoplectis narangae). Open circle: female, Solid circle: male.

host age. In this case it may be conceivable that various host age probably has some effects on the immature stage of this species growing within the host body. Wylie (1962, 1963 and 1964) studied in detail the effect of host age by using Nasonia vitripennis (Walker) (Hym., Pteromalidae). He made it clear that the size of parasites becomes small and the developmental period is prolonged as host age advances.

The author investigated by using the pupae of $\mathrm{G}$. mellonella how host age affects the size and developmental period of this species.

Methods : The adult parasites and alternate host pupae of G. mellonella used for the present experiment were reared in a $25^{\circ} \mathrm{C}$ insectary. To get the parasites of uniform size for experimental purposes the host pupae of 13.5-14.0 $\mathrm{mm}$ in length were exposed to the parasites. Next, in starting the experiment, the host pupae of $13.5-14.0 \mathrm{~mm}$ in length were again used and devided into 5 groups by host age: Group I 1-2 days old, Group II 3-4 days old, Group III 5-6 days old, Group IV 7-8 days old and Group V 9-10 days old and to each group the parasites were supplied, After the deposition of one egg into the host pupa, the pupa 
was confined to a small tube. The duration of developmental period of this species was recorded together with the measurement of the length of forewings. These experiments were conducted in a $25^{\circ} \mathrm{C}$ insectary and the results are indicated in Table 24 and Fig. 20.

As shown in Table 30 and Fig. 22, the size of this species became

Table 30. Length of forewing of Itoplectis narangae reared from Galleria mellonella pupae of different ages.

\begin{tabular}{|c|c|c|c|c|c|c|}
\hline Sex & $\begin{array}{c}\text { Host age } \\
\text { group }\end{array}$ & $\begin{array}{l}\text { No. of } \\
\text { specimens }\end{array}$ & $\begin{array}{l}\text { M e a } \mathrm{n} \\
\quad \text { (in }\end{array}$ & $\underset{\mathrm{mm})}{\operatorname{le~} \mathrm{g} g \mathrm{th}}$ & S.D. & $\begin{array}{c}\text { Confidence interv. } \\
(9596)\end{array}$ \\
\hline \multirow{5}{*}{ Male } & I & 20 & 7.18 & & 0.12 & $7.12-7.24$ \\
\hline & II & 20 & 7.12 & & 0.09 & $7.08-7.16$ \\
\hline & III & 20 & 6.93 & & 0.20 & $6.83-7.03$ \\
\hline & IV & 20 & 6.78 & & 0.28 & $6.65-6.91$ \\
\hline & V & 20 & 6.00 & & 0.78 & $5.64-6.36$ \\
\hline \multirow{5}{*}{ Female } & I & 20 & 7.19 & & 0.24 & $7.08-7.30$ \\
\hline & II & 20 & 7.07 & & 0.19 & $6.98-7.16$ \\
\hline & III & 20 & 6.95 & & 0.29 & $6.81-7.09$ \\
\hline & IV & 20 & 6.74 & & 0.27 & $6.62-6.86$ \\
\hline & V & 20 & 6.01 & & 0.78 & $5.64-6.38$ \\
\hline
\end{tabular}

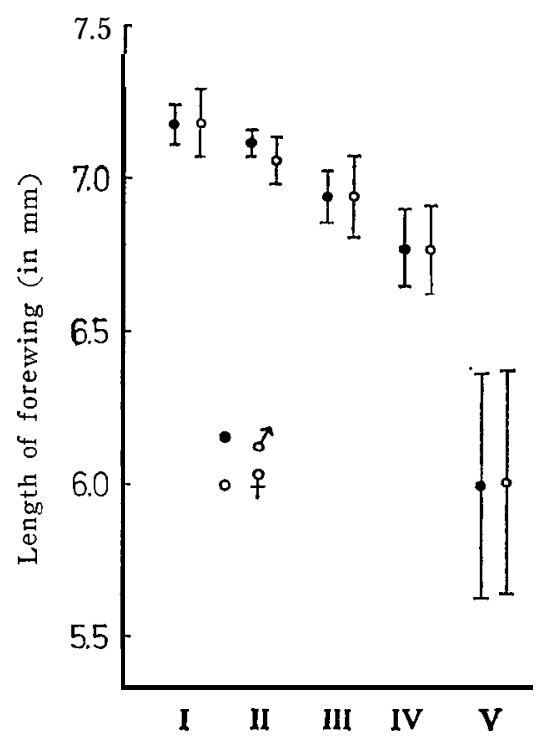

Host age group

Fig. 22. Average length of forewing of Ztoplectis narangae reared from Galleria mellonella pupae of different age groups, 
apparently smaller with the increase of host age, and no difference was observed in the size of the male and female of each host age groups.

No marked difference was observed between the Group II and the Group I, while the Groups III, IV and V became small significantly. Especially the Group V was markedly smaller than the other groups. The adult of the Group I and II emerges from the host pupa by making an exit hole on the head, while almost all of the parasites of the Group $\mathrm{V}$ emerged from the host pupa by making an exit hole on the abdomen. The dissection of the host pupa of the Group V revealed that the contents of fluid-like substances were only found in the abdomen in which the development of the imaginal internal tissues or organs were in progress.

Assuming these results, the size of this species seems to become smaller due to the decrease of sufficient nutrient with the increase of host age.

Table 31 and Fig. 23 show the period of the post development of both sexes of this species parasitized on the host pupae of the five age groups. The developmental period of this species is apparently prolonged as the host age advances, and the male emerges generally earlier than the female. In the Group $\mathrm{V}$ the period is prolonged about one day on an average compared with the Group I. There is no great difference in the developmental period of the Groups I and II, while a prolonged tendency of the development may be observed in the Group III in comparison with that of the Group I. This tendency appears also in the size of this species which becomes small in the Group III in comparison with that of the Group I. This may suggest that the

Table 31. Developmental period of Itoplectis narangae reared from Galleria mellonella pupae of different ages.

\begin{tabular}{cccccc}
\hline Sex & $\begin{array}{c}\text { Host age } \\
\text { group }\end{array}$ & $\begin{array}{c}\text { No. of } \\
\text { specimens }\end{array}$ & $\begin{array}{c}\text { Mean period } \\
\text { (in days) }\end{array}$ & S. D . & $\begin{array}{c}\text { Confidence interv. } \\
\text { (95 96) }\end{array}$ \\
\hline \multirow{4}{*}{ Male } & I & 46 & $\mathbf{1 4 . 9}$ & $\mathbf{0 . ~ a 3}$ & $14.7-15.2$ \\
& II & 45 & 14.8 & 1.08 & $14.4-15.1$ \\
& III & 44 & 15.2 & 0.94 & $15.0-15.5$ \\
& IV & 28 & 15.9 & 0.88 & $15.6-16.2$ \\
Female & V & 23 & 16.0 & 1.31 & $15.4-16.6$ \\
& I & 23 & $\mathbf{1 5 . 0}$ & $\mathbf{1 . 1 3}$ & $\mathbf{1 4 . 5 - 1 5 . 5}$ \\
& III & 21 & 15.0 & 0.71 & $14.7-15.3$ \\
& IV & 29 & 15.7 & 0.96 & $15.3-16.1$ \\
& V & 20 & 16.5 & 0.67 & $16.1-16.8$ \\
\end{tabular}




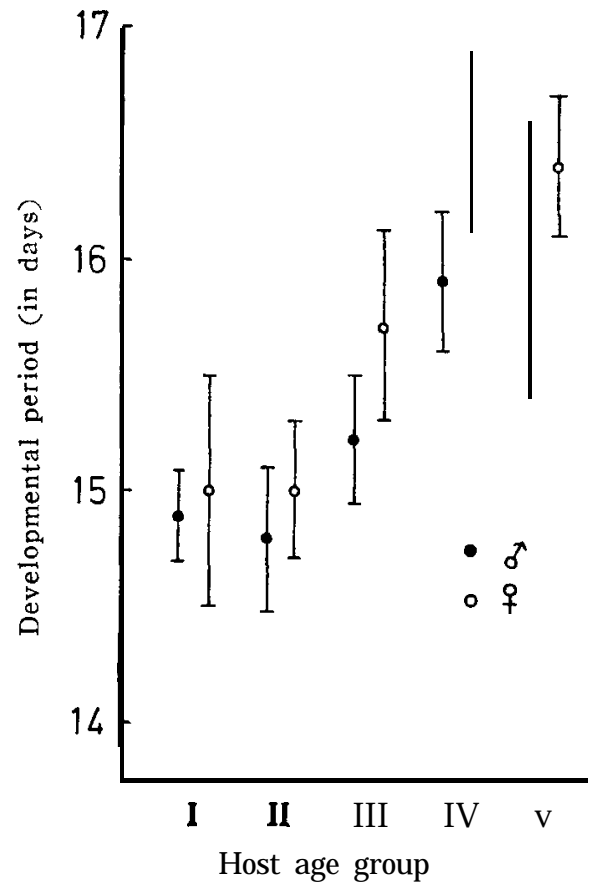

Fig. 23. Average developmental period of Ztoplectis narangae reared from Galleria mellonella pupae of different age groups.

difference in the content of host pupa has a remarkable effect on the developmental period of the larva of this species in the Group III. The effect of host age on the developmental period of the parasites which are produced by the difference of quality and quantity of food for parasite larva has been recorded by several workers (Salt 1938, Hafez 1961, Fisher 1961, etc.).

As described above, the effect of host age on the size and developmental period of this species is closely related to the selection of age of the Galleria mellonella pupa as an alternate host in the mass production of Itoplectis narangae. It has been already stated (Page 37) that the larger the size of this species the more eggs are laid. Therefore it is needless to say that the parasites having a large reproductive capacity are desired in making the mass production of Itoplectis narangae for the biological control purpose. 


\section{Morphological comparison between the specimens of Itoplectis narangae collected in the paddy field and those obtained from the materials emerged from Galleria mellonella pupa in the laboratory}

The investigation was conducted between the parasites which were reared successively from the alternate hosts in the laboratory and collected in the paddy field to observe the morphological differences if any.

Methods: Twenty-eight males and seventeen females of Ztoplectis narangae were collected for a period from the later part of September to that of November, 1967 in the paddy field at Hakozaki, Fukuoka City. Twenty one males and twenty seven females were emerged from the pupae of Galleria mellonella in the laboratory. The length of forewing, width of thorax, width of head and the length of ovipositor of the parasites were measured with the micrometer under a binocular microscope for the sake of comparison.

Results: In Figs. 24, 25 and 26 illustrate the relative growths of the width of head, width of thorax and the length of ovipositor between the individual parasites which were collected in the paddy field and reared in the laboratory. Generally, the size of the specimens collected

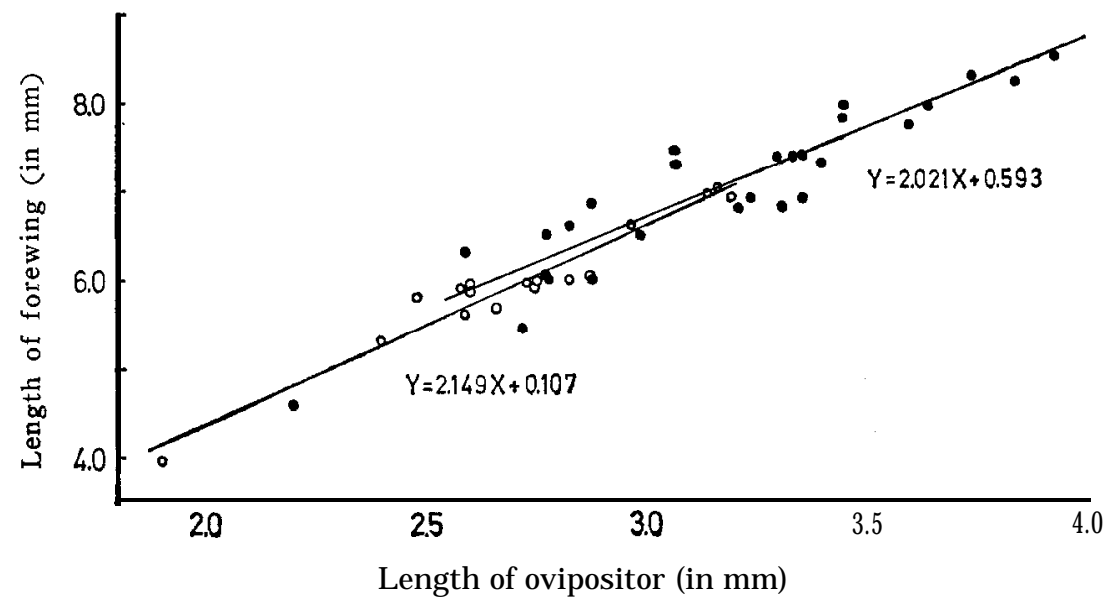

Fig. 24. Relation between the length of forewing and the length of ovipositor of Ztoplectis narangae which were collected in the paddy field in 1967 and reared from the pupae of G alleria mellonela in the laboratory.

$O$ : collected in the paddy field.

: emerged from the pupae of Galleria mellonela in the laboratory. 


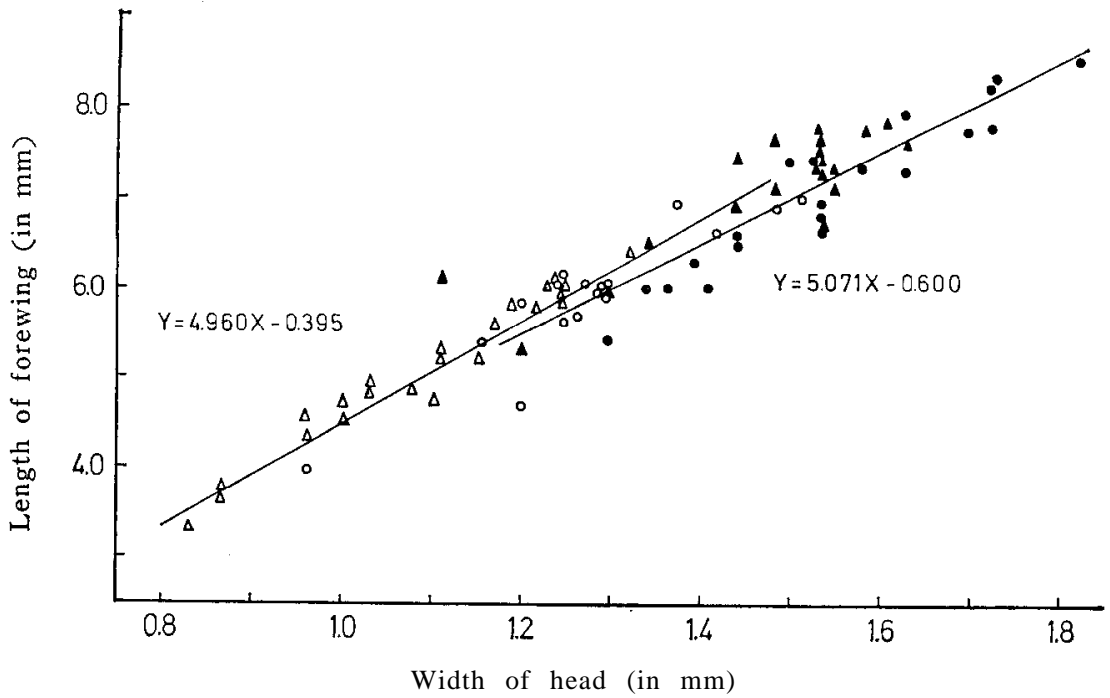

Fig. 25. Relation between the length of forewing and the width of head of Itoplectis narangae which were collected in the paddy field in 1967 and reared from the pupae of Galleria mellonella in the laboratory.

$\triangle$ male, $\bigcirc$ female: collected in the paddy field.

$\Delta$ male, female: emerged from the pupae of Galleria mellonella.

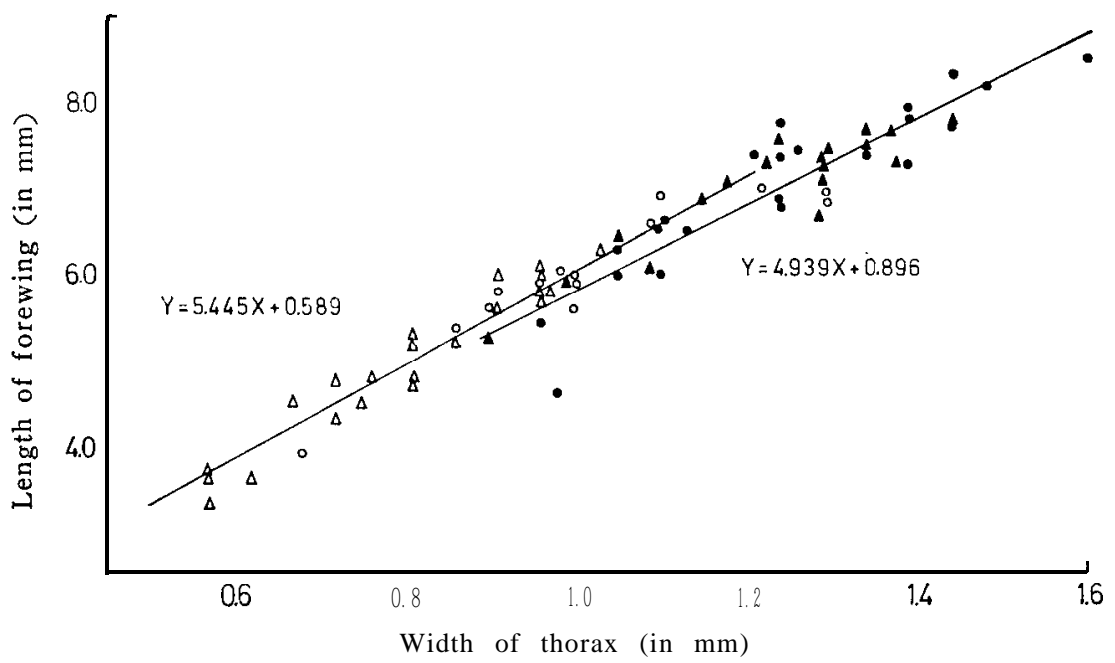

Fig. 26. Relation between the length of forewing and the width of thorax of Itoplectis narangae which were collected in the paddy field in 1967 and reared from the pupae of Galleria mellonella in the laboratory.

$\triangle$ male, $\bigcirc$ female: collected in the paddy field.

$\Delta$ male, $\mathbf{D}$ female: emerged from the pupae of Galleria mellonella. 
in the paddy field was apparently smaller than that of those reared in the laboratory, and the male was also somewhat smaller than the female. The host of the specimens collected in the paddy field was unknown. However, at that time there occurred an outbreak of Cnaphalocrocis medinalis, one of the hosts of Itoplectis narangae. Therefore, it is presumed that most of the parasites might have emerged probably from the pupae of $\mathrm{C}$. medinalis and that the smaller size of the pupae of $C$. medinalis caused the smaller size of the parasite collected in the paddy field as compared with those reared from the larger pupae of G. mellonella.

There was also observed no morphological difference except the relative growth affected by the size of parasites.

\section{Effect of some insecticides on the adult and immature stages of Itoplectis narangae}

It is a well known fact that some insecticides have detrimental effects on the parasite-predator populations. In recent years to eliminate an unfavorable condition produced by one-side application of insecticides without giving any consideration on the natural enemies an integrated control has been extensively discussed (Stern et al. 1959, van den Bosch and Stern 1962, Bartlett 1964, Beirne 1967, etc.).

On the effect of some insecticides on the adult parasite in the paddy field Tsutsui (1949) reported that DDT and BHC affect seriously Trichogramma japonicum Ashmead which is an egg parasite of Chilo suppressalis.

The author investigated the effect of some insecticides which have been used for the control of insect pests of the rice plant in the paddy field on this parasite at Hakozaki, Fukuoka City. The annual frequency of insecticidal appplications w-as 4 or 5 times, the first application in early July, the second one in early August, the third one in the middle of August, the fourth one in the later part of September, and the fifth one in the early October. Of course, the application frequency varied in accordance with the increase of insect pests, Although there were available many different kinds of insecticides from the makers, they were mainly the mixtures of $\gamma$-BHC, Sevin and Sumithion, and the dust was exclusively applied by using the duster, but the emulsion was not used at all.

Some experiments were performed with the above-mentioned three insecticides in a $25^{\circ} \mathrm{C}$ insectary. 


\section{Effect of insecticides on the adult Itoplectis narangae.}

This experiment was conducted with the use of insecticides of the ordinary concentration and of those diluted in various low concentrations. Parasites which were reared on honey for 3-4 days after emergence were used for the experiment in the laboratory.

For the methods of contact, filter paper dusted with insecticide was put in the test tube $(3 \times 20 \mathrm{~cm}$ in diameter and length) containing 20 adults so as to make them move over it for a certain time. And also a small amount of dust insecticide was put in the test tube containing 20 adults and the tube was shaked ligthtly to contact the adults with the insecticide. In the former case, observation was made continuously within the test tube after taking off the dusted filter paper and in the latter case, the adults were observed after removing them to a clean petri dish (16.2 x $3.2 \mathrm{~cm}$ in diameter and height).

Results : The results are presented in Table 32.

Table 32. Effect of various insecticidal dusts and some other inert materials against the adult Itoplectis narangae at $25^{\circ} \mathrm{C}$.

\begin{tabular}{|c|c|c|c|c|c|}
\hline Dust & $\begin{array}{l}\text { No. of } \\
\text { individuals } \\
\text { used }\end{array}$ & \multicolumn{4}{|c|}{ 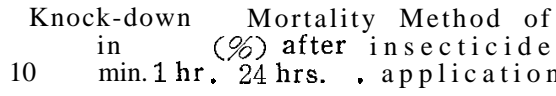 } \\
\hline$\left(\begin{array}{ll}3 \% \\
)\end{array}\right.$ & 20 & 100 & 100 & 100 & \multirow{3}{*}{ Dusting } \\
\hline$(1.5 \%)$ & 20 & 55 & 100 & 100 & \\
\hline Sumithion $(2.096)$ & 20 & 100 & 100 & 100 & \\
\hline$(3 \%)$ & 20 & 100 & 100 & 100 & \multirow{3}{*}{$\begin{array}{l}\text { Contact } \\
\text { with their } \\
\text { legs }\end{array}$} \\
\hline$(1.5 \%)$ & 20 & 0 & 100 & 100 & \\
\hline Sumithion $(2.0 \%)$ & 20 & 100 & 100 & 100 & \\
\hline Talc & 20 & 0 & 0 & 0 & \\
\hline Diatomaceous earth & 20 & 0 & 0 & 0 & Dusting \\
\hline
\end{tabular}

It may be seen that all the individuals were knocked down within 10 minutes by dusting $\gamma$-BHC and Sumithion, while more than half were knocked down by Sevin. In either case all individuals were killed within 24 hours. The results obtained by walking on the insecticides was not much different from that of the dusting method. Although no knocked down individuals were seen within 10 minutes by Sevin, all were cramped and knocked down within an hour after dusting. For comparative purpose, both talc and diatomaceous earth, the commonest diluents, were dusted. The result showed that the individuals tried to shake off such dusts hardly for a while at the beginning of dusting, but gradually they resumed their normal condition after an 
hour and continued normal survival. $\gamma$-BHC, Sevin and Sumithion of the ordinary concentration showed strong insecticidal action on the parasites which were dusted or walked on the dusted paper.

A similar experiment to that described above was performed with the insecticides of the low concentrations as shown in Tables 33, 34 and 35 .

As shown in Table 33, all individuals were killed within 24 hours by dusting 0.6 and $0.3 \% \mathrm{r}$-BHC. Although all of the individuals were cramped and knocked down within an hour by $0.2 \%$ dusting, $40 \%$ of them died and $60 \%$ resumed their normal condition after 24 hours. In case the parasites walked on the paper dusted with $0.6 \% \gamma$-BHC, $65 \%$ was cramped and knocked down within an hour.

The dusting of $0.4 \%$ and $0.2 \%$ Sumithion knocked down all individuals within an hour and caused death within 24 hours. Although no individuals were seen knocked down within an hour by the contact of dust with their legs, more than half died within 24 hours after showing the symptom of pain.

Table 33. Effect of the insecticidal dust of $\boldsymbol{r}$-BHC against the adult Itoplectis narangae at $25^{\circ} \mathrm{C}$.

\begin{tabular}{|c|c|c|c|c|c|c|c|}
\hline Dust & $\begin{array}{l}\text { Concen- } \\
\text { tration } \\
\qquad(96)\end{array}$ & $\begin{array}{c}\text { No. of } \\
\text { individuals } \\
\text { used }\end{array}$ & $\begin{array}{r}\text { Knock-c } \\
\text { in } \\
10 \text { min. }\end{array}$ & $\begin{array}{l}\text { lown } \\
1 \mathrm{hr} \text {. }\end{array}$ & $\begin{array}{l}\text { Mort } \\
24 \text { hrs. }\end{array}$ & $\begin{array}{l}\text { ality } \\
\text { after } \\
48 \text { hrs. }\end{array}$ & $\begin{array}{l}\text { Method of } \\
\text { insecticide } \\
\text { application }\end{array}$ \\
\hline \multirow{6}{*}{ r-BHC } & 0.6 & 20 & 100 & 100 & 100 & & \multirow{3}{*}{ Dusting } \\
\hline & 0.3 & 20 & 40 & 100 & 100 & & \\
\hline & 0.2 & 20 & 0 & 100 & 40 & 45 & \\
\hline & 0.6 & 20 & 10 & 65 & 10 & 10 & \multirow{3}{*}{$\begin{array}{l}\text { Contact } \\
\text { with their } \\
\text { legs }\end{array}$} \\
\hline & 0.3 & 20 & 0 & 35 & 10 & 10 & \\
\hline & 0.2 & 20 & 0 & 0 & 0 & 0 & \\
\hline
\end{tabular}

Table 34. Effect of the insecticidal dust of Sumithion against the adult Itoplectis narangae at $25^{\circ} \mathrm{C}$.

\begin{tabular}{|c|c|c|c|c|c|c|c|}
\hline Dust & $\begin{array}{l}\text { Concen- } \\
\text { tration } \\
(90)\end{array}$ & $\begin{array}{l}\text { No. of } \\
\text { individuals } \\
\text { used } \\
10\end{array}$ & $\begin{array}{r}\text { Knock-c } \\
\text { min }\end{array}$ & $\begin{array}{l}\text { lown } \\
1 \mathrm{hr} \text {. }\end{array}$ & $\begin{array}{l}\text { Mort } \\
\text { (\%) } \\
24 \text { hrs. }\end{array}$ & $\begin{array}{l}\text { ality } \\
\text { after } \\
48 \text { hrs. }\end{array}$ & $\begin{array}{l}\text { Method of } \\
\text { insecticide } \\
\text { applicatin }\end{array}$ \\
\hline \multirow{6}{*}{ Sumithion } & 0.4 & 20 & 0 & 100 & 100 & & \multirow{3}{*}{ Dusting } \\
\hline & 0.2 & 20 & 0 & 100 & 100 & & \\
\hline & $\begin{array}{r}0.13 \\
-\quad-\quad-\end{array}$ & 20 & 0 & 40 & 100 & & \\
\hline & 0.4 & 20 & 0 & 0 & 65 & 80 & \multirow{3}{*}{$\begin{array}{l}\text { Contact } \\
\text { with their } \\
\text { legs }\end{array}$} \\
\hline & 0.2 & 20 & 0 & 0 & 40 & 60 & \\
\hline & 0.13 & 20 & 0 & 0 & 0 & 15 & \\
\hline
\end{tabular}


Table 35. Effect of the insecticidal dust of Sevin against the adult Itoplectis narangae at $25^{\circ} \mathrm{C}$.

\begin{tabular}{llcccccc}
\hline Dust & $\begin{array}{c}\text { Concen- } \\
\text { tration } \\
(\%)\end{array}$ & $\begin{array}{c}\text { No. of } \\
\text { individuals } \\
\text { used }\end{array}$ & $\begin{array}{c}\text { Knock-down } \\
\text { in }\end{array}$ & $\begin{array}{c}\text { Mortality } \\
\text { (\%) }\end{array}$ & $\begin{array}{c}\text { Method of } \\
\text { after } \\
\text { insecticide } \\
\text { application }\end{array}$ \\
\hline \multirow{3}{*}{ Sevin } & 0.3 & 20 & 0 & 0 & 65 & 65 & \\
& 0.15 & 20 & 0 & 0 & 10 & 20 & Dusting \\
& 0.1 & 20 & 0 & 0 & 0 & 0 & \\
\cline { 2 - 7 } & 0.3 & 20 & 0 & 0 & 0 & 0 & Contact \\
& 0.15 & 20 & 0 & 0 & 0 & 0 & $\begin{array}{c}\text { hith their } \\
\text { legs }\end{array}$ \\
\hline
\end{tabular}

The insecticidal effect of Sevin was markedly weak as compared with that of the two dusts described above, i. e. $65 \%$ was killed within 24 hours by the dusting of $0.3 \%$ Sevin, but none of the individuals were cramped and knocked down within an hour either by dusting or contacting with their legs. In the latter case the individuals were seemed to be suffered to some extent but the contact effect was not fatal.

Thus, the insecticidal effects of the three insecticides described above on the adult Itoplectis narangae were stronger in the following order: $\gamma$-BHC, Sumithion and Sevin within the range of the ordinary and low concentrations. Especially $\gamma-\mathrm{BHC}$ and Sumithion act strongly. It may be presumed that if these insecticides are dusted over the paddy field and the dusts are attached to the leaves and stems of rice plants or the adults of Itoplectis narangae, their effects on this parasite must be great and may cause eventually the discontinuation of their activities for a while.

\section{Effect of some insecticides on the immature stages of Itoplectis narangae within the host body.}

Investigation was performed to observe how the $\gamma$-BHC, Sumithion and Sevin dusts of the ordinary concentration affect the immature stages of this species within the host body.

Methods: Twenty pupae of Galleria mellonella younger than 3 days old were pasted on a cardboard of $14.5 \mathrm{~cm}$ in diameter and exposed to 5 females of Itoplectis narangae by using the Container B. They were taken out of the container after oviposition for 2 hours and the parasitization was confirmed by checking the puncture holes. Subsequently they were kept in a clean petri dish. The $\gamma$-BHC, Sumithion and Sevin dusts of the ordinary concentrations were applied 4, 7 and 10 days after the 
parasitization and then the counts were made on the number of cmerged adult parasite and on the dead parasite larvae within the host bodies by dissection. This experiment was conducted in a $25^{\circ} \mathrm{C}$ insectary.

Results: The result of this experiment is as shown in Table 36 . The proportion of the number of emerged adults after insecticidal treatment against the pupae of Galleria mellonella was indicated in terms of percentage emergence.

Table 36. Effects of some insecticides on the immature stages of Itoplectis narangae.

\begin{tabular}{|c|c|c|c|c|c|c|}
\hline Dust & $\begin{array}{l}\text { No. of } \\
\text { host } \\
\text { pupa } \\
\text { para- } \\
\text { sitized }\end{array}$ & $\begin{array}{l}\text { Days be- } \\
\text { tween para- } \\
\text { sitization }\end{array}$ & $\begin{array}{l}\text { No. of } \\
\text { adults } \\
\text { emerged }\end{array}$ & $\begin{array}{l}\text { Percent- } \\
\text { age } \\
\text { emer- } \\
\text { gence }\end{array}$ & $\begin{array}{l}\text { No. of d } \\
\text { individua } \\
\text { became adult } \\
\text { but died } \\
\text { just before } \\
\text { emergence }\end{array}$ & $\begin{array}{l}\text { ead } \\
\text { als } \\
\text { diedin } \\
\text { larval } \\
\text { stages }\end{array}$ \\
\hline \multirow{3}{*}{ r-BHC } & 20 & 4 & 18 & 90 & & \\
\hline & 20 & 7 & 19 & 95 & & \\
\hline & 20 & 10 & 14 & 70 & 2 & 2 \\
\hline \multirow{3}{*}{ Sevin } & 20 & 4 & 16 & 80 & & 2 \\
\hline & 20 & 7 & 15 & 75 & 3 & 1 \\
\hline & 20 & 10 & 17 & 85 & & 1 \\
\hline \multirow{3}{*}{ Sumithion } & 20 & 4 & 15 & 75 & 1 & 2 \\
\hline & 20 & 7 & 16 & 80 & 2 & 1 \\
\hline & 20 & 10 & 12 & 60 & 1 & 4 \\
\hline Check & 20 & & 16 & 80 & 1 & 1 \\
\hline
\end{tabular}

It may be seen from Table 36 that there is no much difference in the percentage of emergence between the non-treated check plot and the treated one. It seems, therefore, that the three insecticides of the ordinary concentrations which have strong insecticidal action on the adult parasite do not affect the immature stages of Itoplectis narangae within the host body.

\section{Approach to the mass production}

It is possible to make mass production of Itoplectis narangae by using the pupae of G. mellonella as an alternate host. G. mellonella is widely used as an alternate host of the parasites and nematoda and for the insect pathological study. The technique of its mass rearing has been also developed remarkably.

Haydak (1936), Peterson (1953) and Dutky et al, (1962) have studied 
the mass rearing of $\mathrm{G}$. mellonella on artificial diets.

On the mass production of $I$. narangae by using the pupae of G. mellonella two methods may be employed according to the size of the mass production scale. To make a small scale mass production the modified sandwich method (hereafter referred as S. M.) described at the outset of this paper is convenient. The author could get the necessary amount of $I$. narangae for the laboratory experiments in the rearing room by using this method. However, the S. M. is not suitable for a large scale mass production owing to its troublesome procedure. The S. M. using gauze between the pupae and parasites for oviposition and the direct ovipoistion method without using anything between the pupae and parasites (hereafter referred as D.M.) are compared in the following lines:

1) The oviposition response of parasites against hosts is more rapid by the S. M. than that found by the D. M.

2) The handling of parasites is very simple in the S. M. as compared with the D.M.

3) The gauze is usually contaminated with the body fluid as a result of the host feeding by the parasites and should be renewed once every 3 or 4 days when the S. M. is used, but such a consideration is entirely unnecessary in the D.M.

4) In the S.M. the parasite must hold the gauze with its legs at the time of inserting her ovipositor. Therefore, this act often prevents the correct insertion of her ovipositor into the pupae and the parasite becomes tired rapidly. On the other hand, in the D. M. the parasite can hold directly the host to lay her eggs.

5) In the S. M. a small amount of the body fluid is absorbed by the gauze, thereby the host feeding by the parasite becomes difficult and the body fluid is wasted. However, in the D. M. the parasite can utilize the body fluid completely.

Thus, the D. M. is more superior to the S. M. in making a large scale mass production of the parasite. The author designed an parasitization unit for this purpose as illustrated in Figs. 27 and 28.

\section{Parasitization unit.}

This oviposition box is consisted of the upper, middle and lower sections. The size may be properly determined according to the schedule of mass production. The figure was designed to handle 300 host pupae at the same time.

1) Upper section: A $10 \mathrm{~W}$ fluorescent light is installed on the interior side. 
2) Middle section: The upper side is covered with a $3 \mathrm{~mm}$ thick transparent plate glass that can be removed, if necessary, and a sliding door of transparent glass is fitted on one side of the front wall. In addition to the sliding door a $34 \mathrm{~mm}$ diameter hole is opened and the hole can be closed by a plastic sliding plate. Of course this hole may serve to release the parasites into the middle section. A space is also made on the lower side of the section to allow the setting of a free transparent plastic plate.

3) Lower section: A nylon net is spread over the upper side to prevent the escape of the parasites and a door that can be opened forward is fitted in the front. A $10 \mathrm{~W}$ fluorescent light is also installed on the interior base.

The three sections can be separable freely, and the size of the box is $30.5 \mathrm{~cm}$ in length, $58 \mathrm{~cm}$ in breadth and $44 \mathrm{~cm}$ in height.

\section{Direction for handling the parasitization unit.}

After switching- on the fluorescent light of the upper section, the mated adults are released in the box through a hole of the middle

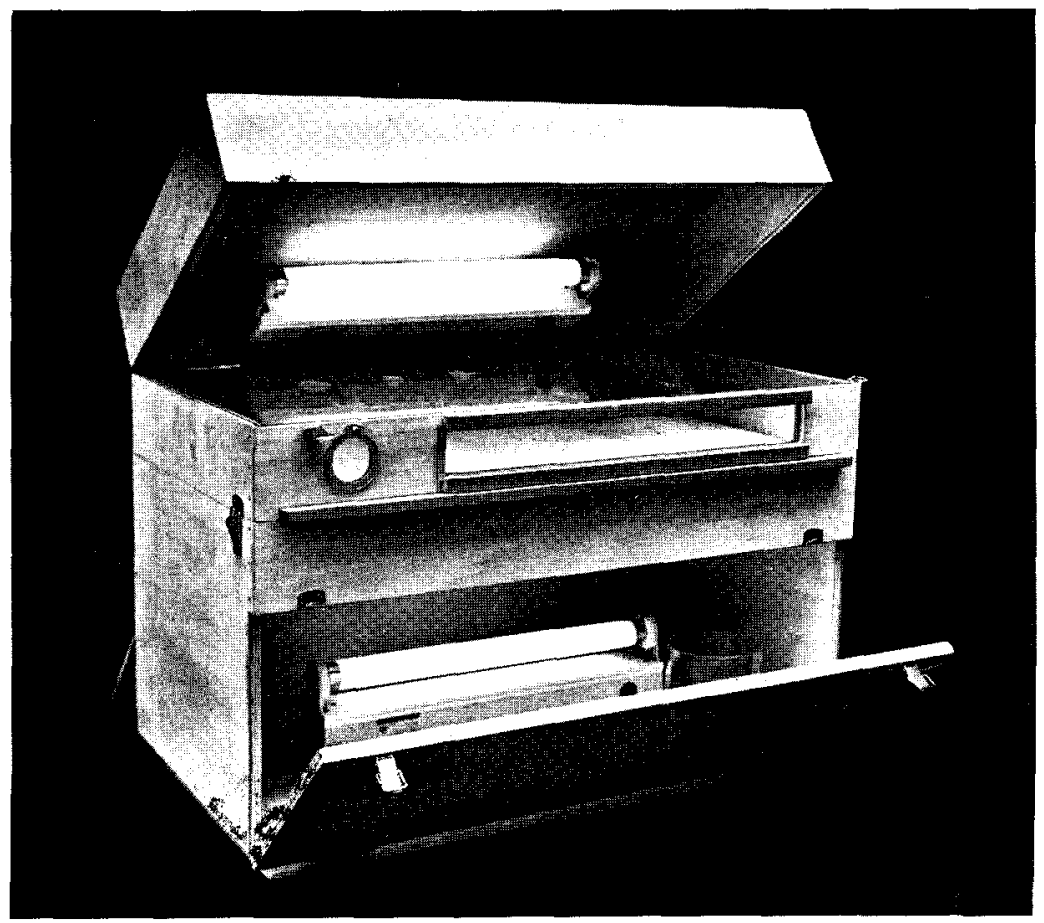

Fig. 27. Parasitization unit (designed by the author).' 


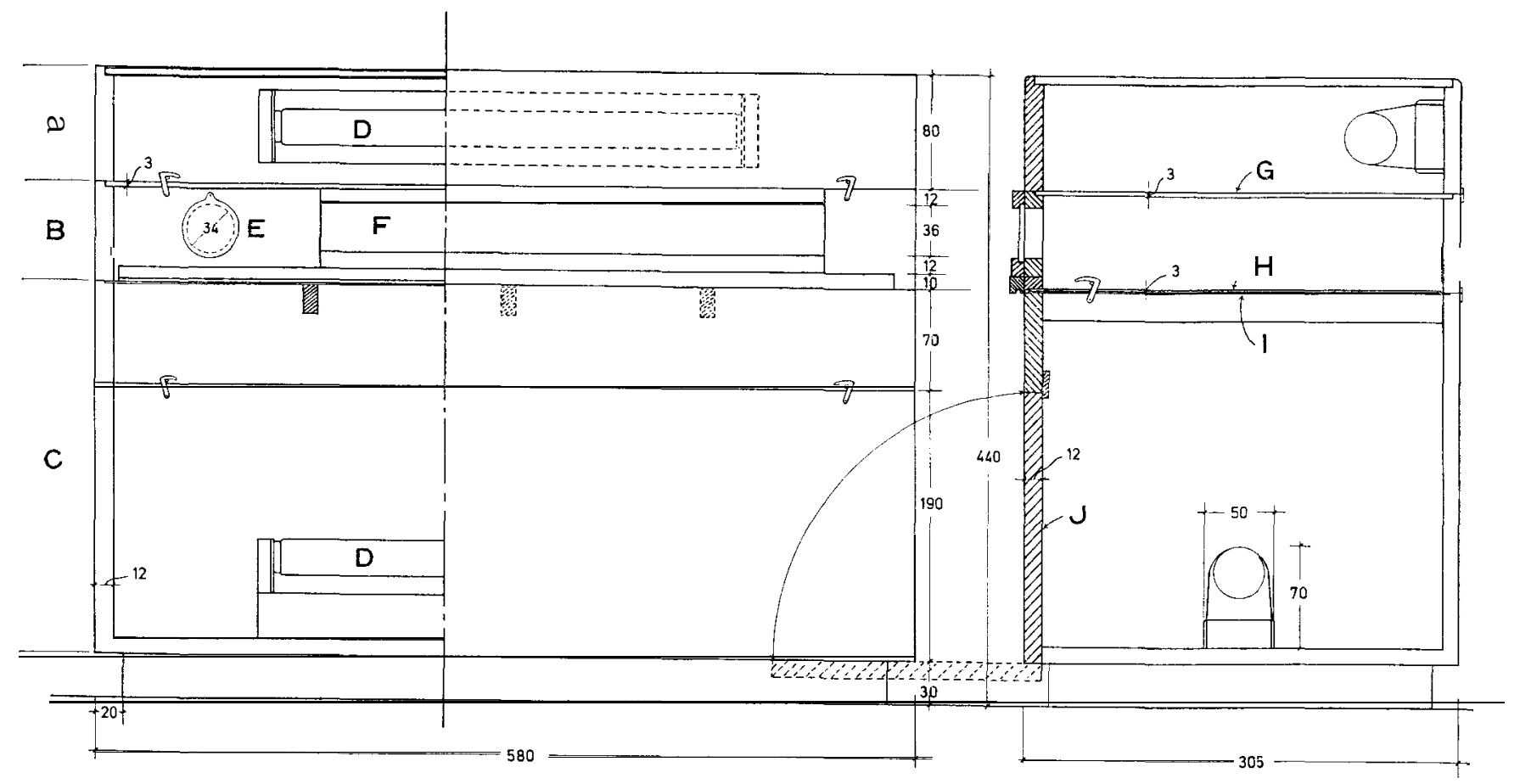

Fig. 28. Parasitization unit. A: Upper section, B: Middle section, C: Lower section, D: Fluorescent light, E: Hole, F : Sliding door, G: Transparent plate glass, H: Transparent plastic plate, I: Nylon net, $\mathrm{J}$ : Door. The figure indicates the scale in milimeter. 
section and then the hole is closed up with a plastic cover so as to prevent the escape of the adult parasites. The adults are forced to come in touch with the glass surface of the middle section by the positive phototaxis. Prior to the introduction of parasites into the middle section undiluted honey and absorbent cotton soaked in a small amount of water are put on the glass plate of the middle section. Corrugated cardboard is cut in the same size as the plastic plate which is to be placed between the middle section and the lower section to separate both sections. The pupae of G. mellonella are placed on each groove of corrugated cardboard and this cardboard is put on the plastic plate. Next, the plastic plate with corrugated cardboard is inserted between the middle section and the lower section and switch off the fluorescent light of the upper section and then switch on the same of the lower section. The constant humidity in the box is maintained by placing a cylindrical petri dish containing water on the base of the lower section.

As described before, the adult $I$. narangae is poor in the discrimination of the parasitized or unparasitized hosts. Therefore, it is desirable to increase the number of parasites and shorten the exposure time in order to minimize superparasitism and enhance the percentage parasitism.

According to the preliminary experiments the percentage parasitism was $86.5 \%$ with $74 \%$ superparasitism when 20 hosts were exposed to 3 adult females of $I$. narangae for 3 hours. The results of rearing experiment with this oviposition box are presented in Tables 37 an 38 .

As shown in Tables 37 and 38, the percentage parasitism is the highest when 100-200 host pupae of G. mellonella are exposed to 20 parasites. This percentage parasitism is lower than the actual percentage in the parasitization unit, because those which died within the host body at the immature stage were not counted in this percentage. In all experiments the number of males was about 3 times as many as that of females.

Table 37. Results of exposing 100,200 and 300 host pupae of Galleria mellonella to 20 females of Itoplectis narangae for 5 hours.

\begin{tabular}{|c|c|c|c|c|c|c|c|}
\hline $\begin{array}{l}\text { No. of host } \\
\text { pupae } \\
\text { exposed }\end{array}$ & $\begin{array}{l}\text { No. of } \\
\text { parasites } \\
\text { released }\end{array}$ & Time of & $\begin{array}{l}\text { No. of } \\
\text { arasites } \\
\text { emerged }\end{array}$ & $\begin{array}{l}\text { Se } \\
\text { par } \\
\text { eme } \\
\sigma^{*}\end{array}$ & $\begin{array}{l}\text { of } \\
\text { ites } \\
\text { ged } \\
\text { o }\end{array}$ & $\begin{array}{l}\text { Sex } \\
\text { ratio } \\
(9 \%)\end{array}$ & $\begin{array}{c}\text { Percent- } \\
\text { age* } \\
\text { parasi- } \\
\text { tism }\end{array}$ \\
\hline 100 & 20 & $5 \mathrm{hrs}$. & 76 & 76 & 27 & 36 & 76 \\
\hline 200 & 20 & $5 \prime \prime$ & 146 & 103 & 43 & 30 & 74 \\
\hline 300 & 20 & 5 & 168 & 121 & 47 & 28 & 56 \\
\hline
\end{tabular}

* The ratio of the number of parasites emerged to the number of hosts exposed. 
Table 38. Results of exposing 100, 200 and 300 host pupae of Galleria mellonella to 10 females of Itoplectis narangae for 5 hours.

\begin{tabular}{|c|c|c|c|c|c|c|c|}
\hline $\begin{array}{c}\text { No. of host } \\
\text { pupae } \\
\text { exposed }\end{array}$ & $\begin{array}{l}\text { No. of } \\
\text { parasites } \\
\text { released }\end{array}$ & $\begin{array}{l}\text { Time of } \\
\text { exposure }\end{array}$ & $\begin{array}{c}\text { No. of } \\
\text { parasites } \\
\text { emerged }\end{array}$ & $\begin{array}{l}\text { Sex } \\
\text { para } \\
\text { eme } \\
\text { त }\end{array}$ & $\begin{array}{l}\text { of } \\
\text { tes } \\
\text { ged } \\
\text { 오 }\end{array}$ & $\begin{array}{c}\text { Sex } \\
\text { ratio } \\
(9 \%)\end{array}$ & $\begin{array}{l}\text { Percent- } \\
\text { age } \\
\text { parasit- } \\
\text { ism }\end{array}$ \\
\hline 100 & 10 & 5 hrs. & 66 & 41 & 15 & 23 & 66 \\
\hline 200 & 10 & $5 \%$ & 131 & 93 & 38 & 29 & 66 \\
\hline 300 & 10 & "1 & 100 & 78 & 22 & 22 & 33 \\
\hline
\end{tabular}

* The ratio of the number of parasites emerged to the number of hosts exposed.

The host feeding is the most important factor for the maintenance of reproductive capacity of the adult female and must be considered for the mass production. A large and younger alternate host is most favorable. As the parasite used for oviposition declines gradually in its reproductive capacity 2 or 3 weeks after oviposition started, it is desired to renew it with newly emerged parasite. After oviposition the fluorescent light of the lower section should be switched off and in turn the same of the upper section should be switched on. The plastic plate was then removed after the adult parasites left the host. When the host oviposited is removed to the insectary of $25^{\circ} \mathrm{C}$ temperature and relative humidity $50-70$ percent, the parasite emerges in 14 to 16 days.

\section{Conclusion \\ - Itoplectis narangae as a natural enemy \\ of major insect pests of rice plant -}

It is intended to discuss in this chapter on the usefulness of this species from the practical point of view based on the results obtained from the field and laboratory experiments, although there still remain many problems left unsolved.

1. The average reproductive capacity of this species is about 300 eggs per female. It is also a synovigenic species which can lay eggs for a prolonged period and maintains its reproductive capacity even during the absence of hosts. The oviposition of $I$. narangae is not affected by the size and age in days of the hosts.

2. It develops rapidly and emerges in 14 to 16 days under $25^{\circ} \mathrm{C}$ constant temperature condition. This fact suggests that the possibility of parasitism and the multiplication capacity may be enhanced on the presence of such hosts as Naranga aenescens and Cnaphalocrocis medinalis which have 4 to 5 generations a year. 
3. Not a single parasite against $I$. narangae has been observed during the field investigations except only those which were caught in the spider's web. Therefore, in the case of this species it is not necessary to consider its parasite.

4. The emergence of this parasite almost coincides with the appearance of hosts from the middle of May to early December, and attacks the hosts not only during the growth stage of rice plants but also before the hibernation of major rice pests after harvest so long as it survives.

5. The attacking activity of $I$. narangae continues vigorously during day time and its searching flight for the hosts is seen even in the hidden places. Once the host is found, it never flies away from the host until it lays eggs to the host successfully.

6. It seems to be unable to discriminate the parasitized or unparasitized hosts. Therefore, the phenomenon of superparasitism may be expected. As indicated by Iyatomi (1943), the superparasitism influences not only the decline of the percentage of parasitism but those of the increasing ratio of the number of parasites. But such superparasitism as observed in the narrow space of the laboratory experiment may not be observed in the field. Of course, in the case of high parasite density, the superparasitism will possibly appear.

7. This species is widely distributed throughout the vast rice growing areas of Asia ranging from the Kuriles in the north to the Philippines in the south. This may suggest that $I$. narangae is most adaptable to a wide range of climatic conditions.

8. The mass production is possible by using the pupae of $\mathrm{G}$. mellonella as an alternate host.

As discussed above, $I$. narangae is a vigorous parasite both in its attacking and reproductive ability. It may be recognized that this species is privileged with favorable natures as an excellent parasite. If this species is used for the control of one or small number of species of specific insect pests in the paddy field, no favorable results may be expected because its host range is too wide. However, it seems impossible to neglect the effectiveness of this species in the case of major insect pests, in controlling the pests in question to some extent. On the other hand, there are many difficult problems involved in the possibility of its utilization for the enhancement of the practical control effect by facilitating the activities of this species.

1. The microclimate in the close planting paddy field for multiyields restricts the searching zone of $I$. narangae. Accordingly, those insect pests which are living out of this searching zone can be free from the attack of parasites, There will arise eventually a problem 
how to remove the barrier of its activities in order to keep the insect pests to be attacked within the searching zone of the parasites. This problem has a close connection with the cultural method and yields of rice crops.

2. At present and even in the future, no rice culture can be considered without insecticidal applications. In recent years, insecticidal application has been widely introduced, especially a motorized dusting equipment and the use of helicopter or airplane have made it possible to dust insecticides over a vast area at the same time and in a short period. In any case, if we use the strong contact insecticides, such insecticides may restrict the activities of the parasite, decrease the number of parasite and create a buffer zone of I.narangae. But, it is a good tendency that recently the use of contact insecticides like chlorinated hydrocarbon or organophosphorus insecticides against the rice stem borers has been decreasing in the paddy field. The development of systemic use or soil application of granules of insecticides may overcome the difficulty of protecting the natural enemies of rice stem borers. Therefore, it is one of the most important problems how to apply the insecticides reasonably and how to use natural enemies as the controlling agents of insect pests. In another word, how to conserve the natural enemies is one of the most important problems to be considered at the moment and also in the future.

\section{Summary}

The present work was carried out in the field and laboratory for two years in order to clarify the bionomics and the mass production method of Itoplectis narangae for the future use as a controlling agent against the major rice pests. The results are summarized as follows:

1. This species develops 4 or 5 times a year from the middle of May to early December and hibernates as the final instar larval stage within the host body. It seems that the searching zone in the paddy field is closely correlated to the microclimate and that the lower part of rice plant is not searched by this species.

2. The larval stage ends at the fifth instar and each instar can be discriminated by the width of head capsule. The developmental period varies according to the rearing temperature and host species. The average developmental period on the host pupa of Galleria mellonella under the constant temperature condition of $25^{\circ} \mathrm{C}$ is 14.0 days in male and 14.9 days in female. The body color also varies according to the rearing temperature and black color does not develop as temperature rises, 
3. The host feeding was observed during the oviposition period. It was observed that this species sucked water on the leaf of rice plant in the field and visited flowers in the carrot field to get nutrient from them. It was also observed that the species was taking honeydew excreted by the aphids on the ear of rice plant.

4. The male emerges earlier than the female. The female mates soon after emergence.

5. It seems that the oviposition is not affected by the age in days, dorsal and ventral sites and sizes of the host.

6. This species is unable to discriminate the parasitized or unparasitized host. There was no case in which more than one parasite emerged from the superparasitized host.

7. Arrhenotokous parthenogenesis is seen in this species.

8. Mature eggs in the ovaries are produced from the first day after emergence irrespective of feeding. It reaches the peak in the second day when unfed and in the third day if fed with diets. Thereafter, the o\&sorption proceeds gradually and the number of matured eggs decreases.

9. This parasite is a synovigenic species. The preoviposition period is 1 to 2 days on an average. There is no difference in its reproductive capacity between the mated and unmated females. A female lays 300 eggs on an average, but the number of eggs deposited varies greatly according to the individuals. High pcsitive correlation was observed between the fecundity and the size of this parasite. The daily fluctuation of oviposition shows the continuation of increase and decrease and vice versa.

10. The number of eggs deposited increases rapidly until the sixth day after the start of oviposition and active oviposition takes place for the first 14 to 21 days and decreases gradually thereafter. More than $70 \%$ of the total number of eggs deposited is laid for 20 days after the start of oviposition.

11. The number of ovarioles observed is ranging from 11 to 28 and about $25 \%$ of which are formed symmetrically. It seems that the size of this species is not correlated to the number of ovarioles.

12. The longevity is shortened as temperature rises. Water is somewhat helpful to extend the longevity of this species. The parasite fed with water survived longer than that fed with honey under high temperatures. The unfed parasite survived for about 5.7-5.8 days on an average under the constant temperature condition of $25^{\circ} \mathrm{C}$ while those fed with undiluted honey and water survived for 36.1 days in male and 46.8 days in female respectively.

13. When the parasite was given hosts after being withheld from 
hosts for 10, 15 and 20 days, oviposition behavior proceeded immediately. The o\&sorption of matured eggs in the ovaries took place during the period of lacking host. However, matured eggs remained in the ovaries and the reproductive capacity was still maintained even after the elapse of days indicated above.

14. The size and age in days of the host pupa affected the size of this species, and the developmental period was somewhat prolonged as the age in days advanced.

15. There was observed no morphological difference between this species reared on Galleria mellonela in the laboratory and those collected in the field, expect the relative growth affected by the size of host and other factors.

16. The insecticidal action of $\gamma$-BHC, Sevin and Sumithion of the ordinary concentration on the adults of this species was remarkable while the immature stage within the host pupa was not affected at all. The insecticidal action of these three insecticides was strong in the order of $\gamma$-BHC, Sumithion and Sevin. The survival of this species was not affected by talc and diatomaceous earth used as diluents.

17. The mass production is possible by using the pupae of $\mathrm{G}$. mellonella. The parasitization unit was designed to facilitate the handling of parasites for the mass production.

\section{Acknowledgements}

The author wishes to express his deepest appreciation to Prof. K. Yasumatsu, Kyushu University under whose direction this work was done. The author is also much obliged to him for his constant advice, encouragement and the facilities of his department, as well as for the kind help in the preparation of the manuscript.

My cordial thanks are due to Assoc. Prof. Y. Hirashima and Dr. K. Yano, Kyushu University for their kindness in many ways during the course of this study.

The author desires to express his hearty gratitude to Prof. T. Torii, Assoc. Prof. Y. Murakami, Dr. Y. Hirose and Dr. H. Kajita of the Institute of Biological Control, Kyushu University for their helpful suggestion and information about the literature.

The author is also indebted to other members of the Entomological Laboratory, Kyushu University and the Institute of Biological Control, Kyushu University for their kind help and cooperation throughout this work, 


\section{References}

Arthur, A. P. and Wylie, H. G. 1959. Effects of host size on sex ratio, development time and size of Pimpla turionellae (L.) (Hymenoptera, Ichneumonidae). Entomophaga 4: 297-307.

Arthur, A. P. 1962. Influence of host tree on abundance of Itoplectis conquisitor (Say) (Hymenoptera, Ichneumonidae), a polyphagous parasite of the European pine shoot moth, Rhyacionia buoliana (Schiff.) (Lepidoptera, Olethreutidae). Can. Ent. 94: 337-347.

Arthur, A.P. 1963. Life histories and immature stage of four Ichneumonid parasites of the European pine shoot moth, Rhyacionia buoliana (Schiff.) in Ontario. Can. Ent. 97: 1078-1091.

Ashmead, W. H. 1906. Descriptions of new Hymenoptera from Japan. Proc. U. S. Nat. Mus. 30: 180 .

Barras, R. 1960. The effect of age on the performance of an innate behaviour pattern in Mormoniella vitripennis (Walk.) (Hymenoptera, Pteromalidae). Behaviour 15: 210-218.

Bartlett, B. R. 1964. Integration of chemical and biological control. In DeBach (ed.), Biological control of insect pests and weeds, pp. 489-511, Chapman and Halls, London.

Beirne, B. P. 1966. The future of integrated controls. Mushi 39, Suppl.: 127-130.

Bess, H. A. 1967. Feasibility and problems of chemical control and biological control of rice stem borers (research on the natural enemies of rice stem borers). Mushi 39, Suppl.: 45-50.

Chéng, T. S. 1935. Biology of Naranga aenescens Moore in Kiangsu (Lep., Noctuidae). II. Ent. \& Phytopath. 3: 26.

Clausen, C. P. 1936. Insect parasitism and biological control. Ann. Ent. Soc. Amer. $29: 201-223$.

Clausen, C. P. 1939. The effect of host size upon the sex ratio of Hymenopterous parasites and its relation to methods of rearing and colonization. Jour. N.Y. Ent. Soc. 47: 1-9.

Cushman, R. A. 1922. New Oriental and Australian Ichneumonidae. Philip. Jour. Sci. 20: 543-595.

Cushman, R. A. 1922. New species of Ichneumon-flies with taxonomic notes. Proc. U. S. Nat. Mus. 60 (20): 9.

DeBach, P. 1943. The importance of host-feeding by adult parasites in the reduction of host populations. J. Econ. Entomol. 36: 647-658.

Doutt, R. L. 1959. The biology of parasitic Hymenoptera. Ann. Rev. Ent. 4: 161182.

Dutky, S. R. et al. 1962. A technique for mass rearing the greater wax moth (Lep., Galleridae). Proc. Ent. Soc. Wash. 64: 56-58.

Edwards, R. L. 1954. The effect of diet on egg maturation and resorption in Mormoniella vitripennis (Hym., Pteromalidae). Quart. J. Micr. Sci. 95: 459-468.

Emden, H. F. van. 1968. Observations on the effect of flowers on the activity of parasitic Hymenoptera. Ent. Mon. Mag. 98: 265-270.

Finlayson, T. 1960. Taxonomy of cocoons and puparia, and their contents, of Canadian parasites of Diprion hercyniar (Htg.) (Hym., Diprionidae). Can. Ent. 92 : $922-941$. 
Finlayson, T. 1960. Taxonomy of cocoons and puparia, and their contents, of Canadian parasites of Neodiprion sertifer (G eoff.) (Hym., Diprionidae). Can. Ent. 92: 20-47.

Fisher, R. C. 1961. A study in insect multiparasitism. II. The mechanism and control of competition for possession of the host. Jour. Exp. Biol. 38: 605-628.

Flanders, S. E. 1935. Host influence on the prolificacy and size of Trichogramma. Pan-Pacif. Ent. 11 (4): 175-177.

Flanders, S. E. 1942. O\&sorption and ovulation in relation to oviposition in the parasitic Hymenoptera. Ann. Ent. Soc. Amer. 35: 251-266.

Flanders, S. E. 1942. Metaphycushelvolus, an Encyrtid parasite of the black scale. J. Econ. Entomol. 35: 690-698.

Flanders, S. E. 1950. Regulation of ovulation and egg disposal in the parasitic Hymenoptera. Can. Ent. 82: 134-140.

Fukaya, M. 1938. [The effect of temperature-humidity conditions upon the fecundity of Trichogramma japonicum]. Ōyō-Dōbutsugaku Zasshi 10 (2) : 41-52. (in Japanese).

Györfi, T. 1951. Die Schlupfwespen und der Unterwuchs des Waldes. Z. ang. Ent. 33: $32-47$.

Hafez, M. 1961. Seasonal fluctuations of population density of the cabbage aphid, Brevicoryne brassicae (L.), in the Netherlands, and the role of its parasite, Aphidius (Diaeretiella) rapae (Curtis). Tijdschr. PlZiekt. 67: 445-548.

Hasegawa, J. et al. 1967. [The outbreak of Cnaphalocrocis medinalis Guénée in 1967]. Plant. Prot., Tokyo 21 (12):505-508. (in Japanese).

Haydak, M. H. 1936. A food for rearing laboratory insects. J. Econ. Entomol. 29: 1026.

Hidaka, T. 3965. Studies on the natural enemies of insects injurious to rice plant in Tohoku district in Japan. 1) On the parasites and predators attacking the rice stem borer and their ecological peculiarities. Rept. Tohoku Agr. Exp. Sta. 32: 145-160. (in Japanese with English summary).

Hirose, Y. 1966. Parasitic Hymenoptera visiting the flowers of carrot planted in the truck crop field. Sci. Bul. Fac. Agr. Kyushu Univ. 22 (3): 217-223. (in Japanese with English summary).

Holdaway, F. G. and Smith, H. F. 1932. A relation between size of host puparia and sex ratio of Alysia manducator Panzer, Austr. J. Exp. Biol. Med. Sci. 10: 247-259.

Ishii, T. 1933. [On the ecology of Trichogramma japonicum, an egg-parasite of the rice stem borer (Prelim. Rep.)]. Ōyō-Dōbutsugaku Zasshi 5 : 131-132. (in Japanese).

Ishii, T. 1934. [On the ecology of Trichogramma japonicum, an egg-parasite of the rice stem borer]. Ōyō-Dôbutsugaku Zasshi $6: 146-147$. (in Japanese).

Iwata, K. 1960. The comparative anatomy of the ovary in Hymenoptera. Part V. Ichneumonidae. Acta Hymenopterologica 1: 142.

Iyatomi, K. 1949. Study on the influences of new synthetic organic insecticides to

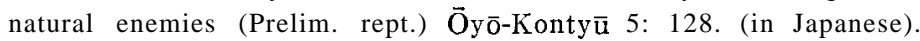

Iyatomi, K. 1950. The effect of hyperparasitism upon the reproduction of Trichogramma japonicum. Ōyō-Dōbutsugaku Zasshi 16 : 17-27. (in Japanese with English summary).

Johnston, F. A. 1913. On the feeding habits of Pimpla(Itoplectis) conquisitor Say. 
J. Econ. Entomol. 6: 144-147.

Juillet, J. A. 1959. Morphology of immature stages, life history, and behaviour of three Hymenopterous parasites of the European pine shoot moth, Rhyacionia buoliana (Schiff.) (Lep., Olethreutidae). Can. Ent. 91: 709-719.

Kamiya, K. 1941. The natural enemies of Adoxophyes privatana Walker. Konty 14: 224-226. (in Japanese).

Kim, C. W. 1963. Catalogue of Hymenoptera from Korea. The humanities and sciences, natural science, Tenth Anniversary, Korea Univ. 6: 303.

Kuwayama, S. 1928. [The principal insect-pests of the rice-plant in Hokkaido]. Bull. Hokkaido Agr. Exp. Sta. 47: 54-69. (in Japanese).

Kuwayama, S. 1932. [Studies on Lema oryzae Kuwayama, the rice leaf-beetle. Part III. Insect enemies of the rice leaf-beetle]. Rep. Hokkaido Agr. Expt. Sta. 29: 97-130. (in Japanese).

Leius, K. 1960. Attractiveness of different foods and flowers to the adults of some Hymenopterous parasites. Can. Ent. 92 : 369-376.

Leius, K. 1961. Influence of food on fecundity of longevity of adults of Ztoplzctis conquisitor (Say) (Hym., Ichneumonidae). Can. Ent. 93: 771-780.

Leius, K. 1961. Influence of various foods on fecundity and longevity of adults of Scambus buolianae (Htg.) (Hym., Ichneumonidae). Can. Ent. 93: 1079-1084.

Leius, K. 1963. Effects of pollens on fecundity and longevity of adult Scambus buolianae (Htg.) (Hym., Ichneumonidae). Can. Ent. 95: 202-207.

Loughton, B.G. 1965. The effect of parasitization by Pimplaturionellae (L.) on the emergence from the pupal case of its host, Galleriamellonella (L.). Can. Ent. 97: 314-316.

Matsuzawa, H. 1958. Ecological studies on the Braconid wasp, Apanteles glomeratus. Mem. Fac. Agr. Kagawa Univ. 3: 1-125. (in Japanese with English summary).

Minamikawa, J. 1943. Notes on the parasitic Hymenoptera of Naranga uenescens Moore (Lep., Noctuidae). Trans. Nat. Hist. Soc. Formosa 33: 221-229. (in Japanese).

Minamikawa, J. 1954. On the Hymenopterous parasites of the tea-leafrollers found in Japan and Formosa. Mushi 26: 36.

Minamikawa, J. 1954. On the Hymenopterous parasites of $\mathbf{N}$ arungu uenescens Moore

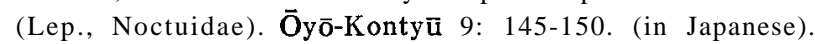

Momoi, S. 1968. A key to Ichneumonid parasites of rice stem borers in Asia. Mushi 41: 175-184.

Murakami, Y. 1966. Studies on the natural enemies of the comstock mealybug. II. Comparative biology on two species of internal parasites, Clausenia purpurea and Pseuduphycus malinus (Hym., Encyrtidae). Bull. Hort. Res. Sta., Ser. A 5: 139-163. (in Japanese with English summary).

Murata, T. et al. 1967. Report on the infestation of the grass leaf roller, Cnaphulocrocis medinalis Guénée. Res. Rep. Fukuoka Agr. Exp. Sta. 6: 25-32. (in Japanese).

Nawa, U. 1912. [The Ichneumonidae as beneficial or injurious insects]. Insect World 16: 494. (in Japanese).

Nawa, Y. 1913. [Hundred accounts of common beneficial insects]. Insect World 13: 328. (in Japanese).

Nozato, K. 1969. Biology of Ztoplectis cristutae Momoi (Hym., Ichneumonidae), a pupal parasite of the pine shoot moths in Japan. Kontyû 37 (1): 75-82. 
Ohmori, Y. 1960. [Hymenoptera from Kamo city, Niigata]. Essa Kontyū Dōkōkai Kaihō 9: 17. (in Japanese).

Ohgushi, R. 1959. The longevity, egg laying capacity and the number of hosts parasitized by one female of Mormoniella vitripennis(Walk,)(Hym., Pteromalidae) reared in three species of fly puparia. Insect Ecol. 8: 46-57. (in Japanese with English summary).

Ozaki, S. 1938. [Study on the ecology of the rice leaf-caterpillar, Naranga aenescens Moore]. Bull. Aichi-ken Agr. Exp. Sta. 1: 149-174. (in Japanese).

Peterson, A. 1953. A manual of entomological techniques. Edwards Bros., Ann Arbor, Mich. p. 47.

Quednau, W. 1960. Über die Indentität der Trichogramma-Arten und einiger ihrer Ökotypen (Hym., Chalcidoidea, Trichogrammatidae). Mitt. Biol. Bundesanstalt Land- u. Forstwirtsch. Berlin-Dahlem.

Sakai, K. et al. 1941. Studies on bionomics and control measures of Cnaphaiocrocis medinalis Guénée (Prelim. Rep.). Ōyö-Kontyü 4: 14. (in Japanese).

Salt, G. 1934. Experimental studies in insect parasitism, II. Superparasitism. Proc. R. ent. Soc. Lond. (B) 114: 455-476.

Salt, G. 1936. Experimental studies in insect parasitism. IV. The effect of superparasitism on populations of Trichogramma evanescens. Jour. Exp. Biol. 13: 363-375.

Salt, G. 1938. Experimental studies in insect parasitism. VI. Host suitability. Bull. Ent. Res. 29: 223-246.

Salt, G. 1940. Experimental studies in insect parasitism. VII. The effect of different hosts on the parasite Trichogramma evanescens Westw. (Hym., Chalcidoidea). Proc. R. ent. Soc. Lond. (A) 15: 81-95.

Schmiedeknecht, 0. 1907. Hymenoptera. Genera Insectorum 62: 36.

Shibuya, M. 1933. On the method of mass-production of Trichogramma. Proc. Imp. Acad., Tokyo 9 (3): 130-133.

Shiga, M. and Nakanishi, A. 1968. Intraspecies competition in a field population of Gregopimpla hymalayensis (Hym., Ichneumonidae) parasitic on M alacosoma neustria testacea (Lep., Lasiocampidae). Res. Popu. Ecol. 10: 69-86.

Short, J. R. T. 1959. A description and classification of the final instar larvae of the Ichneumonidae (Insecta, Hymenoptera). Proc. U. S. Nat. Mus. 110: 391-511.

Sonan, J. 1930. A few host-known Ichneumonidae found in Formosa (Hym.) (2). Trans. Nat. Hist. Hist. Soc. Formosa 20: 137. ("Sonan" is the former name for "Minamikawa")

Stern, V. M. et al. 1959. The integration of chemical and biological control of the spotted alfalfa aphid. I. The integrated control concept. Hilgardia 29 (2): 81101.

Subba Rao, B. R. 1955. Microbracon chinensis Szép. A short note on the technique of its mass-multiplication. Indian J. Ent. 17: 387-389.

Tsutsui, K. 1949. Effects of DDT and BHC on egg parasitic wasp of rice stem borer Trichogramma japonicum Ashmead. Ōyō-Kontȳ̄ 5 (2): 67-70. (in Japanese).

Townes, II. K. 1940. A revision of the Pimplini of Eastern North America (Hym., Ichneumonidae). Ann. Ent. Soc. Amer. 33: 314.

Townes, H. 1957. A review of the generic names proposed for old world Ichneumonids, the types of whose genotypes are in Japan, Formosa, or North America. Proc. Ent. Soc. Wash. 59: 113. 
Townes, H. 1958. Some biological characteristics of the Ichneumonidae(Hymenoptera) in relation to biological control. J. Econ. Entomol. 51: 650-652.

Townes, H. et al. 1965. A catalogue and reclassification of the Eastern Palearctic Ichneumonidae. Mem. Amer. Ent. Inst. 5: 40-41.

Uchida, T. 1928. Dritter Beitrag zur Ichneumoniden-fauna Japans. Jour. Fac. Agr. Hokkaido Imp. Univ. 25: 1-115.

Uchida, T. 1930. Beitrag zur Ichneumoniden-fauna Japans. Jour. Fac. Agr. Hokkaido Imp. Univ. 25: 357.

Uchida, T. 1956. Die Ichneumoniden aus der Amami Inselgruppe. Insecta Matsumurana 19: 91.

van den Bosch, R. and Stern, V. M. 1962. The integration of chemical and biological control of arthropod pests. Ann. Rev. Ent. 7: 367-386.

van Zwaluwenburg, R. H. 1929. Nesopimpla naranyae Ashm. Proc. Hawaii. Ent. Soc. 7(2): 226.

Watanabe, C. 1966. Notes on Braconid and Ichneumonid parasites of the rice stem borer, Chilo suppressalis (Walker), in Japan (Hymenoptera). Mushi 39: 98.

Wu, G. J. 1967. Life history observation and natural enemies survey of diamond back moth. Plant Protection Bulletin, Taipei 9: 88.

Wylie, H. G. 1962. An effect of host age on female longevity and fecundity in Nasonia vitripennis (Walk.) (Hym., Pteromalidae). Can. Ent. 94: 990-993.

Wylie, H. G. 1963. Some effects of host age on parasitism by Nasonin vitripennis (Walk.) (Hym., Pteromalidae). Can. Ent. 95: 881-886.

Wylie, H. G. 1964. Effect of host age on rate of development of Nasonia vitripennis (Walk.) (Hym., Pteromalidae). Can. Ent. 96: 1023-1027.

Yasumatsu, K. and Fukushima, I. 1945. Notes on some Hymenoptera parasitic on the larva of Naranga aenescens Moore. Mushi 16: 15. (in Japanese).

Yasumatsu, K. and Tachikawa, T. 1949. Investigation on the Hymenopterous parasites of Ceroplastes rubens Maskell in Japan. Jour. Fac. Agr. Kyushu Univ. 9 (2) : 99-120.

Yasumatsu, K. 1951. Further investigations on the Hymenopterous parasites of Ceroplastes rubens in Japan. Jour. Fac. Agr. Kyushu Univ. 10 (1): 1-27.

Yasumatsu, K. 1953. Some considerations on the reproductive capacity of a Kyushu race of Anicetus ceroplastis Ishii, an effective parasite of Ceroplastes rubens Maskell in Japan. Sci. Bull. Fac. Agr. Kyushu Univ. 14 (1): 7-15. (in Japanese with English summary).

Yasumatsu, K. and Yamamoto, S. 1953. Comparisons on the reproductive capacity among Anicetus ceroplastis Ishii reared from Ceroplastes rubens Maskell feeding on different host plants. Sci. Bull. Fac. Agr. Kyushu Univ. 14 (1): 27-33. (in Japanese with English summary).

Yasumatsu, K. and Watanabe, C. 1964. A tentative catalogue of insect natural enemies of injurious insects in Japan. 1: 46. Ent. Labor. Fac. Agr. Kyushu Univ., Japan.

Yasumatsu, K. 1964. The possible control of rice stem borers by the use of natural enemies. In: The major insect pests of the rice plant, pp. 431-442. The Johns Hopkins Press, Baltimore.

Yasumatsu, K. 1967. Distribution and bionomics of natural enemies of rice stem borers (research on the natural enemies of rice stem borers). Mushi 39, Suppl. : $33-44$. 
Yasumatsu, K. and Torii, T. 1968. Impact of parasites, predators and diseases on rice pests. Ann. Rev. Ent. 13: 295-324. 